\title{
The George C. Davis Site, Cherokee County, Texas: Spring 1980 Archeological Investigations
}

Ross C. Fields

Prewitt and Associates, Inc.

J. Peter Thurmond

Prewitt and Associates, Inc.

Follow this and additional works at: https://scholarworks.sfasu.edu/ita

Part of the American Material Culture Commons, Archaeological Anthropology Commons, Environmental Studies Commons, Other American Studies Commons, Other Arts and Humanities Commons, Other History of Art, Architecture, and Archaeology Commons, and the United States History Commons

Tell us how this article helped you.

This Article is brought to you for free and open access by the Center for Regional Heritage Research at SFA ScholarWorks. It has been accepted for inclusion in Index of Texas Archaeology: Open Access Gray Literature from the Lone Star State by an authorized editor of SFA ScholarWorks. For more information, please contact cdsscholarworks@sfasu.edu. 


\section{The George C. Davis Site, Cherokee County, Texas: Spring 1980 Archeological Investigations}

\section{Creative Commons License}

\section{(c) (1) $\Theta(9$}

This work is licensed under a Creative Commons Attribution-NonCommercial-No Derivative Works 4.0 International License. 
THE GEORGE C. DAVIS SITE, CHEROKEE COUNTY, TEXAS:

SPRING 1980 ARCHEOLOGICAL INVESTIGATIONS

\author{
by \\ Ross Fields \\ and \\ J. Peter Thurmond
}

PRINCIPAL INVESTIGATOR: Elton R. Prewitt

REPORTS OF INVESTIGATIONS, NUMBER 8

Prewitt and Associates, Inc. Consulting Archeologists

Austin, Texas

June 1980 
Report submitted to Texas Forest Service, Texas A\&M University system, College Station, Texas, under the terms of a Letter of Authorization dated April 1, 1980. Work reported herein was conducted under the terms of Antiquities Permit No. 237 issued by the Texas Antiquities Committee. 
TABLE OF CONTENTS

FOREWORD . . . . . . . . . . . . . . . . . . . V V

ABSTRACT •. . . . . . . . . . . . . . . . . . vi v v

ACKNOWLEDGMENTS • . . . . . . . . . . . . . . . . . vii

INTRODUCTION . . . . . . . . . . . . . . . . . . 1

INVESTIGATIONS . . . . . . . . . . . . . . . . . . 2

Objectives . . . . . . . . . . . . . 2

The Excavations . . . . . . . . . . . . 5

Field Procedures . . . . . . . . . . . 9

THE CULTURAL FEATURES . . . . . . . . . . . . . . 12

Discussion of Features . . . . . . . . . 12

CERAMICS .................... . . . 28

Non-Vessel Ceramics . . . . . . . . . . . 29

Vessel Ceramics . . . . . . . . . . . 31

Pre-Caddoan ............. . . 31

Early Caddoan . . . . . . . . . . . 31

Late Caddoan .......... . . . 34

Temporally Nondiagnostic Caddoan . . . . 39

Discussion of Ceramics . . . . . . . . . 45

LITHICS • . . . . . . . . . . . . . . . 48

Chipped Stone ............. . . 48

Tools •............... 48

Preforms . . . . . . . . . . . 61

Debitage ............. . . 62

Abraded, Pecked, and Battered stone : : . . - 74

Tools ............. 74

Flakes and Fragments ............78 78

Polished Stone . . . . . . . . . . . 78

Unmodified Pebbles ... . . . . . . . . 79

Discussion of Lithics . . . . . . . . . 79

HISTORIC ARTIFACTS • . . . . . . . . . . . . 83

FLORAL AND FAUNAL REMAINS . . . . . . . . . . . . 87

SUMMARY AND CONCLUSIONS • . . . . . . . . . . . . . 88

REFERENCES CITED . . . . . . . . . . . . . . . 93 


\section{LIST OF FIGURES}

1. Project location map . . . . . . . . . . . . . ix

2. Plan of Spring 1980 excavations . . . . . . . . . . 3

3. Plan of Spring 1980 excavations showing

general artifact densities . . . . . . . . 47

\section{LIST OF TABLES}

1. Excavation unit metric data summary . . . . . . . 7

2. Management unit and area of excavations summary - 8

3. Grid coordinates and arbitrary elevations of permanent data . . . . . . . . . . . . 10

4. Feature descriptions . . . . . . . . . . . 13

5. Provenience of non-vessel ceramics . . . . . . . 30

6. Provenience of pre-Caddoan ceramics . . . . . . . 32

7. Provenience of Early Caddoan vessel ceramics . . . . 33

8. Provenience of Late Caddoan vessel ceramics . . . 35

9. Provenience of temporally nondiagnostic Caddoan vessel ceramics . . . . . . . . . . 40

10. Provenience of chipped stone tools and preforms . 49

11. Provenience of chipped stone debitage (chert) . . 63

12. Provenience of chipped stone debitage (fine-grained quartzite) . . . . . . . . . 66

13. Provenience of chipped stone debitage (coarse-grained quartzite) .. . . . . . . . 69

14. Provenience of chipped stone debitage (silicified wood and other materials) . . . . . 71

15. Provenience of abraded, pecked, battered and polished stone . . . . . . . . . . . 75

16. Percentage of lithic debitage by raw material : . 81

17. Ranking of units by percentage of chert debitage . . 82

18. Provenience of historic artifacts, floral and faunal remains and unmodified pebbles . . . . 84

19. Projected artifact densities . . . . . . . . 90 


\section{FOREWORD}

The results of archeological investigations in portions of the George C. Davis Site are presented in this report prepared by Ross Fields and J. Peter Thurmond. Stringent contract requirements and the provisions of Texas Antiquities Permit No. 237 dictate that this report be brief and descriptive in nature. Requirements such as inclusion of a detailed site investigation history and environmental data were excluded and extensive excavations were stressed in preference to detailed analyses and comparisons. Field investigations were limited by contract to 20 working days and the analysis/write-up to 10 working days. The governing research design was prepared by the Texas Antiquities Committee staff to reflect agreements between the Committee and the Texas Forest Service.

Significant findings include the general delineation of extensive, and in places intensive, Archaic and Late Prehistoric occupations. Of primary importance is the lack of an identifiable Alto Focus occupation within the northern portion of the Davis Site. This suggests that the small left bank tributary to Bowles Creek existed during Alto Focus times and served as a natural boundary for the village area during that period of site usage. There are hints that significant variations in the selection and use of lithic resources through time are identifiable. It is indeed unfortunate that time limitations precluded pursuit of this line of investigation.

Ross and Pete have successfully accomplished a most challenging task under less than ideal conditions. They and their field crew are commended for their outstanding work at the Davis Site.

Elton R. Prewitt Principal Investigator 
Archeological investigations within the northern portion of the George C. Davis Site (41CE19), a major Alto Focus village and mound complex in Cherokee County, Texas, were carried out during Apriz and May 1980. This work was done by Prewitt and Associates, Inc. under a contract with the Texas Forest Service and conforms to the requirements of Texas Antiquities Permit No. 237.

An absence of Alto Focus artifacts and features suggests that a small tributary to Bowles Creek may have served as a northern boundary for the Alto Focus village. Areas of concentrated pre-Caddoan and Late Caddoan artifacts are identified on the basis of both ceramic and lithic artifacts. The highest intensity of pre-Caddoan and Late caddoan occupations are in Management Area 2 of the project area; this area overlooks Bowles Creek to the northwest and a smalz left bank tributary to the south.

It is recommended that Area 2 be reserved for further investigations and that Areas 1 and 3 be cleared for development as a seed bed as part of the expansion program at Indian Mound Nursery. 


\section{ACKNOWLEDGMENTS}

That this project was completed successfully, in fact that it was even undertaken at all, is a direct result of the efforts of a number of individuals who have a very real concern for and dedication to preserving and understanding our cultural resources. First and foremost among these, from the field archeologist's point of view, are the members of the field crew: Darrell Creel, Gene Davis, Mike Davis, Will Day, Bill Driggers, Molly Godwin, Jan Guy, Jane Laurens, Jerri McLerran, Jody Pevey and Pete Thurmond. Pete Thurmond deserves special credit for organizing and running the field laboratory and for providing the body of the artifact analysis. That this fine crew was assembled is the direct responsibility of Elton $\mathrm{R}$. Prewitt, the Principal Investigator for this project; Elton is thanked for his advice both in the field and in the write-up, for his editing of this report, and for his desire that the archeology be done well. A very special thanks goes to Sharon WagnerHubbard who volunteered two-and-one-half weeks of her time to assist with artifact cataloging and sorting.

Special thanks also go to LaVerne Herrington of the Texas Antiquities Committee for her unceasing efforts to insure that quality work be done at the Davis site, and to LaVerne and Dee Ann Story for valuable advice during the excavations.

The Texas Forest Service, a unit of the Texas A\&M University System, funded the excavations; the funding and the assistance given by Paul R. Kramer, Director, are grealty appreciated. I also express my gratitude to Harold Lovell and all of his employees at the Indian Mound Nursery for providing housing and power machinery, and for being gracious hosts during our stay in Cherokee County. 
The fieldwork was helped to completion by a large number of people who volunteered from one hour to four days of their time. Alphabetically, these are: Rick Acolla, Cindy Banks, Wayne Boggs, Kimberly Davis, Sharon Davis, Lee Guy, LaVerne Herrington, Rick Hubbard, Ulrich Kleinschmidt, Peggy Leshikar, Max Morris, Neal Morris, Rodney Steele, Dee Ann Story, Steve Thurmond, Susie Thurmond and Nancy Wade.

During the write-up phase, valuable assistance was lent by Linda Nance in typing and editing, Jerri. McLerran in making provenience tables and measuring artifacts, and Steve Kotter in helping to identify faunal remains.

Much of this report was written while the excavations were in progress. Pete Thurmond classified and described the artifact collections; most of what he wrote (especially the descriptions of the ceramics, chipped stone debitage, and abraded, pecked, battered and polished stone) appears with little, if any, modification in this report. The senior author wrote drafts of the first two chapters and most of the third chapter while still in the field; the remainder of the report was completed in Austin between May 27 and June 6, 1980 .

To all of the people mentioned above, I express my sincere gratitude and respect.

$$
\begin{aligned}
& \text { Ross Fields } \\
& \text { June 6, } 1980
\end{aligned}
$$




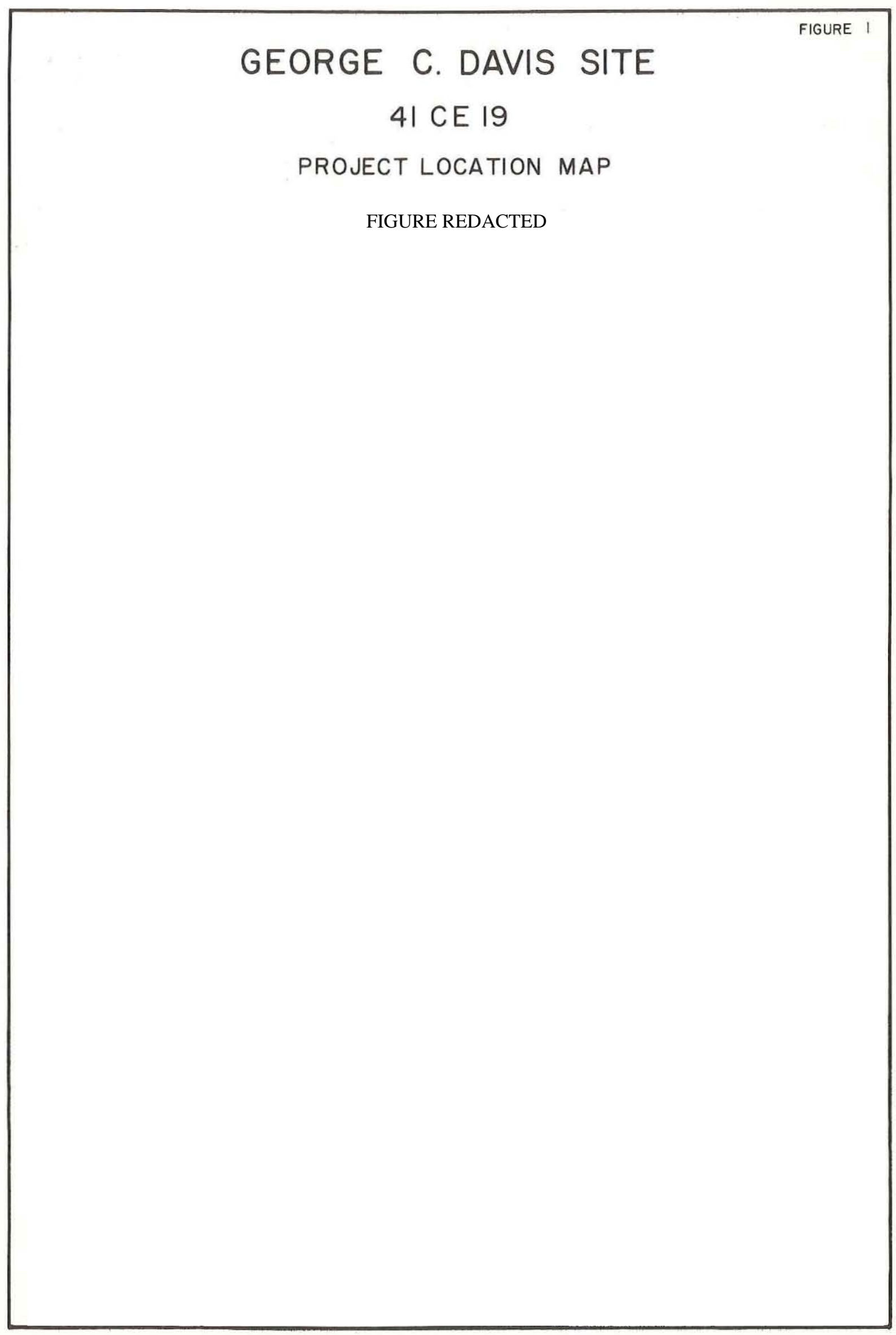




\section{INTRODUCTION}

This report describes archeological investigations carried out from April 28 to May 23, 1980, at the George C. Davis Site (41CE19), Cherokee County, Texas. The portions of the site investigated lie on lands owned by the Texas Forest Service, a unit of the Texas A\&M University System; the property is slated for intensive development during the summer of 1980 as part of an expansion program at Indian Mound Nursery.

The Davis Site, which prior to 1980 had been professionally investigated by The University of Texas-Works Progress Administration in 1939-1941 (Newell and Krieger 1949), The University of Texas at Austin in 1968-1970, 1977, 1978 and 1979 (Story 1972; Fields 1978; Thurmond and Kleinschmidt 1979)), and Texas A\&M University in 1978 (Creel 1979), lies on a high terrace east of the Neches River. The primary component relates to an early Caddoan, or Alto Focus, occupation although both pre-Caddoan and Late Caddoan (Newell and Krieger 1949: 191-192; Creel 1979: 110, 149-150) components are represented. The main surface features at the site, three earthen mounds designated A, B and C, were constructed during the Alto Focus occupation (Story and Valastro 1977).

While a significant portion of the site is included within the Caddoan Mounds state Historic Site, a large part of the village area is on land owned by the Texas Forest Service, Indian Mound Nursery. Recently acquired and as yet undeveloped nursery lands north and northeast of the State Historic Site were the subject of the 1978 Texas A\&M investigations (Creel 1979). The excavations reported on here were concentrated on portions of the recent Texas Forest Service acquisition which were not sampled in Creel's excavations (Fig. 1). 
The Spring 1980 investigations were conducted under terms of a contract between the Texas Forest Service and Prewitt and Associates, Inc., Consulting Archeologists, and under the provisions of Antiquities Permit No. 237 issued by the Texas Antiquities Committee. The Principal Investigator was Elton R. Prewitt, and the fieldwork was carried out in twenty work-days by an eleven-member crew (supplemented with considerable volunteer help) under the supervision of Ross Fields.

Due to budgetary and other contract limitations, this report is almost entirely descriptive. Included are a discussion of the objectives and field methods used, a description of the cultural features encountered, a description of the artifacts recovered, and a statement on how data generated through these investigations relate to previous concepts concerning the Davis Site.

\section{INVESTIGATIONS}

\section{Objectives}

The goals of this investigation were stated in a Research Design developed by the Texas Antiquities Committee and subsequently included within the governing contract; they were "1) to identify areas of high cultural content which will be set aside for investigation by field schools; and 2) to clear the maximum area for seed bed utilization."

Prior to the field work, the Texas Antiquities Committee in consultation with the Texas Forest Service divided the project area (Fig. 2) into three management units (Areas 1-3). The Antiquities Committee Research Design specified that: 


\section{GEORGE C. DAVIS SITE}

41 CE 19

PLAN OF EXCAVATIONS

FIGURE REDACTED 
"Investigation will be thorough in area 1 , so that at the completion of fieldwork this area can be utilized for seed bed construction. Investigation of areas 2 and 3 will be sufficient to determine:

1) if either area merits further investigation, and, if so, tial, and

2) which area has the higher research poten-

3) which area (either 2 or 3) should be set aside for investigation by field schools. When this has been determined then either area 2 or 3 will be investigated further so that the area can be utilized for seed beds upon the completion of fieldwork, and work will cease in the area to be investigated by field schools.

4) in the event that testing of area 1 reveals the area contains archeological materials for which an adequate sample cannot be recovered by placement of units as described below, then the Texas Antiquities Committee in consultation with the Texas Forest Service and the field archeologist will develop a research design for area 1."

These investigations, then, were originally conceived of and outlined in the Research Design as involving testing of Areas 1, 2 and 3; mitigation of the loss of Area 1 and either Area 2 or 3; and the reservation of either Area 2 or 3 for later investigation by field schools. However, this plan was predicated on the existence within the project area of abundant cultural remains relating to the primary occupation (Alto Focus) of the Davis Site. The University of Texas Field Schools, under agreement with the Texas Parks and Wildlife Department, were to conduct investigations within the project area, which is outside of the state Historic Site, only if those investigations would further 
an understanding and interpretation of the prehistory of the Caddoan Mounds State Historic Site.

Early in these investigations it was discovered that the project area does not contain abundant Alto Focus remains; instead, it was found the area was occupied primarily before and after Alto Focus times. This discovery prompted a consultation between LaVerne Herrington of the Texas Antiquities Committee, Dee Ann Story of The University of Texas at Austin, and the field archeologist wherein it was decided that:

The 1980 University of Texas at Austin Field School would not be able to justify conducting investigations within the project area; but (2) Areas 2 or 3 would be held for investigations by other field schools until October 1, 1982, in accordance with the Memorandum of Agreement between the Texas Forest Service and the Texas Antiquities Committee.

Given the uncertainty of the situation, however, our objectives were broadened to include testing and mitigation of all three management units (Areas 1-3) within the project area. While mitigation measures were implemented, inclement weather during the final two weeks of fieldwork and the great size of the site prevented the excavation of large enough areas to provide a full understanding of the history and internal structure of this portion of the Davis site.

\section{The Excavations}

The method of investigation used in this project is one which was outlined in the Antiquities Committee Research Design and which has been shown to be effective in previous investigations at the site (Story 1972; Fields 
1978; Creel 1979; Thurmond and Kleinschmidt 1979). Specifically, it involves the excavation of areas (excavation units) of sufficient size to produce reliable data on artifact densities and the presence or absence of cultural features.

The Research Design, following the practice of previous investigations (Fields 1978; Creel 1979), specified that these excavation units should be an arbitrary $8 \times 6$ meters in size. Further, it stated that at least ten of these units should be excavated in Area 1, two in Area 2 and three in Area 3.

Once in the field, however, it was decided that the use of smaller excavation units would provide information comparable to that yielded by $8 \times 6$-meter units and would allow more rapid sampling of the project area. Thus, for this project the most commonly used excavation unit was $4 \mathrm{x} 6$ meters in size (Table 1). A total of 42 units were fully excavated.* Twenty-three of these measured $4 \times 6$ meters, fifteen were $2 \times 6$ meters, two were $8 \times 6$ meters, one was $4 \times 3$ meters and one was $8 \times 2$ meters (see Table 1). Table 2 provides a summary of the number of units excavated, the equivalent number of $6 \times 8$-meter units, the areas of management units and excavations, and the percentage of the project area sampled.

The placement of excavation units was guided by the need to: (1) determine the extent and density of cultural remains across the entire project area; and (2) relatively intensively investigate portions of the area which were found to contain high densities of cultural remains. Units

*one 2x6-meter unit (Unit 95) was opened but not completed due to heavy rains and tractor disturbance. 
TABLE 1

EXCAVATION UNIT METRIC DATA SUMMARY

\begin{tabular}{|c|c|c|c|c|}
\hline Unit & Dimensions (m) & $\begin{array}{c}\text { Area } \\
\text { Excavated }\left(\mathrm{m}^{2}\right) *\end{array}$ & $\begin{array}{l}\text { Average } \\
\text { Depth }(\mathrm{m})\end{array}$ & Volume $\left(\mathrm{m}^{3}\right)$ \\
\hline 66 & $6 \times 4$ & 20.56 & 0.39 & 8.02 \\
\hline 67 & $6 \times 4$ & 22.01 & 0.32 & 7.04 \\
\hline 68 & $6 \times 8$ & 44.61 & 0.25 & 11.15 \\
\hline 69 & $6 \times 8$ & 41.00 & 0.22 & 9.04 \\
\hline 70 & $6 \times 4$ & 21.65 & 0.23 & 4.98 \\
\hline 71 & $6 \times 4$ & 17.79 & 0.32 & 5.69 \\
\hline 72 & $6 \times 4$ & 19.15 & 0.19 & 3.64 \\
\hline 73 & $4 \times 3$ & 9.45 & 0.11 & 1.04 \\
\hline 74 & $6 \times 4$ & 22.25 & 0.30 & 6.67 \\
\hline 75 & $6 \times 4$ & 23.80 & 0.24 & 5.71 \\
\hline 76 & $6 \times 4$ & 20.39 & 0.44 & 8.97 \\
\hline 77 & $6 \times 4$ & 19.11 & 0.21 & 4.01 \\
\hline 78 & $6 \times 4$ & 17.16 & 0.22 & 3.78 \\
\hline 79 & $6 \times 4$ & 18.22 & 0.23 & 4.19 \\
\hline 80 & $6 \times 4$ & 20.43 & 0.43 & 8.78 \\
\hline 81 & $6 \times 4$ & 22.40 & 0.27 & 6.05 \\
\hline 82 & $6 \times 4$ & 19.20 & 0.33 & 6.34 \\
\hline 83 & $6 \times 4$ & 22.57 & 0.20 & 4.51 \\
\hline 84 & $6 \times 4$ & 22.37 & 0.31 & 6.93 \\
\hline 85 & $6 \times 4$ & 19.73 & 0.28 & 5.52 \\
\hline 86 & $6 \times 4$ & 18.10 & 0.35 & 6.33 \\
\hline 87 & $6 \times 4$ & 19.95 & 0.15 & 2.99 \\
\hline 88 & $6 \times 4$ & 21.50 & 0.17 & 3.65 \\
\hline 89 & $6 \times 4$ & 19.12 & 0.21 & 4.02 \\
\hline 90 & $6 \times 4$ & 20.10 & 0.28 & 5.63 \\
\hline 91 & $6 \times 2$ & 13.22 & 0.24 & 3.17 \\
\hline 92 & $6 \times 2$ & 12.69 & 0.25 & 3.17 \\
\hline 93 & $6 \times 2$ & 11.98 & 0.25 & 2.99 \\
\hline 94 & $6 \times 2$ & 11.83 & 0.26 & 3.08 \\
\hline 95 & $6 \times 2$ & - & - & - \\
\hline 96 & $6 \times 4$ & 22.64 & 0.35 & 7.92 \\
\hline 97 & $6 \times 2$ & 11.34 & 0.36 & 4.08 \\
\hline 98 & $6 \times 2$ & 10.65 & 0.43 & 4.58 \\
\hline 99 & $6 \times 2$ & 11.15 & 0.46 & 5.13 \\
\hline 100 & $6 \times 2$ & 10.64 & 0.41 & 4.36 \\
\hline 101 & $6 \times 2$ & 9.98 & 0.43 & 4.29 \\
\hline 102 & $6 \times 2$ & 10.67 & 0.28 & 2.99 \\
\hline 103 & $6 \times 2$ & 14.24 & 0.25 & 3.56 \\
\hline 104 & $6 \times 2$ & 10.73 & 0.25 & 2.68 \\
\hline 105 & $6 \times 2$ & 9.28 & 0.25 & 2.32 \\
\hline 106 & $8 \times 2$ & 14.58 & 0.27 & 3.94 \\
\hline 107 & $6 \times 2$ & 10.62 & 0.21 & 2.23 \\
\hline 108 & $6 \times 2$ & 10.37 & 0.54 & 5.60 \\
\hline
\end{tabular}

*These figures are less than areas of units as laid out because an entire unit was seldom completely excavated. 
TABLE 2

MANAGEMENT UNITS

\begin{tabular}{|c|c|c|c|c|}
\hline & Area 1 & Area 2 & Area 3 & Total \\
\hline $\begin{array}{l}\text { Area of } \\
\text { Management } \\
\text { Unit }\end{array}$ & $\begin{array}{l}10.25 \text { hectares } \\
(26.33 \text { acres })\end{array}$ & $\begin{array}{l}2.22 \text { hectares } \\
(5.49 \text { acres })\end{array}$ & $\begin{array}{l}1.15 \text { hectares } \\
(2.83 \text { acres })\end{array}$ & $\begin{array}{l}13.62 \text { hectares } \\
(33.65 \text { acres })\end{array}$ \\
\hline $\begin{array}{l}\text { Number of } \\
\text { Units } \\
\text { Excavated }\end{array}$ & 29 & 10 & 3 & 42 \\
\hline $\begin{array}{l}\text { Equivalent } \\
\text { Number of } \\
8 \times 6 \text { Units }\end{array}$ & 12.08 & 3.75 & 2.00 & 17.83 \\
\hline $\begin{array}{l}\text { Area of } \\
\text { Excava- } \\
\text { tions* }\end{array}$ & 504.54 & 159.79 & 84.98 & 749.31 \\
\hline $\begin{array}{l}\text { Percentage } \\
\text { of Manage- } \\
\text { ment Unitt } \\
\text { Sampled }\end{array}$ & $0.49 \%$ & $0.72 \%$ & $0.74 \%$ & $0.55 \%$ \\
\hline
\end{tabular}


$66-90,96,107$ and 108 were excavated to sample the project area, while Units 91-94 and 97-106 were placed to increase coverage in areas of special interest. Portions of the project area $(e . g .$, in the vicinities of Units 96 and Units 73, 88 and 107) should have been more intensively investigated, but a lack of time prevented further examinations.

\section{Field Procedures}

The field procedures followed in these investigations are essentially the same as those used previously at the site (Fields 1978; Creel 1979; Thurmond and Kleinschmidt 1979) and will be discussed only briefly here.

Excavation units were established by using the right triangle-hypotenuse method along or close to arbitrary grid lines; these grid lines were established with the aid of a transit and were derived from a north-south grid line (the W1095 line) which was extended onto the project area from the previously established grid used in excavations on the Caddoan Mounds State Historic Site and in the 1978 Texas A\&M University excavations. The grid, oriented to magnetic north, was extended onto the project area by a Texas Parks and Wildlife Department surveyor using a theodolite with a laser rangefinder. The Parks and Wildlife Department surveyor also set five relatively permanent markers with grid coordinates and arbitrary elevations coordinated with the vertical reference system used in previous investigations at the site (Table 3 ). 
TABLE 3

GRID COORDINATES AND ARBITRARY ELEVATIONS OF PERMANENT DATA

\begin{tabular}{clc}
\hline Datum \# & Grid Coordinates & Arbitrary Elevation \\
\cline { 2 - 3 } 1 & N1326.524/W1095.000 & $99.323 \mathrm{~m}$ \\
2 & N1535.842/W1095.000 & $100.369 \mathrm{~m}$ \\
3 & N1572.342/W1095.000 & $100.579 \mathrm{~m}$ \\
4 & N1535.842/W865.985 & $100.119 \mathrm{~m}$ \\
5 & N1326.524/W1270.169 & $98.583 \mathrm{~m}$ \\
\hline
\end{tabular}

Surface collection prior to excavation was attempted only in the first unit (Unit 66) and then abandoned since the entire project area was blanketed by thick groundobscuring growths of clover, crown vetch and various grasses. Most of the plow zone (usually the upper $20-30 \mathrm{~cm}$ of soil) was removed from each unit using a tractor equipped with a front-end loader. When done carefully, the power machinery left flat and fairly level floors requiring a minimum of shovel clearing. After blading in the plow zone, excavation unit floors were generally shoveled to a level just below the deepest plow disturbance. Floors were then carefully troweled and examined for cultural features.

Disturbances which were visible after the initial troweling and which were thought to be possibly cultural in origin were first probed using a one-and-one-half inch diameter soil probe. Those which, after probing, were still regarded as possibly cultural in origin were then usually cross-sectioned to provide a profile view of the feature. In some cases (usually obvious historic features) probing constituted the only investigation of cultural features. 
A few features were investigated by removal of the fill rather than cross-sectioning. Most disturbances which were thought to be cultural or were investigated beyond the initial probing were given feature and subfeature numbers. All designated features within a single unit, or set of contiguous units, were given the same feature number with separate subfeature numbers $(e \cdot g \cdot$, Unit 66 contained eight investigated disturbances, F198-1 through F198-8).

Approximately $40 \%$ of the backdirt from most units was screened through one-quarter-inch mesh hardware cloth. This task was somewhat facilitated by the use of water pumped from a water trailer provided by the Indian Mound Nursery. Backdirt from each unit was placed in three piles: front-end loader removed sod and upper plow zone; (2) front-end loader removed lower plow zone; and (3) soil removed in shoveling the unit floor. Generally, the visusally estimated percentage (usually 40\%) of plow zone to be screened was taken from, the latter two piles loften both piles were entirely screened). In view of the many years of cultivation and the sandy nature of the soil in the project area, it seems unlikely that failure to screen the upper plow zone will produce significant biases in artifact recovery.

All of the sequence numbers (excavation units, features, artifact lots, matrix samples, and photograph catalog numbers) used in these investigations were continued from previous excavations at the site and, as noted, the horizontal and vertical reference systems used were extended from previous excavation areas. All notes, photographs, other documents and the artifacts recovered remain the property of the State of Texas and will be housed at the 
Texas Archeological Research Laboratory, The University of Texas at Austin.

\section{THE CULTURAL FEATURES}

Of the 73 disturbances investigated and given feature numbers during these excavations, 37 were deemed to be noncultural in origin. The remaining 36 disturbances have been classified as definitely or possibly cultural. The primary criteria used in assigning a definitely or possibly cultural origin to these features are regular shape and size, nature of fill (i.e., not recent plow zone fill), presence of artifacts, charred floral or faunal remains, or burned clay, and proximity to other suspected cultural features. As noted in other reports (Creel 1979: 23; Thurmond and Kleinschmidt 1979: 5-6), the assessment of disturbances at this site is sometimes problematical, and thus it is necessary to label some disturbances as "possibly cultural."

The definitely and possibly cultural features can be separated into two groups: aboriginal and historic (probably modern). The cultural features are assigned to general morphological categories (Table 4); however, the functions of the aboriginal features remain a mystery. Functions are suggested for the historic features, but these interpretations remain open to question.

\section{Discussion of Features}

Only nine of the 36 definite or possible cultural features appear to be aboriginal in origin; 26 appear to be historic; and one may be either aboriginal or historic. 
TABLE 4

FEATURE DESCRIPTIONS

Feature
No. Unit

197-1 $66 \quad$ Vaguely defined superficial stain; less than $5 \mathrm{~cm}$

in depth; no artifacts or charcoal noted in fill.

Noncultural

97-2 66 Shallow, circular disturbance $(25 \times 22 \times 3 \mathrm{~cm}$.$) * with very$ irregular shape in profile; fill contained one flake.

197-3 66 Shallow, semi-circular disturbance (16 × $7 \times 2 \mathrm{~cm}$.); no artifacts or charcoal in fil1.

Circular disturbance $(30 \times 30 \times 21 \mathrm{~cm}$.) with much rodent disturbance in upper half; margins in lower half quite distinct; ca. $1 \mathrm{~cm}$. thick band of yellow sand along the bottom; disturbed upper portion contained several charred nutshell fragments, a charred bone fragment, several tiny flecks of charcoal and one flake.

$197-5$

Vaguely defined oval disturbance $(21 \times 19 \times 15 \mathrm{~cm}$.) with very irregular outline and much rodent disturbance; fill contained one sherd.

$197-6$

Irregularly-shaped disturbance $(24 \times 23 \times 17 \mathrm{~cm}$.) with much rodent disturbance; no artifacts in fi11; a few charcoal flecks noted in upper $5 \mathrm{~cm}$.

Noncultural

Noncultura 1, rodent burrow

Possibly cultural; aboriginal pit (based on shape, distinct margins, nature of fi 11 and inclusions)

Noncultural

Noncultura 1, rodent burrow

*First two measurements are dimensions at detection leve1; third is the maximum depth below detection level. 
TABLE 4, Continued.

\begin{tabular}{|c|c|c|c|}
\hline $\begin{array}{c}\text { Feature } \\
\text { No. }\end{array}$ & Unit & Description & Assessment \\
\hline $197-7$ & 66 & $\begin{array}{l}\text { Irregularly-shaped disturbance }(19 \times 19 \times 18 \mathrm{~cm} .) \text { with } \\
\text { vague margins and disturbed fil1; no artifacts or charcoal } \\
\text { noted in fill. }\end{array}$ & Noncultural \\
\hline $197-8$ & 66 & $\begin{array}{l}\text { Circular area }(20 \times 20 \times \text { ? cm.) marked by slightly more } \\
\text { compact soil; no evidence of disturbance seen in profile. }\end{array}$ & Noncultural \\
\hline $198-1$ & 68 & $\begin{array}{l}\text { Shallow circular disturbance }(27 \times 26 \times 8 \mathrm{~cm} .) \text { with } \\
\text { irregular basal margin and irregular shape in profile; } \\
\text { no artifacts or charcoal in fill. }\end{array}$ & $\begin{array}{l}\text { Noncultural, probable } \\
\text { rodent burrow }\end{array}$ \\
\hline $198-2$ & 68 & $\begin{array}{l}\text { Shallow irregularly-shaped disturbance }(25 \times 30 \times 10 \mathrm{~cm} .) \\
\text { resembling F198-1; no artifacts or charcoal noted. }\end{array}$ & $\begin{array}{l}\text { Noncultura 1, probable } \\
\text { rodent burrow }\end{array}$ \\
\hline 198-3 & 68 & $\begin{array}{l}\text { Superficial circular area }(15 \times 17 \mathrm{~cm} \text {.) with slight } \\
\text { textural difference from surrounding matrix; no evidence } \\
\text { of disturbance seen in profile. }\end{array}$ & Noncultural \\
\hline $198-4$ & 68 & $\begin{array}{l}\text { Circular disturbance }(23 \times 25 \times 30 \mathrm{~cm} \text {. }) \text { containing yellow } \\
\text { sand partially surrounded by a ring of disturbed orange } \\
\text { clay; soil probe showed that orange clay ring overlay } \\
\text { yellow sand; some wash noted in fill; no artifacts or } \\
\text { charcoal noted. }\end{array}$ & $\begin{array}{l}\text { Cultural, modern auger } \\
\text { hole (?) (based on } \\
\text { nature and arrangement } \\
\text { of fills) }\end{array}$ \\
\hline $198-5$ & 68 & $\begin{array}{l}\text { Shallow circular disturbance }(34 \times 32 \times 10 \mathrm{~cm} \text {.) containing } \\
\text { recent plow zone fill; margins distinct; no artifacts or } \\
\text { charcoal noted in fill. }\end{array}$ & $\begin{array}{l}\text { Possibly cultural } \\
\text { (based on shape and } \\
\text { distinct margins); } \\
\text { modern pit (?) (based } \\
\text { on plow zone fill) }\end{array}$ \\
\hline
\end{tabular}


TABLE 4, Continued.

Feature
No. Unit Description Assessment

198-6 68 Two irregularly-shaped, adiacent areas (120 x $67 \times$ ? cm. and $25 \times 27 \times$ ? $\mathrm{cm}$.) with very compact soi 1 ; depth of compact soil undetermined; no artifacts or charcoal noted.

199-1 69 Roughly circular conical disturbance $(45 \times 37 \times 31 \mathrm{~cm}$. containing recent plow zone fill with red sandy clay; margins distinct; no artifacts or charcoal noted in fil1.

Possibly cultural, modern (may be soil compacted in construction of artificial terrace adjacent to this feature)

\section{Noncultura 1}

Roughly circular, conical disturbance $(30 \times 34 \times 29 \mathrm{~cm}$.) containing recent plow zone fi11; margins distinct but irregular; no artifacts or charcoal in fill.

$199-3$

$199-4$

69

$200-?$
Irregularly-shaped disturbance (31 × $47 \times 32+\mathrm{cm}$.) containing recent plow zone fill and numerous rodent burrows; no artifacts or charcoal noted in fill.

Superficial, roughly circular disturbance $(21 \times 19 \times 4 \mathrm{~cm}$.) containing recent plow zone fil1; no artifacts or charcoal noted.

71 Circutar, basin-shaped disturbance $(26 \times 26 \times 11 \mathrm{~cm}$.) containing dark brown fil1 with numerous rootlets; margins distinct; some root disturbance; no artifacts or charcoal in fill.

\section{Noncultura 1}

Noncultura 1, probable rodent burrow

Noncultural

Cultural, possible aboriginal pit (based on shape, distinctness of margins, nature of fill and proximity to other features) 
TABLE 4, Continued.

$\begin{array}{lll}\begin{array}{l}\text { Feature } \\ \text { No. Unit }\end{array} & \text { Description } & \text { Assessment }\end{array}$

200-2 $71 \quad \begin{aligned} & \text { Roughly circular, conical disturbance }(22 \times 18 \times 12 \mathrm{~cm} .) \\ & \text { containing dark brown fi } 11 \text { mottled with red sandy } 10 \text { am; }\end{aligned}$
margins distinct; no artifacts or charcoal noted in fill.

Possibly cultural, aboriginal pit (based on similarities and proximity to $\mathrm{F} 200-1$ and 3)

200-3 $71 \quad$ Roughly circular, basin-shaped disturbance $(35 \times 37 \times 17 \mathrm{~cm}$. containing dark brown fill with numerous rootlets; margins distinct; some rodent disturbance; no artifacts or charcoal noted in fill.

Vaguely defined, somewhat circular disturbance $(39 \times 51 \times$. $35+\mathrm{cm}$.) which tapers sharply to at least $35 \mathrm{~cm}$. below detection level where it is intersected by lateral, linear disturbance containing similar fill; much rodent disturbance; margins vague to distinct; no artifacts or charcoal noted in fill.

Very irregularly-shaped dark area $(44 \times 30 \times 120 \mathrm{~cm}$.) extensively churned by rodent burrows; margins very vague; charcoal noted in fil1; probing revealed hollow cavity at $75 \mathrm{~cm}$. below detection level.

Cultural, possible on shape, distinctness of margins, nature of fill and proximity to other features)

Noncultural, probable root mold number assigned for photographic reference.

Noncultura1, rodent burrow

Noncultural 
TABLE 4, Continued.

Feature
No. Unit

\begin{tabular}{llll}
\hline $201-3$ & Circular, basin-shaped disturbance $(27 \times 27 \times 19 \mathrm{~cm})$. & Cultural, historic \\
& containing greenish-gray fill; margins distinct; one & tree-planting hole
\end{tabular}

202-1

74 Irregularly-shaped disturbance $(34 \times 27 \times 10 \mathrm{~cm}$.) containing

Noncultural recent plow zone fill; margins distinct; no charcoal or artifacts noted.

202-2 74 Shallow circular disturbance $(30 \times 30 \times 7 \mathrm{~cm}$. $)$ containing rodent and root disturbances; margins distinct; no artifacts or charcoal in the fill.

203-1 75 Oval, basin-shaped disturbance $(29 \times 23 \times 9 \mathrm{~cm}$. $)$ containing greenish-gray fi11; margins fairly distinct; no artifacts or charcoal found in fill.

203-2 75 Concentration of hematite $(50 \times 60 \mathrm{~cm}$.); no pit visible; no evidence of in situ burning; surrounding fill contained 2 flakes but no charcoal.

203-3
Circular, basin-shaped disturbance $(23 \times 25 \times 10 \mathrm{~cm}$.) containing greenish-gray fi11; margins fairly distinct although disturbed by rodents and insects; no artifacts or charcoal in fill.
Circular disturbance $(31 \times 30 \times 12 \mathrm{~cm}$.) containing greenishgray fi11; margins distinct; no charcoal or artifacts noted.
Noncultural

Cultural, historic tree-planting hole (?)

Cultural, probable aboriginal hematite concentration (unknown function)

Cultura 1, historic tree-planting hole (?)

Cultural, historic tree-planting hole 
TABLE 4, Continued.

Feature
No. Unit Description

203-5 $76 \quad$ Circular disturbance $(31 \times 30 \times 10 \mathrm{~cm}$.$) containing greenish-$ gray fi11; margins vague; much rodent disturbance; no artifacts or charcoal noted.

204-1 76 Circular, basin-shaped disturbance $(29 \times 25 \times 12 \mathrm{~cm}$. containing recent plow zone fill with five distinct wash lenses and margins extremely distinct; no artifacts or charcoal in the fill.

204-2 $76 \quad$ Small concentration of burned clay lumps $(22 \times 12 \mathrm{~cm}$.$) ;$ no pit visible; no evidence of in situ burning; no artifacts or charcoal associated.

205-1

205-2

206-1
Small, shallow, roughly circular disturbance $(15 \times 19 \times 4$ $\mathrm{cm}$. ) containing ashy fill and charcoal; fill contained three wire nails.

7 Shallow, oval disturbance $(26 \times 18 \times 10 \mathrm{~cm}$.) containing ashy fill and charcoal; fill contained five wire nails and one cut nail.

Roughly circular disturbance $(20 \times 15 \times 18 \mathrm{~cm}$.) tapering gently towards the bottom; outline somewhat irregular; some gopher and root disturbance; no artifacts or charcoal noted in fill.
Cultural, historic tree-planting hole?

Cuitural, modern pit of unknown function

Cultural, may be aboriginal or historic; may represent highly disturbed area of limited burning

Cultural, modern posthole?

Cultural, modern modern posthole?

Noncultura 1 
TABLE 4, Continued.

Feature
No. Unit

207-1 $81 \quad$ Circular, basin-shaped disturbance $(35 \times 35 \times 16 \mathrm{~cm}$. $)$

containing fill rich in woody charcoal; margins distinct; fill contained one wire nail; closely resembles $\mathrm{F} 207-2,3,4$.

207-2 81 Circular disturbance $(30 \times 30 ? \times 15 \mathrm{~cm}$. $)$ containing fill rich in woody charcoal; margins distinct; no artifacts in fil1; closely resembles F207-1,3,4.

207-3 81 Circular disturbance $(30 \times 32 \times 15 \mathrm{~cm}$.) containing fill rich in woody charcoal; margins distinct; no artifacts noted; closely resembles F207-1,2,4.

207-5

208-1
Circular disturbance $(30 \times 28 \times 11 \mathrm{~cm}$.) containing fill rich in woody charcoal; margins distinct; no artifacts noted; closely resembles F207-1,2,3.

Shallow, circular disturbance $(30 \times 36 \times 5 \mathrm{~cm}$.); margins quite vague in profile; no artifacts in fill; small charcoal flakes noted in fill.

Roughly circular disturbance $(20 \times 19 \times 12 \mathrm{~cm}$.) with irregular shape in profile; margins distinct; no artifacts or charcoal in the fill.

Roughly circular disturbance $(44 \times 40 \times 27 \mathrm{~cm}$.) containing recent plow zone fill and woody charcoal; margins vague; no artifacts in fill.
Cultura1, modern structural footing?

Cultural, modern structural footing?

Cultural, modern structural footing?

Cultural, modern structural footing?

Noncultural

Noncultural

Noncultura 1 
TABLE 4, Continued.

Feature
No. Unit

210-1 85 Shallow, circular disturbance $(22 \times 23 \times 10 \mathrm{~cm}$.$) which$ tapers sharply towards the bottom; margins very vague; no artifacts or charcoal in the fill.

Noncultural, root mold

210-2 85 Circular, basin-shaped disturbance $(25 \times 25 \times 15 \mathrm{~cm}$. $)$; margins rather vague; no artifacts or charcoal in fill.

210-3 $85 \quad$ Superficial, circular disturbance $(28 \times 23 \times 1 \mathrm{~cm}$. $)$ with very indistinct margins; no disturbance seen in profile; no artifacts or charcoal noted.

Circular, basin-shaped disturbance $(27 \times 26 \times 12 \mathrm{~cm}$.) containing greenish-gray fil1; margins distinct; no artifacts or charcoal in fill.

211-2 87 Irregularly-shaped tapering disturbance $(33 \times 24 \times 23+$ cm.); margins distinct; no artifacts or charcoal in fill.

212-1 $88 \quad$ Large, roughly oval disturbance $(37 \times 100 \times 47 \mathrm{~cm}$.$) ;$ margins very vague; charcoal flakes, a few lumps of burned clay, a few flakes noted in fill.

213-1 97 Circular disturbance $(25 \times 29 \times 32+\mathrm{cm}$. $)$ containing very loose, dark brown fill; very irregular outline in profile; no artifacts or charcoal noted.

214-1 91 Irregular, tongue-shaped disturbance $(16 \times 23+\times 6 \mathrm{~cm}$. $)$; margins very indistinct; small charcoal flakes noted in

Possibly cultural, aboriginal pit

Noncultural

Cultural, historic tree-planting hole?

Noncultural, root mold

Possibly cultural, aboriginal pit (unknown function)

Noncultural fill and surrounding matrix.

Noncultural 
TABLE 4, Continued.

\begin{tabular}{|c|c|c|c|}
\hline $\begin{array}{l}\text { Feature } \\
\text { No. }\end{array}$ & Unit & Description & Asses sment \\
\hline $214-2$ & 91 & $\begin{array}{l}\text { Shallow, roughly circular disturbance }(17 \times 20 \times 5 \mathrm{~cm} \text {.) } \\
\text { with irregular outline in profile; margins disturbed; } \\
\text { one lump of charcoal in fill but no artifacts. }\end{array}$ & Noncul tural \\
\hline $214-3$ & 91 & $\begin{array}{l}\text { Circular disturbance }(17 \times 17 \times 23 \mathrm{~cm} \text {. }) \text { containing brown, } \\
\text { red-mottled sand and wash lenses in the lower portion; } \\
\text { margins distinct; no artifacts or charcoal noted in fill. }\end{array}$ & $\begin{array}{l}\text { Cultural, possible } \\
\text { aboriginal posthole } \\
\text { (based on shape, size, } \\
\text { nature of fill) }\end{array}$ \\
\hline $214-4$ & 91 & $\begin{array}{l}\text { Sha1low, irregularly-shaped disturbance }(27 \times 34 \times 9 \mathrm{~cm} .) \\
\text { containing recent plow zone fi11; margins distinct; no } \\
\text { charcoal or artifacts noted. }\end{array}$ & Noncul tura 1 \\
\hline $214-5$ & 91 & $\begin{array}{l}\text { Shallow, vaguely-defined circular disturbance }(15 \times 15 \times 5 \\
\mathrm{cm.} \text { ); much rodent disturbance; no charcoal or artifacts noted. }\end{array}$ & Noncultura 1 \\
\hline $214-6$ & 91 & $\begin{array}{l}\text { Deep, irregularly-shaped disturbance }(36 \times 36 \times 127 \mathrm{~cm} .) \\
\text { containing very loose fi11; margins distinct; no charcoal } \\
\text { or artifacts noted. }\end{array}$ & $\begin{array}{l}\text { Noncultural, root } \\
\text { mold? }\end{array}$ \\
\hline $214-7$ & 92 & $\begin{array}{l}\text { This feature number was assigned to plow mark which was } \\
\text { later removed in troweling. }\end{array}$ & $\begin{array}{l}\text { Noncultura 1, plow } \\
\text { mark }\end{array}$ \\
\hline 214-8 & 92 & $\begin{array}{l}\text { Semicircular (only one-half of feature exposed), basin- } \\
\text { shaped disturbance ( } 37 \times 17 \times 14 \mathrm{~cm} \text {.) containing dark } \\
\text { gray-brown fill; margins distinct; no charcoal or artifacts } \\
\text { noted. }\end{array}$ & $\begin{array}{l}\text { Cultural, possible } \\
\text { aboriginal pit } \\
\text { (based on shape, size, } \\
\text { nature of fill) }\end{array}$ \\
\hline 214-9 & 92 & $\begin{array}{l}\text { Shallow, oval disturbance }(25 \times 18 \times 6 \mathrm{~cm} \text {. }) \text { with diffuse, } \\
\text { vaguely-defined margins; no artifacts or charcoal noted. }\end{array}$ & Noncul tura 1 \\
\hline
\end{tabular}


TABLE 4, Continued.

$\begin{aligned} & \text { Feature } \\ & \text { No. Unit } \\ & \text { Description }\end{aligned}$

214-10 92 This feature number was assigned to a disturbance which disappeared after the second troweling.

215-1 $102 \quad$ Roughly circular, basin-shaped disturbance $(29 \times 25 \times 13$ $\mathrm{cm}$.$) containing greenish-gray fill; margins disturbed and$ somewhat diffuse; no charcoal or artifacts noted.

216-1 103 Circular, basin-shaped disturbance $(24 \times 26 \times 9 \mathrm{~cm}$. $)$ containing greenish-gray fi11; margins distinct; no charcoal or artifacts noted.

Circular, basin-shaped disturbance $(28 \times 28 \times 10 \mathrm{~cm}$. containing greenish-gray fill; margins distinct; no charcoal or artifacts noted.

$216-3$

Circular disturbance $(32 \times ? \times 10 \mathrm{~cm}$.) containing greenish-gray fill; margins distinct; no charcoal or artifacts noted.

$216-4$

$216-5$

106

$216-6$
Roughly circular disturbance $(33 \times 29 \times 13 \mathrm{~cm}$.) containing greenish-gray fill; margins somewhat disturbed by rodents but very distinct; no charcoal or artifacts noted.

Roughly circular disturbance $(27 \times 24 \times 11 \mathrm{~cm}$.) containing greenish-gray fi11; margins distinct; no charcoal or artifacts noted.

Semicircular (feature not fully exposed) disturbance $(33 \times 23 \times 8 \mathrm{~cm}$.) containing greenish-gray fi11; margins distinct; no charcoal or artifacts noted.
Noncultural

Cultura 1, historic tree-planting hole?

Cultural, historic tree-planting hole?

Cultural, historic tree-planting hole?

Cultural, historic tree-planting hole?

Cultural, historic tree-planting hole?

Cultural, historic tree-planting hole?

Cultural, historic tree-planting hole? 
TABLE 4, Continued.

Feature
No. Unit Description Assessment

217-1 $105 \quad$ Circular, basin-shaped disturbance (ca. $28 \times 28 \times 13 \mathrm{~cm}$.)
containing greenish-gray fil1; margins distinct; feature truncated by modern plow zone; no charcoal or artifacts in fill.

217-2 105 This feature number was assigned to a small concentration of three pieces of hematite $(3-7 \mathrm{~cm}$. in diameter); no pit visible; no in situ burning; no charcoal or artifacts associated.

217-3 105 This feature number was assigned to a small concentration of two pieces of hematite and one sherd; no pit visible; no in situ burning; no charcoal associated; feature bisected by rodent burrow.

218-1 104 Apparently circular (this feature originally appeared in unit wa11), basin-shaped disturbance $(25 \times ? \times 10 \mathrm{~cm}$.) containing greenish-gray fil1; margins distinct; no charcoal or artifacts noted.

219-1 108 Apparently circular (this feature appeared in unit wal1), basin-shaped disturbance $(28 \times ? \times 11 \mathrm{~cm}$.) containing greenish-gray fill; margins distinct; no charcoal or artifacts noted.

Cultural, historic tree-planting hole?

Noncultural, probable rodent cache

Noncultura 1, possible rodent cache

Cultura 1, historic tree-planting hole?

Cultura 1, historic tree-planting hole? 
The aboriginal features include one posthole (F214-1 in Unit 91), one hematite concentration (F203-2 in Unit 75), and seven pits (F200-1, 2 and 3 in Unit 71; F197-4 in Unit 66; F210-1 in Unit 85; F2l2-1 in Unit 88; and F214-8 in Unit 92). Given the large number of artifacts found in the excavations and the extent of occupation within the project area, it is somewhat surprising that additional features, especially structures, were not located. However, this probably can be attributed to the facts that the excavation units were very widely spaced and that time limitations prevented expansion of excavations in areas known to contain features (e.g., in the vicinity of F214-1).

It is difficult to draw conclusions about these features when their small number of occurrence is considered. The hematite concentration (F203-2) is similar to others found in previous excavations. (Newell and Krieger 1949: 52; Fields 1978: 6, 12), but its function remains undetermined. F214-1 is designated a posthole on the basis of its shape and size, but in view of a lack of associated postholes, it is impossible to determine its significance. The remaining seven features are designated as pits based on size, shape and similarities to previously described features at the site (Spock 1977; Fields 1978; Creel 1979; Thurmond and Kleinschmidt 1979), but their precise functions also remains a mystery. Six of the seven pits (F212-1 is excluded) and the single posthole all contained fill materials which were relatively distinct from the surrounding matrix in terms of color and compactness; this is a sharp contrast when compared to the extremely subtle variations noted in many of the features encountered during the 1977 Davis Site investigations. This relative distinctness 
suggests that these features may be more recent than the Alto Focus occupation. As will be shown later, the artifacts recovered support this conclusion.

The single cultural feature (F204-2) with an undetermined temporal affiliation is a small concentration of burned clay lumps which lacks in situ burning. Similar concentrations have been found in previous excavations (Fields 1978; Creel 1979); however, all that can be said about them is that they represent highly disturbed areas of limited burning. That F204-2 was found in close proximity to an historic feature (F204-1) and in a unit with a very low artifact density suggests that it may be the result of recent burning.

The 26 historic features include 16 pits interpreted as the remains of an unsuccessful orchard, four features which probably represent structure footings, two postholes (fenceposts?), two pits of undetermined function, one auger hole, and one compacted area possibly associated with agricultural terracing.

The 16 features proposed here as representing an orchard (F201-3; 203-1, 3, 4 and 5; 211-1; 216-1, 2, 3, 4,5 and $6 ; 217-1 ; 218-1 ;$ and 219-1) are circular, basinshaped pits containing a very distinctive greenish-gray fill. They range in diameter from ca. 24 to $33 \mathrm{~cm}$ with nine (56.25\%) having diameters of $26-28 \mathrm{~cm}$. Depths below detection level range from 8 to $19 \mathrm{~cm}$ with twelve (75.00\%) having depths of 10-13 cm. These disturbances were found only in the northwestern portion of Area 1 (four in Unit 75; four in Unit 106; two in Unit 103; and one each in Units 72, 87, 102, 104, 105 and 108). Ten of these were found in contiguous units, Units 75, 103 and 106; they form 
a gridlike arrangement which is oriented roughly with the four cardinal directions and which exhibits an occurrence interval of 3.60-3.80 meters between adjacent features. The identification of these features as historic seems quite secure in view of their arrangement (as seen in Units 75, 103 and 106) and their widespread occurrence over this part of the site. That is, it is very difficult to conceive of nearly identical aboriginal features arranged in a ca. 3.70-meter grid over an area of at least 4000 square meters (the area of the site encompassing units containing these features). Also, it seems more than coincidental that the 3.60-3.80-meter interval converts to 11.8-12.5 feet, or roughly 12 feet.

The proposal that these 16 features represent an unsuccessful orchard is somewhat problematical. This explanation was first proposed after local informants reported that an orchard did exist in the generaly vicinity many years ago (early twentieth century?). However, this explanation requires that the planted trees never took root since none of these features has a root mold extending from the bottom of the pit. The orchard hypothesis assumes, in addition to the idea that the trees did not take root, that (1) shallow pits were dug in which to plant the trees; and (2) the trees were planted with peat moss or some other organic-rich soil around the root bundle. An organic-rich soil around the roots could well explain the peculiar, sterile, greenish-gray fill in these pits. This hypothesis is further supported by the arrangement, spacing and extent of the pits and the lack of historic artifacts in and around the features (since one would not expect historic trash to be deposited in an orchard or to be associated with the planting of trees). 
Four features (F207-1, 2, 3 and 4) in Unit 81 are interpreted as representing foundation footings for a nondomiciliary structure. These pits had diameters of 30-35 $\mathrm{cm}$ and depths below detection level of 11-16 cm. All four pits contained fill rich in woody charcoal showing that the wooden posts in them had been partially burned while still in place. One of these contained a wire nail within the pit fill. These four pits formed a rectangle with sides of 3.65-3.75 meters (ca. 12 feet) in length. These pits seem too large $(30-35 \mathrm{~cm})$ and shallow $(38-43 \mathrm{~cm}$ below present ground surface) to represent fenceposts but could well have served as footings for a structure. The scarcity of historic artifacts from Unit 81 suggests that this probable structure was non-domiciliary. The presence of the wire nail in pit fill places these features within the modern era.

Unit 77 contained two features (F205-1 and 2) which may represent burned fenceposts. Both were somewhat oval with minimum and maximum diameters of 15-18 cm and 19-26 $\mathrm{cm}$ respectively. Both were quite shallow with maximum depths below detection level of $4 \mathrm{~cm}$ and $10 \mathrm{~cm}(25$ and 31 $\mathrm{cm}$ below present ground surface). These features contained very ashy fills with chunks of woody charcoal; it appears that both contained wooden posts which were thoroughly burned while still in place. One yielded three wire nails while the other contained five wire nails and one cut nail. Both seem quite shallow for fence postholes; however, their small horizontal dimensions and the presence of so many nails renders this a possibility. If indeed they do represent fenceposts, the nails suggest that it was a plank rather than a wire fence, and indicate that the features are modern. 
The remaining four historic features are not distinctive and cannot be easily interpreted. F198-6 in Unit 68 is an area of hard, compacted soil adjacent to a modern agricultural terrace. While this compaction may have occurred when the terrace was constructed, it should be noted that other similarly compacted areas were seen in units well-removed from agricultural terraces and are apparently related to tractor-compaction which occurs during plowing. F198-4 in Unit 68 has been designated a modern auger hole based on its size, shape, the presence of recent plow zone fill, and the inverted stratigraphy of the pit fill. F198-5 in Unit 68 and F204-1 in Unit 76 have been interpreted as modern features due to their sizes, shapes and the nature of their fills; however, their causes or functions are undetermined.

\section{CERAMICS}

The ceramic collection from these investigations contains 2,132 vessel sherds, two coil fragments, 14 pipe fragments, 56 pieces of burned clay, and 11 lumps of kaolin. Although a very small percentage (0.52\%) of the sherd collection can be assigned to established ceramic types, ta much larger percentage $(27.44 \%)$ can be placed into descriptive groups which, because they resemble defined types in paste characteristics, vessel form, decorative motif, or decorative technique, are given temporal significance in this analysis.

This collection is divided into nonvessel and vessel ceramics. The categories of vessel ceramics are presented in three gross temporal groups (Pre-Caddoan, Early Caddoan 
and Late Caddoan) and one temporally undiagnostic group. The discussion of the collection, which follows the category descriptions, deals mostly with the temporally-diagnostic specimens; however, all sherds are included in the discussions of sherd densities and in the sherd provenience tables (see Tables 5 through 9).

\section{Nonvessel Ceramics (Table 5)}

Pipe Fragments

All of the pipe fragments recovered are pieces of bowls. Four specimens are portions of the lower bowl/stem juncture area and clearly represent elbow pipes which are common in Late Caddoan contexts. All four are tempered with finely-ground grog; in addition, one specimen exhibits pulverized bone. The ten remaining pipe fragments are from the upper portions of bowls and cannot be readily placed within a temporal framework. Three of these have flattened lips, two have thinned lips and the remainder lack lips. Most of the upper bowl fragments appear to be tempered with fine sand or finely-ground grog. All of the pipe fragments exhibit undecorated exteriors.

\section{Burned Clay}

Fifty-six pieces of burned clay were found. One small lump from Unit 79 has twig impressions and appears to be wattle-impressed daub. The rest may be cultural in that they represent episodes of burning (possibly in a hearth or as daub); however, they cannot be related definitely to the aboriginal occupation of the site. 
TABLE 5

PROVENIENCE OF NON-VESSEL CERAMICS

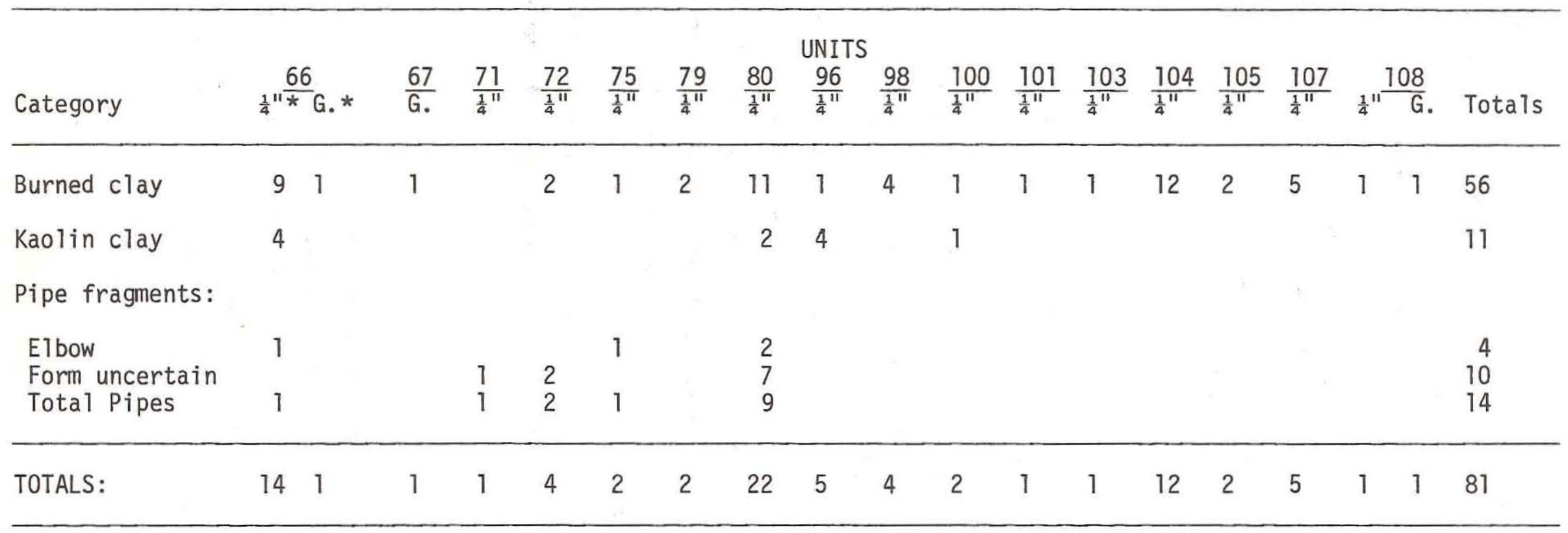

$*_{\frac{1}{4}} "=$ screened material; G. = unscreened general fill. 
Kaolin

The eleven small lumps of white kaolin clay recovered in these excavations were undoubtedly transported to the site; perhaps these items were intended for use as pigment or as a tempering agent in ceramic vessel manufacture.

\section{Vessel Ceramics}

Pre-Caddoan (Table 6)

Eighty-five sandy paste sherds and one sandy paste coil fragment were recovered. These distinctive specimens, which lack any tempering agent other than quartz sand, very probably represent a pre-Caddoan occupation of the site. All of these specimens are undecorated. One rim sherd is large enough to show that it was from a simple bowl. One body sherd has a biconically-drilled hole (ca. $4 \mathrm{~mm}$ in diameter) which may represent an instance of vessel repair.

Early Caddoan (Table 7)

Typed Rim

Davis Incised, Variety Unspecified. The single sherd of this type, from Unit 85 , is decorated with closely-spaced (4 mm), carefully-executed, overhanging, horizontal incised lines. It is apparently from a simple bowl.

Weches Fingernail-Impressed. This type is represented by three sherds. Two show two or more horizontal rows of fingernail impressions separated by incised lines on the rim. Neither of these is large enough to show body treatment. The third has a single row of fingernail impressions above closely-spaced, vertical incising on the body. All appear to be from jars with everted rims. 
TABLE 6

PROVENIENCE OF PRE-CADDOAN (SANDY PASTE) CERAMICS

\begin{tabular}{|c|c|c|c|c|c|c|c|c|c|c|c|c|c|c|c|c|c|c|c|c|}
\hline Category & & $\frac{66}{\star}$ G. * & $\frac{67}{\frac{1}{4} 1^{11}}$ & $\frac{68}{\frac{1}{4} 1^{11}}$ & $\frac{1}{4} 11 \frac{69}{G}$ & $\frac{74}{\frac{1}{4} 11}$ & $\frac{75}{\frac{1}{4} 11}$ & & $\frac{80}{G .}$ & $\frac{87}{\frac{1}{4} 11}$ & $\frac{88}{\frac{1}{4} 11}$ & $\begin{array}{l}\text { UNI } \\
\frac{93}{\frac{1}{4} 11}\end{array}$ & $\begin{array}{l}\frac{94}{\frac{111}{4}} \\
\text { S }\end{array}$ & $\frac{1}{4} 11 \frac{96}{6}$ & & $\frac{97}{G .}$ & $\frac{1}{4} 11 \frac{98}{G}$. & $\frac{101}{\frac{1^{\prime \prime}}{4}}$ & $\frac{108}{\frac{1111}{4}}$ & Totals \\
\hline Rim & & 2 & & & & & & & & & & & & 1 & & & 1 & & & 4 \\
\hline Body & 1 & & 1 & 1 & 101 & 1 & 1 & 5 & 1 & 1 & 4 & 1 & 4 & 29 & 6 & 5 & 6 & 1 & & 81 \\
\hline $\begin{array}{l}\text { Coil } \\
\text { fragment }\end{array}$ & & & & & & & & & & & & & & & & & & & 1 & 1 \\
\hline TOTALS: & 1 & 2 & 1 & 1 & 101 & 1 & 1 & 5 & 1 & 1 & 4 & 1 & 4 & 30 & 6 & 5 & 7 & 1 & 1 & 86 \\
\hline
\end{tabular}

$\star_{\frac{1}{4}} "=$ screened material; G. = unscreened general fill. 
Holly Fine-Engraved. The single sherd of this Alto Focus, Davis Site type has a badly eroded surface which exhibits faint traces of finely-engraved, parallel, diagonal lines on the rim of a carinated bowl.

\section{Untyped Body}

Pinched, Whorl Motif. Two body sherds which fit together exhibit a motif shown by previous investigations to be characteristic of the Early Caddoan occupation of the Davis Site (Newell and Krieger: 121, Fig. 46F; Thurmond and Kleinschmidt 1979: 37). Pinches, paired along an arcuate line, alternately slant to the left and right of the general trend of that line.

\section{TABLE 7}

PROVENIENCE OF EARLY CADDOAN VESSEL CERAMICS

\begin{tabular}{|c|c|c|c|c|c|c|c|}
\hline Category & $\frac{67}{\frac{1}{4} 11 *}$ & $\frac{79}{\frac{111}{4}}$ & $\frac{85}{\frac{1}{4} 11}$ & $\frac{94}{\frac{111}{4}}$ & $\frac{101}{\frac{101}{4}}$ & $\frac{103}{\frac{103}{4}}$ & Totals \\
\hline Davis Incised & & & 1 & & & & 1 \\
\hline $\begin{array}{l}\text { Weches Fingernail- } \\
\text { Impressed }\end{array}$ & & 1 & & & 1 & 1 & 3 \\
\hline Holly Fine-Engraved & & & & 1 & & & 1 \\
\hline Pinched, Whorl Motif & 2 & & & & & & 2 \\
\hline TOTALS: & 2 & 1 & 1 & 1 & 1 & 1 & 7 \\
\hline
\end{tabular}


Late Caddoan (Table 8)

Typed

Poyner Engraved. Six sherds have been assigned to this Late Caddoan type. One body sherd is from a bottle with an elongated body. The remainder are from bowls. All exhibit portions of the characteristic Poyner Engraved motif which consists of an oval panel flanked by engraved lines arched back-to-back (Suhm and Jelks 1962: 123, 125, P1.62, 63). The bottle sherd contains red pigment in the engraved lines.

\section{Untyped Rim}

Engraved, Slanted Scroll Motif. A single sherd from a carinated bowl shows a portion of this motif in which hatched triangles flank a continuous negative scroll. The slanted scroll motif is commonly found on the Late Caddoan types Ripley Engraved and Taylor Engraved (Suhm and Jelks 1962: 127, 129, 149, 151, Pl. 64, 65, 75, 76).

Wet Paste, Parallel Diagonal Lines. This category includes sherds from the rims of everted-rim jars which exhibit motifs traditionally considered characteristic of the Late Caddoan type Maydelle Incised (Suhm and Jelks 1962: 103, P1. 52). Decorative techniques include incising, instrument punctation and fingernail impression. The incised motifs represented are broad cross-hatching (3); unidirectional, diagonal lines (11); and alternating equilateral triangular zones filled with hatching (11). One sherd shows the latter motif executed by the placing of fingernail impressions end-to-end. Eight sherds exhibit equilateral triangular zones filled with hatching which 
TABLE 8

PROVENIENCE OF LATE CADDOAN VESSEL CERAMICS

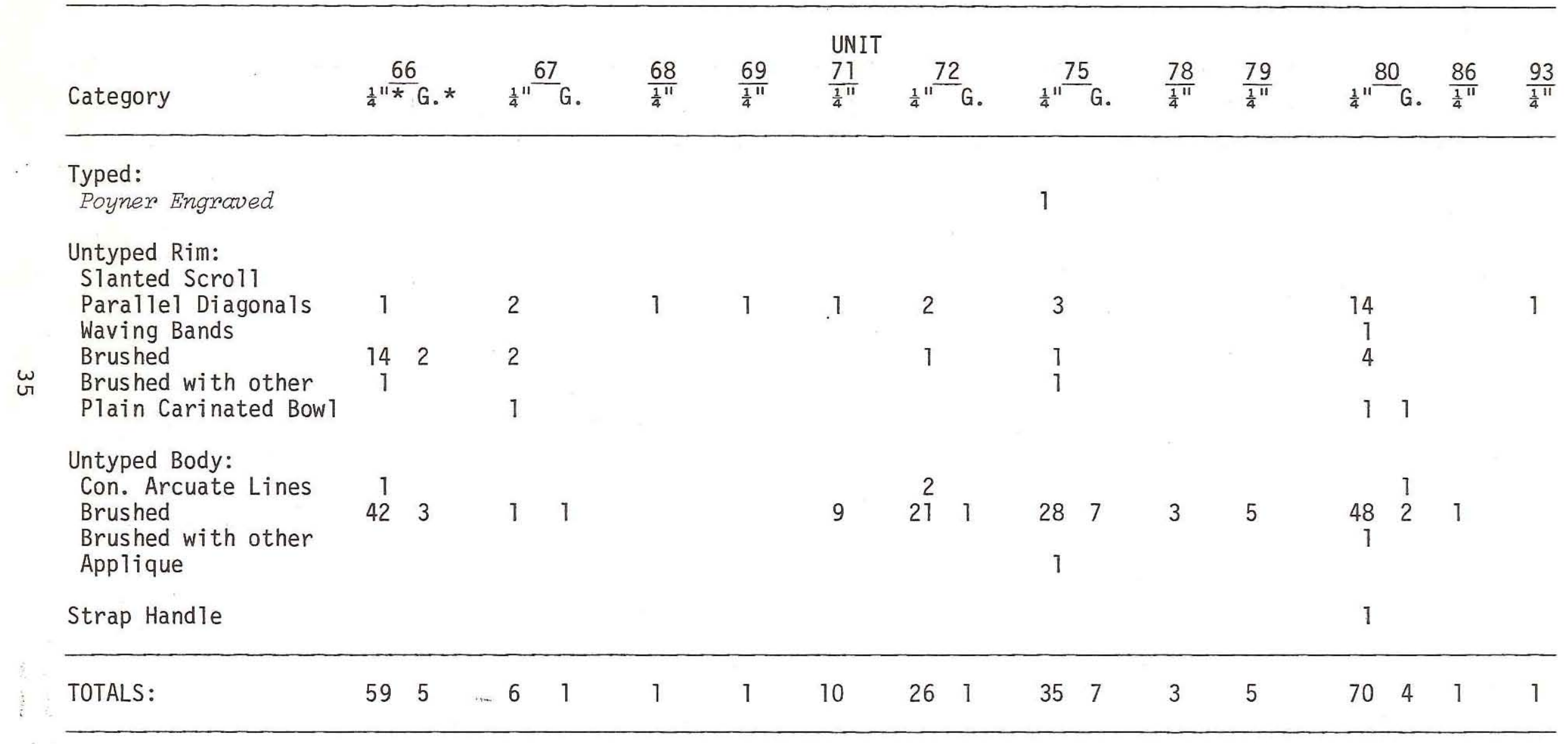

$*_{\frac{1}{4}} \|=$ screened material; G. = unscreened general fill. 
TABLE 8, Continued.

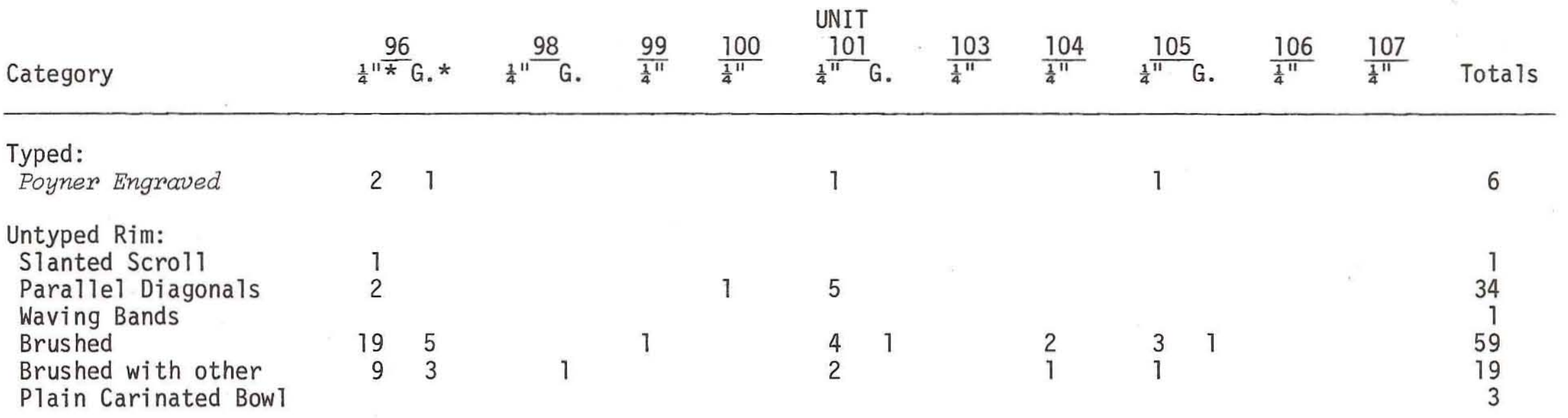

Untyped Body:

Con. Arcuate Lines

Brushed

Brushed with other

Applique

$\begin{array}{rrr}102 & 17 & 2 \\ 6 & 2 & \\ & 2\end{array}$

$1 \quad 20$

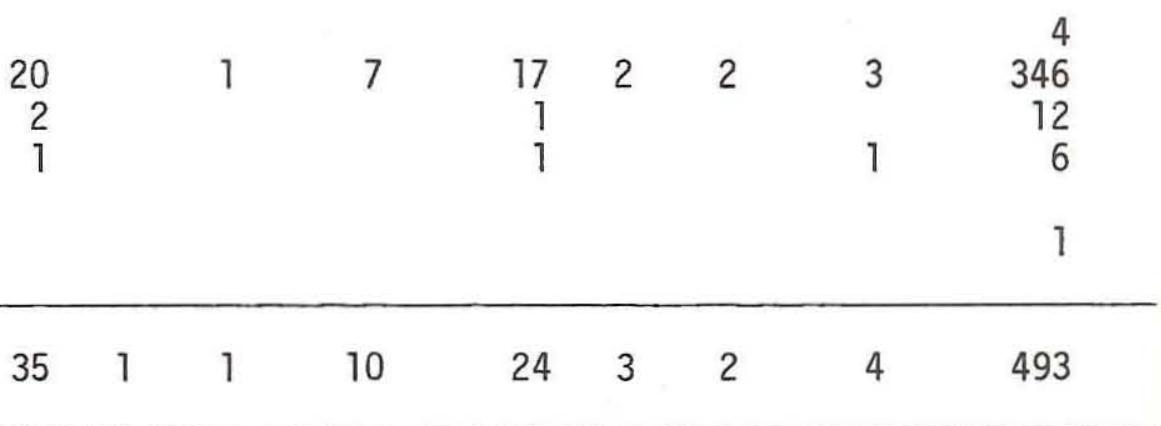

Strap Handle

TOTALS:

14130

211


alternates with zones filled with instrument punctations.

Wet Paste, Waving Horizontal Bands. A single sherd

from a jar with an everted rim shows two horizontal waving bands filled with small instrument punctations and flanked by incised lines around the rim. This motif and vessel form are characteristic of the type Pineland Punctated-Incised (Jelks 1965: 119-122).

Brushed. Fifty-nine sherds from jars with everted rims show this treatment. This surface treatment is generally characteristic of Late Caddoan ceramic assemblages (Suhm and Jelks 1962: 21, P1. 11).

Brushed with Other Wet Paste Treatment. Three other wet paste decorative techniques occur in combination with brushing: incising (2), fingernail impression (16), and applique (1). These sherds also appear to be from evertedrim jars. On both of the incised sherds, the incised lines are broad, deep and horizontal. Eleven of the sherds with fingernail impressions exhibit a single horizontal row of impressions immediately below the lip. The other five sherds have a single horizontal row of impressions near the center of the rim. A single sherd shows vertical brushing combined with a vertical applique strip containing fingernail impressions.

Plain Carinated Bowl. Three plain rim sherds are from carinated bowls with inverted, convex-walled rims having an outward-rolled lip. This vessel form is characteristically Late Caddoan.

Untyped Body

Engraved Bottle, Concentric Arcuate Lines. Four body sherds from bottles show two or more engraved, concentric 
arcuate lines. This decorative treatment on bottles is common to several Late Caddoan ceramic types such as Tayzor Engraved (Suhm and Jelks 1962: 149, 151, P1. 75, 76).

Brushed. Three hundred and forty-six body sherds which exhibit brushing as the sole decorative technique were recovered in the excavations. As noted, this technique is distinctively Late Caddoan.

Brushed with Other Wet Paste Treatment. Four wet paste decorative techniques occur in combination with brushing on body sherds: incising, instrument punctation, fingernail impression and pinching. A single sherd has diagonal brushing with closely-spaced, parallel incised lines superimposed over the brushing. On two sherds single horizontal rows of instrument punctations are bound above and below by horizontal brushing. Six sherds show a similar motif using fingernail impressions instead of instrument punctations. Finally, three sherds exhibit vertical brushing flanking vertical applique strips. The sherds in this group are from the bodies of bowls and jars.

Applique. Six sherds show no decoration other than applique strips. On one sherd the strip contains diagonal incised slashes while three sherds have strips with instrument punctations, and two have unadorned strips.

Strap Handle

A fragment of a strap handle from the rim of a Late Caddoan jar was recovered from Unit 80. The shaft of the handle is plano-convex in cross-section, and its juncture with the wall of the vessel is subrectangular. Its exterior surface is undecorated and unsmoothed. 
Temporally Nondiagnostic Caddoan (Table 9)

Decorated Rims

Engraved. Nine rim sherds show engraved lines, but the motifs represented cannot be determined. One of these has a scalloped lip while another is peaked. These sherds are probably from carinated bowls. Scalloped and peaked rims are more common on Late Caddoan vessels, but they also occur on some Early Caddoan forms as well.

Incised. Nine rim sherds have incised lines but indeterminate motifs. These sherds represent bowls and jars.

Engraved/Incised, Uncertain. Two rim sherds are decorated with lines which could be either incised or engraved. Motifs represented cannot be determined.

Instrument Punctated. This category includes five rim sherds which are decorated solely with instrument punctations. Three show punctations distributed randomly on the rim while the fourth has two horizontal rows of punctations encircling the rim. A fifth sherd has punctations bordered by a curved, vertical, incised line. These sherds are from bowls and jars.

Fingernail Impressed. Nine rim sherds representing seven small jars with everted rims are decorated only with fingernail impressions. The impressions are randomly distributed on seven of the sherds and form single horizontal lines immediately beneath the lip of two specimens.

pinched. This category consists of ten rim sherds from a single small everted-rim jar. The pinches are vertically oriented.

Neck-Banded. Three sherds have incompletely obliterated coil marks. One has a peaked rim. These sherds are from jars with everted rims. Since these sherds are 
TABLE 9

PROVENIENCE OF TEMPORALLY NONDIAGNOSTIC CADDOAN VESSEL CERAMICS

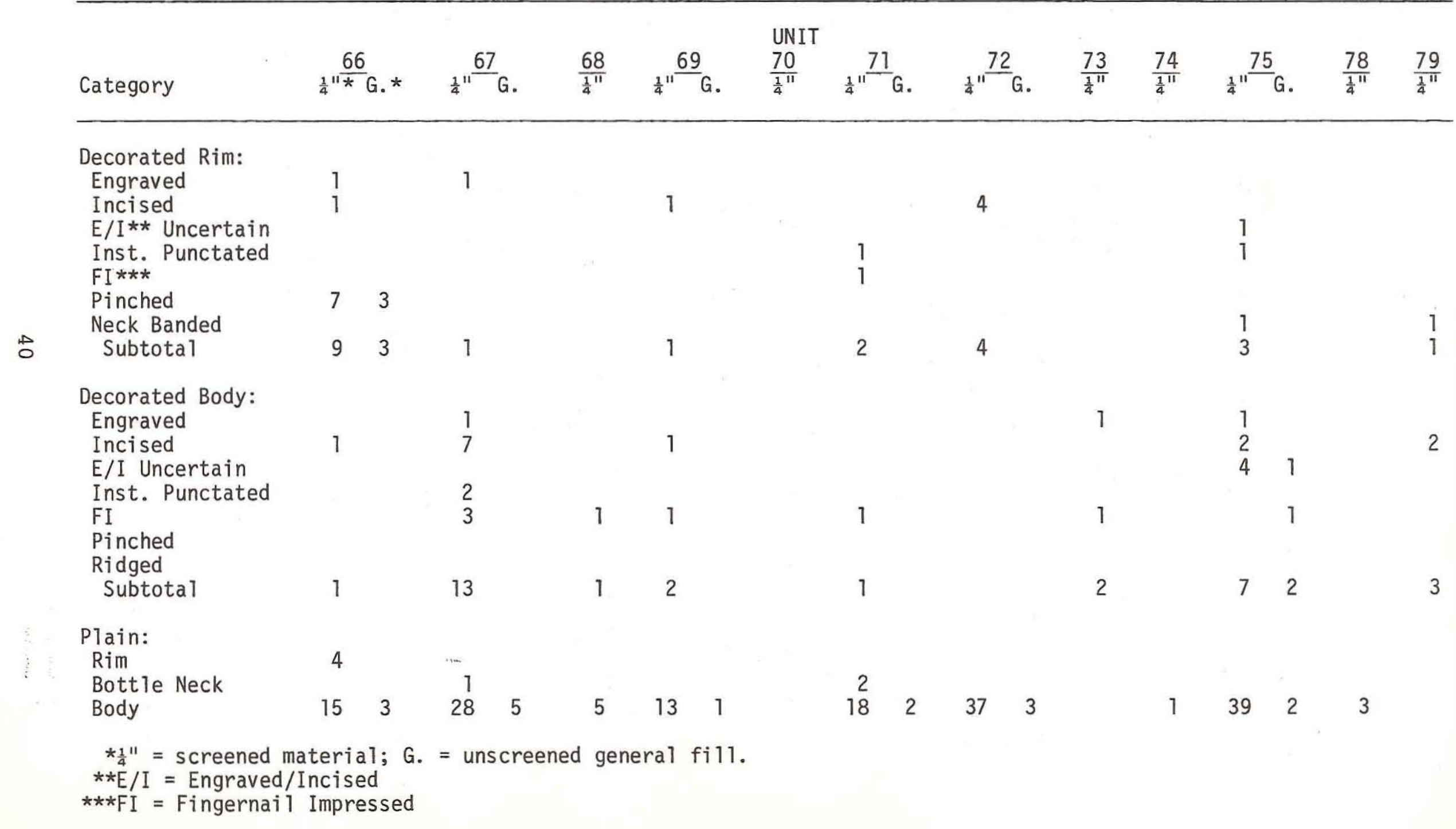


TABLE 9, Continued.

\begin{tabular}{|c|c|c|c|c|c|c|c|c|c|c|c|c|c|c|c|c|c|c|}
\hline Category & & \multicolumn{2}{|c|}{67} & $\frac{68}{\frac{1111}{4}}$ & \multicolumn{2}{|c|}{69} & $\begin{array}{l}\text { UNIT } \\
\frac{70}{\frac{1}{4} 11}\end{array}$ & \multicolumn{2}{|c|}{71} & \multicolumn{2}{|c|}{72} & $\frac{73}{\frac{111}{4}}$ & $\frac{74}{\frac{11}{4}}$ & \multicolumn{2}{|c|}{$\underline{75}$} & $\frac{78}{\frac{12}{4} 11}$ & $\frac{79}{\frac{13}{4}}$ \\
\hline $\begin{array}{l}\text { Base } \\
\text { Subtotal }\end{array}$ & 19 & 3 & 29 & 5 & 5 & 13 & 1 & & 20 & 2 & 37 & $\begin{array}{l}1 \\
4\end{array}$ & & 1 & 39 & 2 & 3 & \\
\hline Coil Fragment & & & & & & & & & & & & & & & & & & \\
\hline Unclassifiable & 31 & 1. & 29 & 2 & 1 & 6 & & 1 & 43 & & 88 & 9 & 3 & & 53 & 3 & & 9 \\
\hline TOTALS: & 60 & 7 & 72 & 7 & 7 & 22 & 1 & 1 & 66 & 2 & 129 & 13 & 5 & 1 & 102 & 7 & 3 & 13 \\
\hline
\end{tabular}

$\stackrel{\mapsto}{\mapsto}$

\begin{tabular}{|c|c|c|c|c|c|c|c|c|c|c|c|c|c|}
\hline & & & & & & JNIT & & & & & & & \\
\hline Category & $\frac{1}{4}{ }^{\prime \prime} \frac{80}{G .}$ & $\frac{85}{\frac{1}{4}^{11}}$ & $\frac{86}{\frac{1}{4}{ }^{11}}$ & $\frac{87}{\frac{1}{4} 11}$ & $\frac{88}{\frac{1}{4} 11}$ & $\frac{89}{\frac{1}{4} 11}$ & $\frac{90}{\frac{1}{4}{ }^{11}}$ & $\frac{1}{4} \stackrel{91}{\mathrm{G}}$. & $\frac{92}{\frac{1}{4}^{11}}$ & $\frac{93}{\frac{1}{4} !}$ & $\frac{94}{\frac{1}{4}}$ & $\frac{1}{4}{ }^{11} \stackrel{96}{G .}$ & $\frac{97}{G .}$ \\
\hline
\end{tabular}

\footnotetext{
Decorated Rim:

Engraved

Incised

E/I Uncertain

Inst. Punctated

FI

Pinched

Neck Banded

Subtota 1
}

3

2

1

\section{1}

6

$7 \quad 1$ 
TABLE 9, Continued.

\begin{tabular}{|c|c|c|c|c|c|c|c|c|c|c|c|c|c|c|c|c|}
\hline Category & $\frac{1}{4}{ }^{11}$ & $\underline{0}_{G}$. & $\frac{85}{\frac{1}{4}^{11}}$ & $\frac{86}{\frac{1}{4}}$ & $\frac{87}{\frac{1}{4} 1^{11}}$ & $\begin{array}{l}\text { UNIT } \\
\frac{88}{\frac{1}{4} 11}\end{array}$ & $\frac{89}{\frac{1}{4} 1^{11}}$ & $\frac{90}{\frac{11^{11}}{11}}$ & $\frac{1}{4} 11^{9}$ & 1 & $\frac{92}{\frac{1}{4} 1^{11}}$ & $\frac{93}{\frac{1}{4} 1^{11}}$ & $\frac{94}{\frac{11^{11}}{11}}$ & & $\frac{36}{G .}$ & $\frac{97}{\mathrm{G} .}$ \\
\hline $\begin{array}{l}\text { Decorated Body: } \\
\text { Engraved } \\
\text { Incised } \\
\text { E/I Uncertain } \\
\text { Inst. Punctated } \\
\text { FI } \\
\text { Pinched } \\
\text { Ridged } \\
\text { Subtotal }\end{array}$ & $\begin{array}{r}11 \\
9 \\
6 \\
6 \\
2\end{array}$ & 1 & & 3 & 3 & & & & 1 & & & 2 & 2 & $\begin{array}{l}9 \\
2 \\
5 \\
4\end{array}$ & $\begin{array}{l}2 \\
1 \\
1 \\
1\end{array}$ & \\
\hline $\begin{array}{l}\text { Plain: } \\
\text { Rim } \\
\text { Bottle Neck } \\
\text { Body } \\
\text { Base } \\
\text { Subtotal }\end{array}$ & $\begin{array}{r}3 \\
1 \\
106 \\
7 \\
117\end{array}$ & 17 & 3 & 1 & 1 & 3 & 1 & 1 & 2 & 1 & & 1 & 1 & $\begin{array}{r}50 \\
5 \\
61\end{array}$ & $\begin{array}{r}2 \\
8 \\
1 \\
11\end{array}$ & 1 \\
\hline Coil Fragment & 1 & & & & & & & & & & & & & & & \\
\hline Unclassifiable & 150 & 11 & & 8 & 12 & 9 & 1 & & 6 & & 2 & 3 & 8 & 152 & 11 & \\
\hline TOTALS: & 307 & 29 & 4 & 12 & 17 & 12 & 2 & 1 & 10 & 1 & 2 & 6 & 11 & 240 & 28 & 1 \\
\hline
\end{tabular}


TABLE 9, Continued.

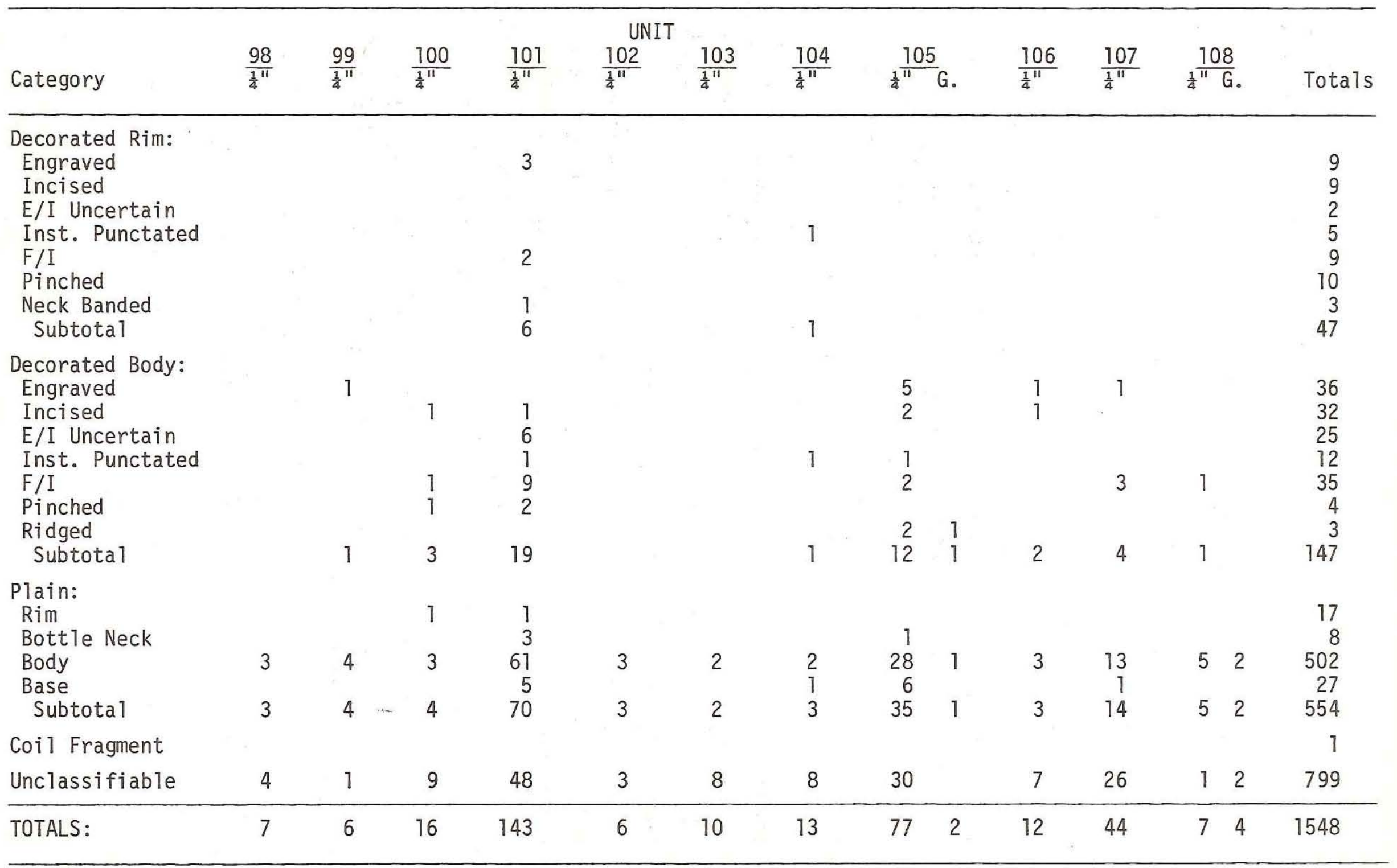


too small to indicate body treatment, they remain temporally nondiagnostic.

\section{Decorated Body}

Engraved. Thirty-six body sherds show engraving, but the motifs represented cannot be determined. One sherd has zoned cross-hatching; six have zoned hatching; five have multiple parallel lines; and twenty-four have single engraved lines. Twenty-five are from bowls or jars while eleven are from bottles. Two are red slipped.

Incised. Thirty-two body sherds have incised lines forming indistinguishable motifs. Three have zoned hatching; one has parallel vertical lines; three are cross-hatched; and twenty-five have short segments of one or more incised lines. All are from bowls or jars.

Engraved/Incised, Uncertain. Twenty-five sherds have one or more engraved or incised lines. Motifs represented cannot be determined. All are from bowls or jars.

Instrument punctated. Twelve sherds from the bodies of bowls or jars have randomly distributed instrument punctations.

Fingernail Impressed. Thirty-five sherds, also from the bodies of bowls or jars, have randomly distributed fingernail impressions.

Pinched. Four sherds from the bodies of bowls or jars have fingernail pinches. Two have randomly distributed pinches while the remaining two show linear arrangements.

Ridged. Three body sherds have vertical ridging. All are from bowls or jars. 
Plain

Rims. There are 17 sherds in this category. Fourteen are from everted-rim jars; one is from a simple bowl; and two are from carinated bowls.

Bottle Necks. Eight sherds representing slightly inverting bottle necks were recovered.

Bodies. Five hundred and two plain body sherds were recovered. These include sherds representing carinated bowls, jars, bottles and vessels of indeterminate shape.

Bases. Twenty-seven sherds have been identified as representing the bases of Caddoan vessels.

\section{Coil Fragment}

A single cylindrical coil fragment of typical Caddoan paste was recovered from Unit 80.

\section{Unclassified Caddoan Sherds}

Included in this category are 799 sherds which exhibit characteristically-Caddoan paste attributes but which are too small or surface damaged to classify further. Sherds were considered too small to classify if less than one square centimeter of the exterior surface remained, unless decoration was clearly visible. Any sherd with an exterior surface too severely damaged to permit an accurate determination of surface treatment was also included in this category.

\section{Discussion of Ceramics}

While an in-depth analysis of the ceramic collection is beyond the scope of this report, a brief examination of the data provided here reveals significant time-related trends 
at the George C. Davis Site. Specifically, a very small percentage $(0.33 \%)$ of the sherd collection can be identified as having resulted from an Alto Focus occupation while $23.12 \%$ of the sherd collection (84.27\% of the temporallydiagnostic vessel sherds) can be attributed to a late Caddoan occupation(s) and $3.99 \%$ (13.68\% of the diagnostic specimens) can be assigned to a pre-Caddoan component. Additionally, all of the pipe fragments whose forms are identifiable represent the remnants of elbow pipes which are common in Late Caddoan contexts.

This suggests there is little evidence to support a hypothesis that the Davis Site village extended onto the project area during the Alto Focus occupation of the site. This information, when compared with the findings of Creel's 1978 investigations, suggests that the tributary creek which bisects the recent Texas Forest Service purchase served as the northwestern limit of the extensive Alto Focus village area.

While pre-Caddoan and Late Caddoan ceramics were found, these do not necessarily provide absolute chronological controls for the different occupations. That sandy paste pottery is pre-Caddoan, however, is strongly suggested by research elsewhere in East Texas (see Shafer 1975: 250251; Fields 1979: 13). The interpretation of a Late Caddoan occupation is based primarily upon the occurrence of a few Poyner Engraved sherds and upon the numerous brushed sherds recovered; this period of site use probably dates to late prehistoric times but probably does not extend significantly (if at all) into protohistoric times.

The Caddoan ceramics generally follow the same distributional trend as the other aboriginal artifacts (see Table 19 and Fig. 3); that is, they are especially 


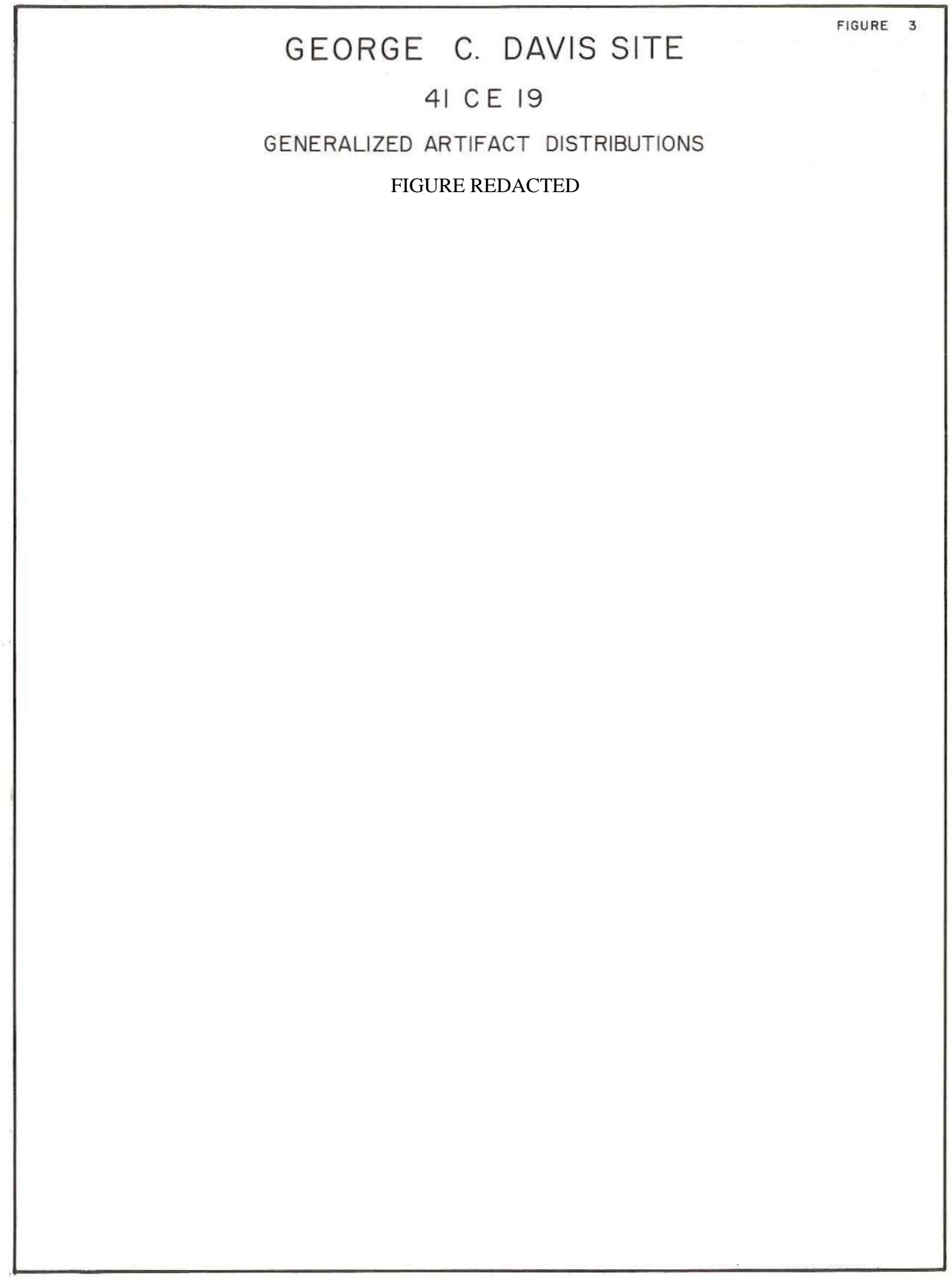


dense in Area 2 and in the northwestern portion of Area 1 , but they decrease in density to the east. In other words, they are concentrated in units close to the terrace edge overlooking Bowles Creek. The sandy paste sherds also have high frequencies in some units in Area 2 but lack high densities in the northwestern part of Area 1. In contrast to the Caddoan styles, the sandy paste ceramics seem to be comparatively more frequent in the western portion of Area 3.

\section{LITHICS}

The lithic materials recovered during these investigations are divided into four groups; three groups are based on the general technique of reduction while the last group consists of unreduced pebbles. These groups are: chipped stone; abraded, pecked and battered stone; polished stone; and unmodified pebbles. The first two groups are further separated into tools, preforms and debitage. The body of this section consists of descriptions of the collection; this is followed by a brief analysis. Tables 10 through 15 provide provenience data for all lithic categories.

\section{Chipped Stone}

Tools

\section{Dart Points (Table 10)}

Expanding-Stem. Seven expanding-stem dart points were recovered. The first specimen is of tan chert; it has a short, triangular blade with straight to slightly convex edges, prominent shoulders and a straight base. 
TABLE 10

PROVENIENCE OF CHIPPED STONE PREFORMS AND TOOLS

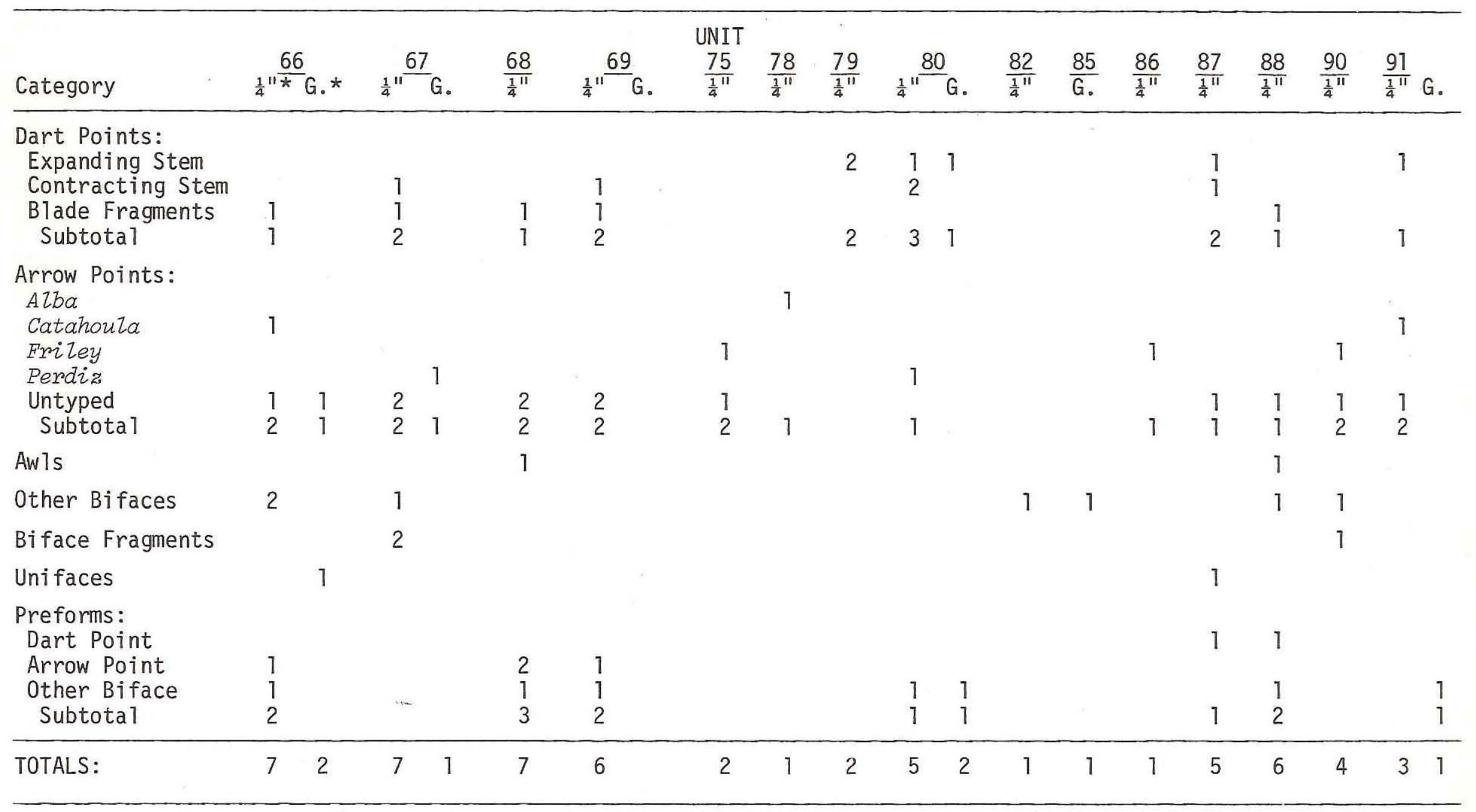

$*_{\frac{1}{4}} "=$ screened material; $G_{0}=$ unscreened general fill. 
TABLE 10, Continued.

\begin{tabular}{|c|c|c|c|c|c|c|c|c|c|c|c|c|c|c|c|c|c|}
\hline Category & $\frac{1}{4} 1^{1}$ & & $\frac{93}{\frac{1}{4} 1^{11}}$ & $\frac{94}{\frac{111}{4}}$ & $\frac{95}{G .}$ & UNI & $\begin{array}{l}T \\
{ }^{6} \\
G .\end{array}$ & $\frac{97}{\frac{14^{\prime \prime}}{11}}$ & $\frac{98}{\frac{1}{4} 11}$ & $\frac{100}{\frac{111}{4}}$ & $\frac{101}{\frac{101}{4}}$ & $\frac{103}{\frac{1111}{4}}$ & $\frac{104}{\frac{1111}{4}}$ & $\frac{105}{\frac{10}{4}{ }^{11}}$ & $\frac{107}{\left.\frac{1}{4}\right)^{11}}$ & $\frac{108}{\frac{1}{4} 11}$ & Totals \\
\hline $\begin{array}{l}\text { Dart Points: } \\
\text { Expanding Stem } \\
\text { Contracting Stem } \\
\text { Blade Fragments } \\
\text { Subtotal }\end{array}$ & 1 & & & & 1 & $\begin{array}{l}1 \\
1\end{array}$ & $\begin{array}{l}1 \\
1\end{array}$ & $\begin{array}{l}1 \\
1\end{array}$ & 1 & $\begin{array}{l}1 \\
1\end{array}$ & & & & & & & $\begin{array}{r}7 \\
9 \\
7 \\
23\end{array}$ \\
\hline $\begin{array}{l}\text { Arrow Points: } \\
\text { Alba } \\
\text { Catahoula } \\
\text { Friley } \\
\text { Perdiz } \\
\text { Untyped } \\
\text { Subtotal }\end{array}$ & & & $\begin{array}{l}1 \\
1\end{array}$ & $\begin{array}{l}2 \\
2\end{array}$ & & $\begin{array}{l}1 \\
3 \\
4\end{array}$ & & & $\begin{array}{l}1 \\
1\end{array}$ & $\begin{array}{l}1 \\
1 \\
2\end{array}$ & & $\begin{array}{l}2 \\
2\end{array}$ & 1 & & & & $\begin{array}{r}1 \\
2 \\
4 \\
4 \\
23 \\
34\end{array}$ \\
\hline Aw1s & & & & & & 1 & & 1 & & & & & & & & & 4 \\
\hline Other Bifaces & & & & & & 1 & & & & & & & & 1 & & 1 & 10 \\
\hline Biface Fragments & & & & 1 & & 2 & & & & & 1 & & & & & & 7 \\
\hline Unifaces & & & & & & & & & & & & & & & & & 2 \\
\hline $\begin{array}{l}\text { Preforms: } \\
\text { Dart Point } \\
\text { Arrow Point } \\
\text { Other Biface } \\
\text { Subtotal }\end{array}$ & & 1 & & & & $\begin{array}{l}2 \\
1 \\
3\end{array}$ & 2 & $\begin{array}{l}1 \\
2\end{array}$ & & & & & & & $\begin{array}{l}1 \\
1\end{array}$ & & $\begin{array}{r}8 \\
5 \\
9 \\
22\end{array}$ \\
\hline TOTALS: & 1 & 1 & 1 & 3 & 1 & 12 & 3 & 4 & 2 & 3 & 1 & 2 & 1 & 1 & 1 & 1 & 102 \\
\hline
\end{tabular}


This specimen, from Unit 80 , can be assigned to the EZZis type (Suhm and Jelks 1962: 187, P1.94).

$\begin{array}{lllllll}\underline{T} & \underline{\mathrm{L}} & \frac{\mathrm{MBW}}{21} & \frac{\mathrm{BW}}{16} & \frac{\mathrm{HL}}{10} & \frac{\mathrm{NW}}{12} & \frac{\mathrm{BD}}{0 *}\end{array}$

The second specimen, from Unit 79 , is of silicified wood. It has a long, triangular blade with straight edges, weak shoulders and a very slightly-expanding stem with a convex base.

$\begin{array}{lllllll}\underline{T} & \underline{\mathrm{L}} & \frac{\mathrm{MBW}}{52} & \frac{\mathrm{BW}}{19} & \frac{\mathrm{HL}}{14} & \frac{\mathrm{NW}}{14} & \frac{\mathrm{BD}}{-2}\end{array}$

The third specimen, from Unit 91 , is also of silicified wood. It has an assymetrical blade with one convex and one straight lateral edge, prominent shoulders and a sharply convex base. This untypeable specimen retains cortex patches on both faces.

$\begin{array}{lllllll}\underline{\mathrm{T}} & \underline{\mathrm{L}} & \frac{\mathrm{MBW}}{2} & \frac{\mathrm{BW}}{15} & \frac{\mathrm{HL}}{13} & \frac{\mathrm{NW}}{15} & \frac{\text { BD }}{-5}\end{array}$

The fourth specimen, also of silicified wood, is from Unit 98. It has a roughly triangular blade with a somewhat bulbous distal end and very slightly convex lateral edges, weak shoulders and a mildly convex base.

$\begin{array}{lllllll}\underline{\mathrm{T}} & \underline{\mathrm{L}} & \frac{\mathrm{MBW}}{24} & \frac{\mathrm{BW}}{19} & \frac{\mathrm{HL}}{15} & \frac{\mathrm{NW}}{17} & \frac{\mathrm{BD}}{-1}\end{array}$

The fifth specimen is from Unit 80 and is fashioned from silicified wood. It has a roughly triangular blade with one straight and one convex lateral edge, weak shoulders and

*All measurements are in millimeters. T = thickness; $\mathrm{L}=$ total length; $\mathrm{MBW}=$ maximum blade width; $\mathrm{BW}=$ base width (at proximal end of stem); HL = haft length; $N W=$ neck width (stem width just below shoulders); $\mathrm{BD}=$ base depth $(+=$ concave, $-=$ convex, $0=$ straight). 
a very gently expanding stem with a straight base. It retains cortex on both faces.

$\begin{array}{lllllll}\underline{T} & \underline{\mathrm{L}} & \frac{\text { MBW }}{7} & \frac{\text { BW }}{12} & \frac{\text { HL }}{12} & \frac{\text { NW }}{14} & \frac{\text { BD }}{0}\end{array}$

The sixth specimen is of silicified wood and is from Unit 87. It has an assymetrical blade with one straight edge and one strongly convex edge, very weak shoulders and a slightly expanding stem with a convex base. It retains cortex on the base.

\begin{tabular}{|c|c|c|c|c|c|}
\hline & $\underline{\mathrm{L}}$ & MBW & BW & $\underline{\mathrm{HL}}$ & NW \\
\hline 5 & 25 & 17 & 15 & 9 & 14 \\
\hline
\end{tabular}

The seventh specimen, also of silicified wood, is from Unit 79. It lacks one shoulder, a portion of one lateral edge, and a portion of the stem. It appears to have had a triangular blade with straight edges, prominent shoulders and a straight base. It retains cortex on one face and on the base.

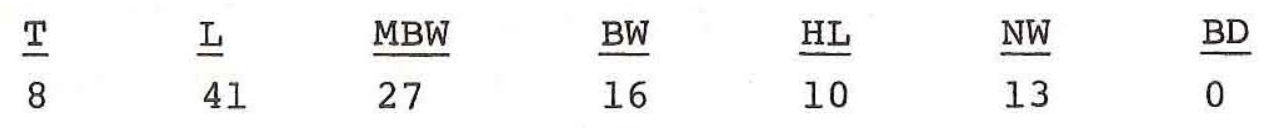

Contracting-Stem. There are nine specimens in this group. Five are base fragments and retain no portion of the blade. Three of these are of chert, one is of silicified wood, and one is of fine-grained quartzite. The other four bifaces in this group are complete, or nearly so, and are described individually.

The first, from Unit 80 , is of light gray chert. It has a large, subtriangular blade with straight to convex lateral edges and a long, gently contracting stem with a convex base. This specimen has a reworked, rounded distal end and can be typed as Bulverde (Suhm and Jelks 1962: 
169, P1. 35).

$$
\begin{array}{lllllll}
\frac{\mathrm{T}}{8} & \frac{\mathrm{L}}{70} & \frac{\mathrm{MBW}}{34} & \frac{\mathrm{BW}}{18} & \frac{\mathrm{HL}}{24} & \frac{\mathrm{NW}}{21} & \frac{\mathrm{BD}}{-2}
\end{array}
$$

The second specimen, from Unit 96 , is of coarsegrained quartzite. It has a triangular blade with one straight edge and one convex edge, weak shoulders and a long, broad, slightly contracting stem with a convex base. This specimen can be typed as Dawson (Duffield 1963: 1718, Fig. 7; Prewitt 1974: 58-62).

$$
\begin{array}{lllllll}
\frac{T}{6} & \frac{\mathrm{L}}{39} & \frac{\mathrm{MBW}}{16} & \frac{\mathrm{BW}}{8} & \frac{\mathrm{HL}}{15} & \frac{\mathrm{NW}}{13} & \frac{\mathrm{BD}}{-1}
\end{array}
$$

The third specimen, from Unit 80 , is also of coarsegrained quartzite. It has a small triangular blade with straight edges, moderate shoulders, and a broad, slightly contracting stem with a convex base. This specimen closely

\begin{tabular}{|c|c|c|c|c|}
\hline$\underline{\mathrm{L}}$ & MBW & $\underline{\mathrm{BW}}$ & $\underline{\mathrm{HL}}$ & NW \\
\hline 24 & 15 & 8 & 11 & 11 \\
\hline
\end{tabular}
resembles the type EZam (Suhm and Jelks 1962: 185, P1. 93).

The fourth specimen, from Unit 87 , is of a very poorly-silicified yellow chert. One shoulder and most of one lateral edge are missing. It has a triangular blade with convex edges, strong shoulders, and a short, broad, slightly contracting stem with a concave base.

$$
\begin{array}{lllllll}
\frac{\mathrm{T}}{8} & \underline{\mathrm{L}} & \frac{\mathrm{MBW}}{40} & \frac{\mathrm{BW}}{30} & \frac{\mathrm{HL}}{13} & \frac{\mathrm{NW}}{9} & \frac{\mathrm{BD}}{16}
\end{array}
$$

Blade Fragments. Included here are seven dart point blade fragments. The stem forms are indeterminate. Five specimens are of silicified wood, one is of chert, and one is of fine-grained quartzite. 


\section{Arrow Points (Table 10)}

Alba. The single specimen of this type, from Unit 78, is of tan chert. A portion of one shoulder and the basal portion of the stem are missing. It has a triangular blade with straight lateral edges (one is serrated), welldefined shoulders, and a parallel-sided stem.

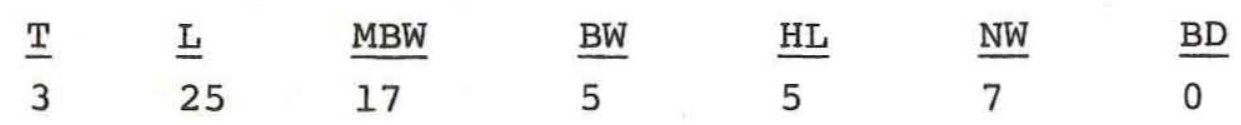

Catahoula. There are two specimens in this group. The first, from Unit 66 , is of fine-grained quartzite. It has a small triangular blade, large outflaring barbs, and a short, slightly expanding stem with a straight base.

$\begin{array}{lllllll}\underline{T} & \underline{\mathrm{L}} & \underline{\mathrm{MBW}} & \frac{\mathrm{BW}}{3} & \frac{\mathrm{HL}}{3} & \frac{\mathrm{NW}}{6} & \frac{\mathrm{BD}}{0}\end{array}$

The second specimen, from Unit 91, is of silicified wood. Most of the blade is missing, and thus blade morphology is unknown although the lower blade edges are serrated. Barbs on this specimen are large and outflaring, the stem is slightly expanding and the base is straight.

$\begin{array}{lllllll}\underline{T} & \underline{L} & \frac{\text { MBW }}{23} & \frac{\text { BW }}{7} & \frac{\text { HL }}{4} & \frac{\text { NW }}{7} & \frac{\text { BD }}{0}\end{array}$

Friley. Four specimens can be placed in this category. The first, from Unit 104, is of silicified wood. It has a roughly triangular blade with one straight lateral edge and one convex edge, prominent upturned barbs and a contracting stem with a convex base.

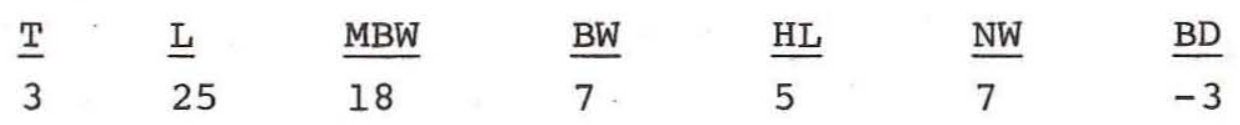

The second specimen, from Unit 90 , is also of silicified wood. The distal half of the blade and a portion 
of one barb are missing. It has a triangular blade with straight lateral edges, prominent upturned barbs and a contracting stem with a convex base.

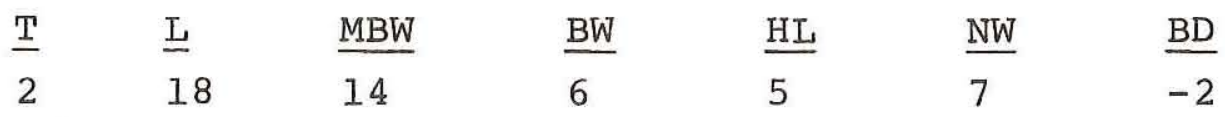

The third specimen, from Unit 75, is of fine-grained quartzite. It has a triangular blade with straight lateral edges, small upturned barbs and a slightly contracting stem with a straight base.

$\begin{array}{lllllll}\frac{\mathrm{T}}{2} & \underline{\mathrm{L}} & \frac{\mathrm{MBW}}{17} & \mathrm{BW} & \frac{\mathrm{HL}}{4} & \frac{\mathrm{NW}}{6} & \frac{\mathrm{BD}}{6}\end{array}$

The fourth specimen, from Unit 86 , is also of finegrained quartzite. One barb is missing. It has a small, triangular blade with straight, serrated lateral edges, a prominent outflaring barb and a rectangular stem with a concave base.

\begin{tabular}{|c|c|c|c|c|c|}
\hline I & MBW & BW & $\mathrm{HL}$ & NW & $\underline{B D}$ \\
\hline 14 & 14 & 6 & 5 & 6 & \\
\hline
\end{tabular}

Perdiz. Four projectile points can be placed in this group. The first, from Unit 80 , is of fine-grained quartzite. A portion of one barb is missing. It has a triangular blade with straight lateral edges which are serrated, prominent barbs, and a contracting stem with a gently convex base.

$\begin{array}{lllllll}\frac{\mathrm{T}}{3} & \frac{\mathrm{L}}{20} & \frac{\mathrm{MBW}}{15} & \frac{\mathrm{BW}}{3} & \frac{\mathrm{HL}}{5} & \frac{\mathrm{NW}}{5} & \frac{\mathrm{BD}}{0}\end{array}$

The second specimen, from Unit 96, is of yellow chert. The distal half of the blade is missing. It had a triangular blade with straight edges, prominent barbs, and a slightly contracting stem with a straight (possibly 
broken) base.

$\begin{array}{lllllll}\underline{\mathrm{T}} & \underline{\mathrm{L}} & \frac{\mathrm{MBW}}{20} & \frac{\mathrm{BW}}{3} & \frac{\mathrm{HL}}{5} & \frac{\mathrm{NW}}{4} & \frac{\mathrm{BD}}{0}\end{array}$

The third specimen, from Unit 100, is of dark gray

chert. It has a triangular blade with straight lateral edges, prominent outflaring barbs, and a contracting stem, offset from the blade, with a gently concave base.

$\begin{array}{lllllll}\frac{\mathrm{T}}{2} & \underline{\mathrm{L}} & \frac{\mathrm{MBW}}{17} & \frac{\mathrm{BW}}{2} & \frac{\mathrm{HL}}{2} & \frac{\mathrm{NW}}{5} & \frac{\mathrm{BD}}{5}\end{array}$

The fourth specimen, from Unit 67, is of silicified wood. It has an assymetrical blade with one convex edge and one concave edge, prominent unbarbed shoulders, and a contracting stem with a convex base.

\begin{tabular}{|c|c|c|c|c|c|c|}
\hline$\underline{T}$ & $\underline{I}$ & MBW & BW & $\mathrm{HL}$ & NW & $\mathrm{BD}$ \\
\hline 3 & 15 & 12 & 2 & 3 & 5 & \\
\hline
\end{tabular}

Untyped. There are 23 specimens which appear to be complete or fragmented arrow points that cannot be typed. Ten of these are so fragmentary that little of the original intended form can be determined. Some of these may be manufacturing failures. Of these ten, seven are of silicified wood, two are of chert, and one is of fine-grained quartzite. The remaining 13 specimens are described individually.

The first, from Unit 93, is of gray-brown chert. It has a long, slender triangular blade with recurved lateral edges; strong shoulders but no barbs; and a rectangular stem with a convex base. In blade form, this point resembles the type Hayes (Suhm and Jelks 1962: 277, P1. 139).

\begin{tabular}{|c|c|c|c|c|c|}
\hline$\underline{T}$ & L & MBW & BW & $\underline{\mathrm{HL}}$ & NW \\
\hline 3 & 41 & 14 & 3 & 7 & 5 \\
\hline
\end{tabular}


The second specimen, from Unit 98, is of finegrained quartzite. It has a long, slender triangular blade with straight to slightly convex, serrated lateral edges; prominent but assymetrical, outflaring barbs; and a slightly expanding stem with a convex base. This point vaguely resembles the Hayes type (Suhm and Jelks 1962: 277, P1. 139).

$\begin{array}{lllllll}\mathrm{T} & \mathrm{L} & \frac{\mathrm{MBW}}{8} & \frac{\mathrm{BW}}{6} & \frac{\mathrm{HL}}{7} & \frac{\mathrm{NW}}{6} & \frac{\mathrm{BD}}{-2}\end{array}$

The third specimen, from Unit 96, is of yellow and red banded chert. The stem and both shoulders are missing. The blade is long and slender with recurved serrated edges. This blade form resembles the type Hayes (Suhm and Jelks 1962: 81, P1. 139).

$\begin{array}{lllllll}\frac{\mathrm{T}}{3} & \underline{\mathrm{L}} & \frac{\mathrm{MBW}}{36+} & \mathrm{BW} & \text { HL } & \text { NW } & \text { BD }\end{array}$

The fourth specimen, from Unit 100, is of red chert. It has a small triangular blade with straight lateral edges which are serrated, prominent shoulders, and an expanding stem with a concave base.

$\begin{array}{lllllll}\frac{\mathrm{T}}{3} & \underline{\mathrm{L}} & \frac{\mathrm{MBW}}{14} & \mathrm{BW} & \frac{\mathrm{HL}}{7} & \frac{\mathrm{NW}}{5} & \frac{\text { BD }}{-1}\end{array}$

The fifth specimen, from Unit 66 , is of light gray to tan chert. One barb is missing. It has a triangular blade with straight edges, a prominent downward-pointing barb, and an expanding stem with a convex base.

$$
\begin{array}{lllllll}
\underline{\mathrm{T}} & \underline{\mathrm{L}} & \frac{\mathrm{MBW}}{20} & \frac{\mathrm{BW}}{7} & \frac{\mathrm{HL}}{3} & \frac{\mathrm{NW}}{6} & \frac{\mathrm{BD}}{-1}
\end{array}
$$

The sixth specimen, from Unit 68, is of silicified wood. One barb is missing. It has a small triangular blade with concave lateral edges, a small outflaring barb, and an 
expanding stem with a convex base.

\begin{tabular}{|c|c|c|c|c|c|c|}
\hline$\underline{T}$ & I & MBBW & BW & HL & NW & BD \\
\hline 3 & 15 & 12 & 7 & 4 & 6 & \\
\hline
\end{tabular}

The seventh specimen, from Unit 90 , is of silicified wood. The distal tip is missing. It has a slender triangular blade with one straight edge and one convex edge, weak shoulders, and a contracting stem with a convex base.

$\begin{array}{lllllll}\frac{\mathrm{T}}{4} & \underline{\mathrm{L}} & \frac{\mathrm{MBW}}{25} & \frac{\mathrm{BW}}{3} & \frac{\mathrm{HL}}{4} & \frac{\mathrm{NW}}{5} & \frac{\text { BD }}{-1}\end{array}$

The eighth specimen, from Unit 87 , is of finegrained quartzite. A portion of one barb is missing. It has a small triangular blade with straight lateral edges, a small squared outflaring barb, and a broad gently expanding stem with a concave base.

$\begin{array}{lllllll}\underline{\mathrm{T}} & \mathrm{L} & \frac{\mathrm{MBW}}{14} & \frac{\mathrm{BW}}{7} & \frac{\mathrm{HL}}{5} & \frac{\mathrm{NW}}{8} & \frac{\mathrm{BD}}{\mathrm{i}}\end{array}$

The ninth specimen, from Unit 69, is of fine-grained quartzite. The stem is missing. It has a roughly triangular blade with one straight edge and one convex edge (both are serrated) and small outflaring barbs.

\begin{tabular}{lllllll}
$\underline{\mathrm{T}}$ & $\underline{\mathrm{L}}$ & $\mathrm{MBW}$ & $\mathrm{BW}$ & $\mathrm{HL}$ & $\mathrm{NW}$ & BD \\
\hline & $18+$ & 13 & - & - & - & -
\end{tabular}

The tenth specimen, from Unit 67 , is of silicified wood. It has a triangular blade with straight edges, prominent shoulders, and a rectangular stem with a convex base.

\begin{tabular}{|c|c|c|c|c|c|c|}
\hline$\underline{\underline{T}}$ & $\underline{I}$ & MBW & BW & $\underline{\mathrm{HL}}$ & NW & $\underline{B D}$ \\
\hline 2 & 18 & 12 & 5 & 3 & 6 & \\
\hline
\end{tabular}

The eleventh specimen, also from Unit 67 , is of chert. It is extremely small and exhibits only unifacial 
flaking. It has a triangular blade with slightly concave lateral edges, well-defined shoulders, and a small contracting stem with a pointed base.

\begin{tabular}{|c|c|c|c|c|c|}
\hline $\mathrm{T}$ & $\underline{\mathrm{I}}$ & MBW & BW & $\underline{\mathrm{HL}}$ & $\underline{\mathrm{NW}}$ \\
\hline 1 & 11 & 9 & 1 & 2 & 3 \\
\hline
\end{tabular}

The twelfth specimen, from Unit 75, is also of chert. It is essentially triangular with minimal bifacial flaking on two edges. It is unstemmed.

\begin{tabular}{|c|c|c|c|c|c|}
\hline$\underline{T}$ & $\underline{L}$ & $\underline{\text { MBW }}$ & BW & $\underline{\mathrm{HL}}$ & $\underline{\mathrm{NW}}$ \\
\hline 2 & 15 & 8 & - & - & - \\
\hline
\end{tabular}

The thirteenth and final specimen, from Unit 88, is of fine-grained quartzite. It is quite small, lozenge-shaped, and shows minimal flaking.

$\begin{array}{lllllll}\underline{\mathrm{T}} & \mathrm{I} & \frac{\mathrm{MBW}}{4} & \frac{\mathrm{BW}}{2} & \frac{\mathrm{HL}}{4} & \underline{\mathrm{NW}} & \frac{\mathrm{BD}}{13}\end{array}$

\section{Awls (Table 10)}

Four bifacially-worked tools with sharply tapering points were recovered; one each came from Units 68, 88, 96 and 97. Two are of chert, one is of silicified wood, and one is of fine-grained quartzite. All but one of the specimens lack the distal tip. Two are stemmed and at least one of these is probably a reworked arrow point.

Other Bifaces (Table 10)

This category includes ten bifaces which appear to have been utilized as tools (based on the presence of pressure flaking and/or use wear) but which do not fit into any of the other bifacial tool categories. Four (three of silicified wood and one of coarse-grained quartzite) are very 
crudely chipped and are oval to subtriangular in outline. Lengths range from $38 \mathrm{~cm}$ to $59 \mathrm{~cm}$, maximum widths are 18-28 $\mathrm{cm}$, and maximum thicknesses range from 7 to $10 \mathrm{~cm}$. Three additional specimens (two of chert and one of coarse-grained quartzite) appear to be very fragmented portions of crudelychipped bifaces.

The remaining three specimens in this category are described individually because each is a complete, or nearly so, artifact and is relatively finely chipped. The first specimen is a long triangular biface of cream-colored chert. Lateral edges are mostly straight except for the distal onethird where they are convex. The base is slightly concave. This specimen was from Unit 105.

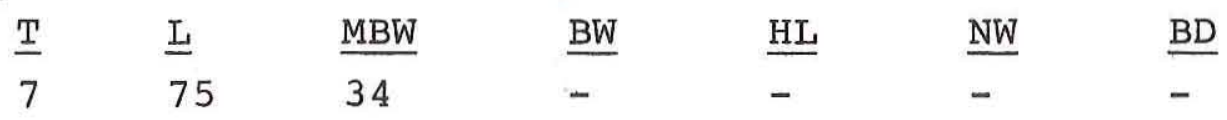

The second specimen, from Unit 85 , is of light gray chert. It is spatulate in outline with the original flake platform covering the proximal end. The edges are sinuous with occasional pressure flaking.

$\begin{array}{lllllll}\underline{T} & \underline{L} & \underline{\text { MBW }} & \text { BW } & \text { HL } & \text { NW } & \text { BD } \\ 9 & 52 & 49 & - & - & - & -\end{array}$

The final specimen, from Unit 108, is also of light gray chert. In outline, it is essentially rectangular with a convex distal end. The proximal portion of this artifact is broken off. The existing proximal end cross-section is bi-convex. The edges are moderately sinuous while the distal edge is extensively smoothed, perhaps from use as a scraper or gouge.

$\begin{array}{lllllll}\underline{T} & \underline{\mathrm{L}} & \underline{\mathrm{MBW}} & \underline{\mathrm{BW}} & \underline{\mathrm{HL}} & \underline{\mathrm{NW}} & \underline{\text { BD }} \\ 10 & 30 & 26 & - & - & - & -\end{array}$




\section{Biface Fragments (Table 10)}

This category includes seven small biface fragments which show pressure flaking and/or use wear but which are too fragmented to indicate the original tool form. Four are of chert, two are of fine-grained quartzite, and one is of silicified wood.

\section{Unifaces (Table 10)}

Two specimens, one each of silicified wood and ferruginous sandstone, show unifacial flaking along one edge. These artifacts are from Units 87 and 66 respectively.

Preforms (Table 10)

This category includes specimens which have been reduced to the general size and form of projectile points but which do not appear to be finished artifacts. None show use wear or pressure flaking. Many have been broken in manufacture or display obstinate cortex remnants which the knappers were unable to remove. These artifacts are classified as to intended final product (dart or arrow point) where these can be determined. The remaining preforms have been classified as "Other Biface." This latter category includes only core-derived preforms; it is likely that some, if not all of these, represent the early stages of dart point manufacture.

\section{Dart Point Preforms}

There are eight specimens in this category. Four are of fine-grained quartzite, one is of coarse-grained quartzite, one is of chert, and two are of silicified wood. 
Two appear to be preforms for contracting-stem forms, two appear to have rectangular stems, and four are of indeterminate stem form.

\section{Arrow Point Preforms}

The five preforms in this category, all fashioned on flakes, include two chert specimens, two fine-grained quartzite specimens, and one silicified wood specimen. One artifact has a contracting stem, one has a rectangular stem, and three have indeterminate stem forms.

\section{Other Biface Preforms}

This category includes nine artifacts. Five are of fine-grained quartzite, and four are of silicified wood.

Debitage (Tables 11-14)

The chipped stone debitage is classified by material and by stage of reduction. No attempt has been made to quantify the presence or absence of edge modification as adequate optical magnification was not available in the field. Such modification is certainly present, however. The raw material categories used here are chert, fine-grained quartzite, coarse-grained quartzite, silicified wood, and other silicious stone. This latter category includes three identified materials (Manning Fused Glass, novaculite and siltstone) which occur in very low frequencies and a few examples of unidentified materials.

The stage of reduction classification subdivides the debitage in each raw material group into eight categories: unmodified cobbles, cores, cortex flakes, partly 
TABLE 11

PROVENIENCE OF CHIPPED STONE DEBITAGE (CHERT)

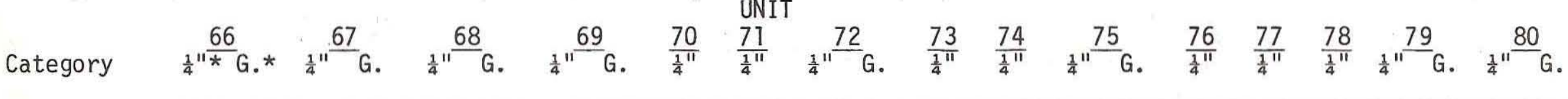

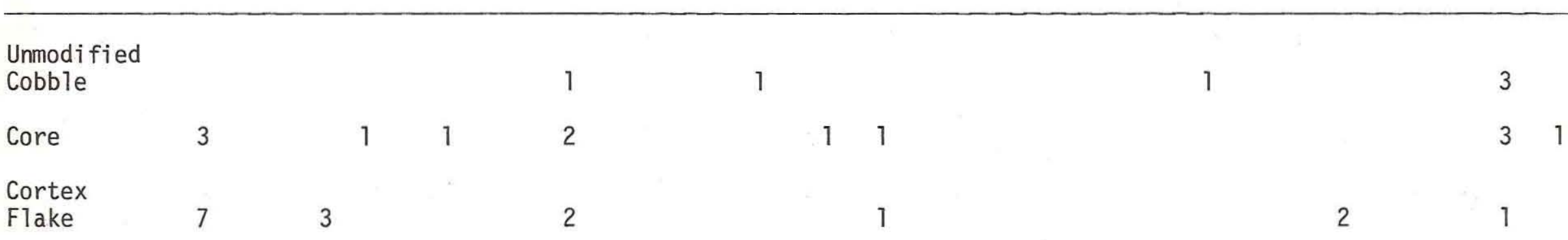

ô Partly

\begin{tabular}{|c|c|c|c|c|c|c|c|c|c|c|c|c|c|c|c|c|c|c|c|c|c|c|}
\hline $\begin{array}{l}\text { Decorticate } \\
\text { Flake }\end{array}$ & 22 & 4 & 6 & & 2 & & 6 & 1 & & & 2 & & 3 & 3 & 6 & 1 & 1 & & 2 & 5 & & 18 \\
\hline $\begin{array}{l}\text { Decorticate } \\
\text { Flake }\end{array}$ & 80 & 14 & 33 & 2 & 27 & 1 & 61 & 2 & 3 & 11 & 25 & 3 & 10 & 3 & 39 & 6 & & 5 & 3 & 32 & & 59 \\
\hline Cortex Chip & 2 & 1 & & & 2 & & 1 & & 1 & & & & & & & & & & & 1 & & 1 \\
\hline $\begin{array}{l}\text { Partiy } \\
\text { Decorticate } \\
\text { Chip }\end{array}$ & 26 & & 3 & 2 & 8 & & 3 & & & & 3 & & 2 & & & & 1 & & 1 & & & 9 \\
\hline $\begin{array}{l}\text { Decorticate } \\
\text { Chip }\end{array}$ & 69 & 7 & 21 & & 15 & & 32 & & & 4 & 14 & 3 & 9 & & 20 & & & 3 & 1 & 9 & 1 & 33 \\
\hline TOTAL: & 209 & 26 & 66 & 5 & 55 & 1 & 108 & 3 & 4 & 16 & 45 & 8 & 24 & 5 & 65 & 8 & 2 & 8 & 8 & 48 & 1 & 127 \\
\hline
\end{tabular}

$*_{\frac{1}{4}} "=$ screened material; G. = unscreened general fill. 
TABLE 11, Continued.

\begin{tabular}{|c|c|c|c|c|c|c|c|c|c|c|c|c|c|c|c|c|c|c|c|c|}
\hline & $\frac{81}{\frac{1}{4} 11}$ & $\frac{82}{\frac{111}{4}}$ & $\frac{1}{4}^{11}$ & & $\frac{1}{4} 1^{11}$ & & $\frac{85}{\frac{1}{4}}$ & $\frac{86}{\frac{1}{4} 11}$ & $\begin{array}{r}\text { UNIT } \\
\frac{87}{\frac{1}{4}}\end{array}$ & $\frac{1}{4} 1^{\varepsilon}$ & $\mathbb{8}_{G}$. & ${ }_{\frac{1}{4}}^{11}$ & $\underline{9}_{G}$. & $\frac{90}{\frac{111}{4}}$ & $\frac{91}{\frac{111}{4}}$ & & $2_{G}$. & $\frac{93}{\frac{111}{4}}$ & $\frac{94}{\frac{111}{4}}$ & $\frac{95}{G .}$ \\
\hline $\begin{array}{l}\text { Unmodified } \\
\text { Cobble }\end{array}$ & & & & & & & 1 & & & & & & & & & & & 1 & & \\
\hline Core & & & & & & & & & & 2 & & & & & & & & 1 & & \\
\hline $\begin{array}{l}\text { Cortex } \\
\text { Flake }\end{array}$ & & & & & & & & & & & & & & & & & & 2 & 1 & \\
\hline $\begin{array}{l}\text { Partly } \\
\text { Decorticate } \\
\text { Flake }\end{array}$ & & 1 & 1 & 1 & & & 2 & & 8 & 11 & 2 & 1 & & 1 & 2 & 4 & & 5 & 7 & \\
\hline $\begin{array}{l}\text { Decorticate } \\
\text { Flake }\end{array}$ & 6 & 2 & 32 & 5 & 3 & 2 & 15 & 11 & 38 & 32 & 3 & 10 & 1 & 10 & 6 & 10 & 1 & 27 & 42 & \\
\hline Cortex Chip & & & & & & & 1 & & 2 & 1 & & & & & & & & & & \\
\hline $\begin{array}{l}\text { Partly } \\
\text { Decorticate } \\
\text { Chip }\end{array}$ & & & & & & & 3 & 1 & & 2 & & & & 2 & 1 & 1 & & 2 & 7 & \\
\hline $\begin{array}{l}\text { Decorticate } \\
\text { Chip }\end{array}$ & 1 & 2 & 17 & 3 & 5 & & 5 & 9 & 16 & 9 & & 5 & & & 5 & 5 & & 13 & 34 & 1 \\
\hline TOTAL: & 7 & 5 & 50 & 9 & 8 & 2 & 27 & 21 & 64 & 57 & 5 & 16 & 1 & 13 & 14 & 20 & 1 & 51 & 91 & 1 \\
\hline
\end{tabular}


TABLE 11, Continued.

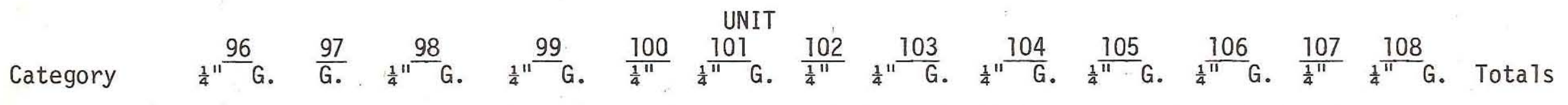

\begin{tabular}{|c|c|c|c|c|c|c|c|c|c|c|c|c|c|c|c|c|c|c|c|c|c|c|c|}
\hline $\begin{array}{l}\text { Unmodified } \\
\text { Cobble }\end{array}$ & 1 & 2 & & & & & & 1 & & & & & & & & & & & & & & & 12 \\
\hline Core & 2 & & & & & 1 & 1 & 1 & 2 & & & & & & & & & 1 & & & 1 & & 25 \\
\hline $\begin{array}{l}\text { Cortex } \\
\text { Flake }\end{array}$ & 5 & 2 & & & 1 & & & 1 & & & & & & & & & & & & & & & 28 \\
\hline $\begin{array}{l}\text { Partly } \\
\text { Decorticate } \\
\text { Flake }\end{array}$ & 24 & 4 & & 6 & & 1 & & 3 & 6 & & 2 & 1 & & 1 & & 2 & & & 1 & 3 & 4 & 1 & 188 \\
\hline $\begin{array}{l}\text { Decorticate } \\
\text { Flake }\end{array}$ & 73 & 6 & 3 & 61 & 6 & 55 & & 17 & 36 & 1 & 17 & 12 & 1 & 12 & & 24 & 1 & 9 & 1 & 17 & 4 & 10 & 1049 \\
\hline Cortex Chip & 14 & 1 & & & & 2 & & & & & & & & & & & & & & & & & 30 \\
\hline $\begin{array}{l}\text { Partly } \\
\text { Decorticate } \\
\text { Chip }\end{array}$ & 33 & 3 & & 3 & 1 & & & & & & & 1 & & & & & & & & 1 & & & 125 \\
\hline $\begin{array}{l}\text { Decorticate } \\
\text { Chip }\end{array}$ & 75 & 2 & 3 & 54 & ... & 32 & 1 & 15 & 22 & & 8 & 9 & & 9 & 1 & 16 & 1 & 8 & & 14 & 5 & 7 & 657 \\
\hline TOTAL: & 227 & 20 & 6 & 124 & 8 & 96 & 2 & 38 & 66 & 1 & 27 & 23 & 1 & 22 & 1 & 42 & 2 & 18 & 2 & 35 & 13 & 19 & 2114 \\
\hline
\end{tabular}


TABLE 12

PROVENIENCE OF CHIPPED STONE DEBITAGE (FINE-GRAINED QUARTZITE)

\begin{tabular}{|c|c|c|c|c|c|c|c|c|c|c|c|c|c|c|c|c|}
\hline \multirow{2}{*}{$\begin{array}{l}\text { Category } \\
\text { Unmodified } \\
\text { Cobble }\end{array}$} & \multicolumn{2}{|c|}{$\frac{66}{4} " \frac{66}{\star} \mathrm{G} . *$} & $\frac{67}{\frac{1}{4}^{11}}$ & \multirow[t]{2}{*}{ G. } & \multirow[t]{2}{*}{$\frac{68}{\frac{1111}{4}}$} & \multicolumn{2}{|c|}{$\frac{1}{4} 1{ }^{\prime \frac{69}{G}} \mathrm{G}}$. & \multirow[t]{2}{*}{$\begin{array}{l}\text { UNIT } \\
\frac{70}{\frac{111}{4}}\end{array}$} & \multirow[t]{2}{*}{$\frac{71}{\frac{111}{4}}$} & \multirow[t]{2}{*}{$\frac{72}{\frac{1}{4} 11}$} & \multicolumn{2}{|c|}{$\frac{1}{4} 1{ }^{73} \mathrm{G}}$. & \multirow[t]{2}{*}{$\frac{74}{\frac{111}{4}}$} & \multirow[t]{2}{*}{$\frac{75}{\frac{111}{4}}$} & \multirow[t]{2}{*}{$\frac{77}{\frac{111}{4}}$} & \multirow[t]{2}{*}{$\frac{78}{\frac{1}{4} 11}$} \\
\hline & & & 2 & & & & & & & & & & & & & \\
\hline Core & 4 & 1 & & & 1 & 2 & & & & & & & & & & \\
\hline $\begin{array}{l}\text { Cortex } \\
\text { Flake }\end{array}$ & 13 & & 2 & 1 & 1 & 3 & & & & & & & & & & \\
\hline $\begin{array}{l}\text { Partially } \\
\text { Decorticate } \\
\text { Flake }\end{array}$ & 28 & 7 & 13 & & 7 & 22 & 2 & 2 & 1 & 2 & 2 & & 2 & & & 1 \\
\hline $\begin{array}{l}\text { Decorticate } \\
\text { Flake }\end{array}$ & 43 & 3 & 14 & & 12 & 18 & & 1 & & 3 & & & 3 & 1 & 1 & 3 \\
\hline $\begin{array}{l}\text { Cortex } \\
\text { Chip }\end{array}$ & 6 & 1 & & & 1 & 1 & & & & & & & & & & \\
\hline $\begin{array}{l}\text { Partially } \\
\text { Decorticate } \\
\text { Chip }\end{array}$ & 24 & 1 & 5 & & 6 & 6 & & & & & 1 & & & & & \\
\hline $\begin{array}{l}\text { Decorticate } \\
\text { Chip }\end{array}$ & 27 & 3 & 8 & 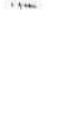 & 3 & 12 & & & & 1 & & 1 & & & & \\
\hline TOTAL: & 145 & 16 & 44 & 1 & 31 & 64 & 2 & 3 & 1 & 6 & 3 & 1 & 5 & 1 & 1 & 4 \\
\hline
\end{tabular}

$*_{\frac{1}{4}} "=$ screened material; G. = unscreened general fill. 
TABLE 12, Continued.

\begin{tabular}{|c|c|c|c|c|c|c|c|c|c|c|c|c|}
\hline Category & $\frac{1}{4} 1^{11}$ & $\underline{0}_{G}$. & $\frac{83}{G .}$ & $\frac{85}{\frac{111}{4}}$ & $\frac{86}{\frac{1}{4}^{11}}$ & $\frac{87}{\frac{1}{4} 11}$ & $\frac{88}{\frac{1}{4} 11}$ & $\frac{89}{\frac{111}{4}}$ & $\frac{90}{\frac{1}{4}}$ & $\frac{91}{\frac{111}{4}}$ & $\frac{92}{\frac{11^{11}}{11}}$ & $\frac{93}{\frac{1}{4}}$ \\
\hline $\begin{array}{l}\text { Unmodified } \\
\text { Cobble }\end{array}$ & 2 & & 1 & & & & 1 & & & & & \\
\hline Core & 4 & & & & & & & & & & & \\
\hline $\begin{array}{l}\text { Cortex } \\
\text { Flake }\end{array}$ & 5 & 1 & & 1 & & 2 & & & 1 & & 1 & \\
\hline $\begin{array}{l}\text { Partially } \\
\text { Decorticate } \\
\text { Flake }\end{array}$ & 34 & 1 & & & & 5 & 4 & & & 3 & 7 & 3 \\
\hline $\begin{array}{l}\text { Decorticate } \\
\text { Flake }\end{array}$ & 17 & 3 & & & 1 & 1 & 2 & 2 & 1 & 2 & 2 & 3 \\
\hline Cortex Chip & 4 & & & & & & & & & & & \\
\hline $\begin{array}{l}\text { Partially } \\
\text { Decorticate } \\
\text { Chip }\end{array}$ & 11 & & & & & 4 & & & & & 1 & 3 \\
\hline Decorticate Chip & 17 & & & & & 1 & & & & & 2 & 1 \\
\hline TOTAL: & 94 & 5 & 1 & 1 & 1 & 13 & 7 & 2 & 2 & 5 & 13 & 10 \\
\hline
\end{tabular}


TABLE 12, Continued.

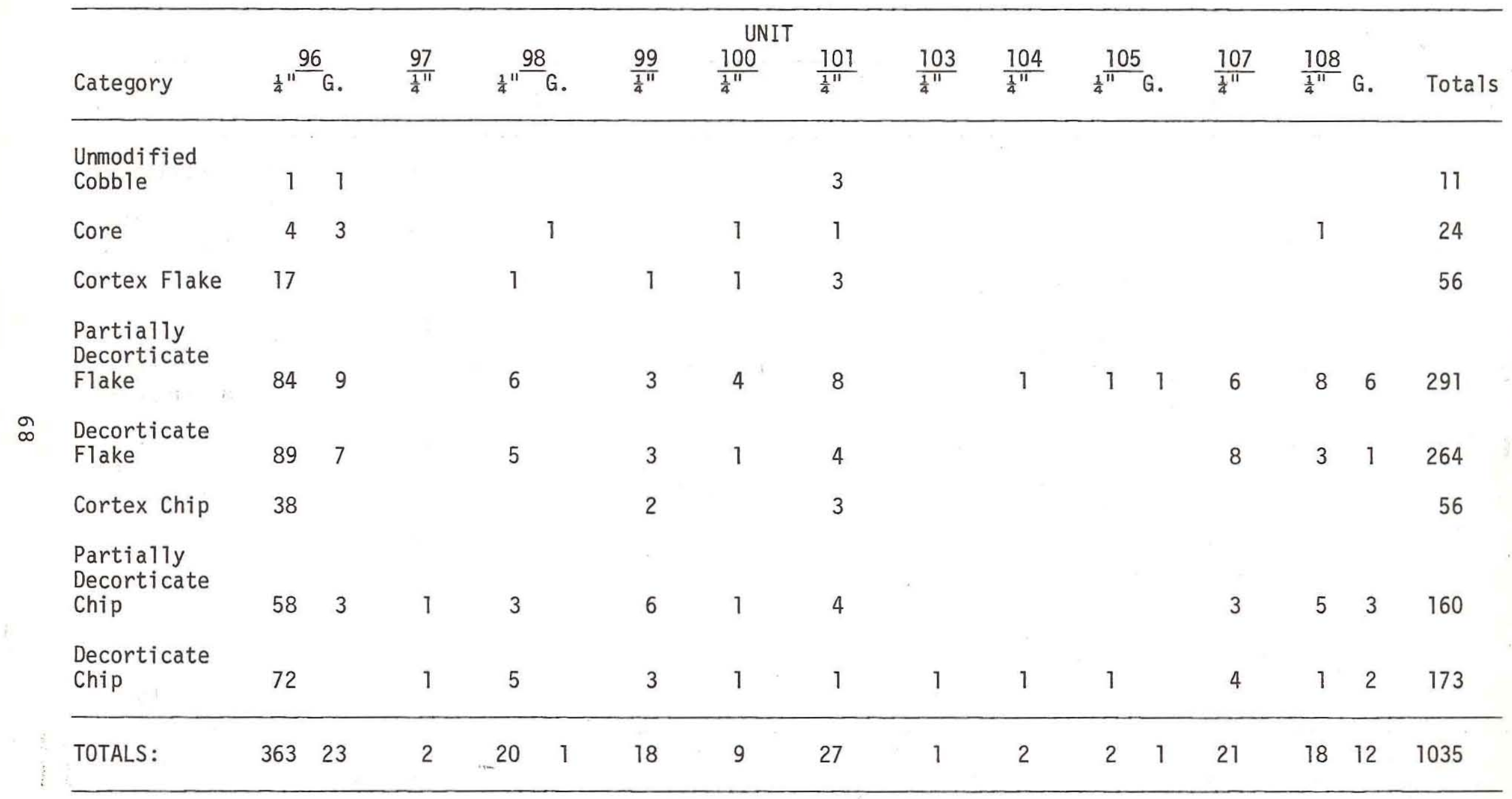


TABLE 13

PROVENIENCE OF CHIPPED STONE DEBITAGE (COARSE-GRAINED QUARTZITE)

\begin{tabular}{|c|c|c|c|c|c|c|c|c|c|c|c|c|c|c|c|c|}
\hline Category & $\frac{1}{4}^{11} \frac{66}{*}$ & & $\frac{1}{4}^{11}$ & & $\frac{68}{\frac{1}{4} 11}$ & $\frac{69}{\frac{111}{4}}$ & $\begin{array}{l}\text { UNIT } \\
\frac{70}{\frac{111}{4}}\end{array}$ & $\frac{72}{\frac{111}{4}}$ & $\frac{73}{\frac{1}{4} 11}$ & $\frac{74}{\frac{1}{4} 11}$ & $\frac{75}{\frac{1}{4} 11}$ & $\frac{77}{\frac{1}{4} 11}$ & & ${ }^{0}$ G. & $\frac{83}{G .}$ & $\frac{87}{\frac{1}{4}^{11}}$ \\
\hline $\begin{array}{l}\text { Unmodified } \\
\text { Cobble }\end{array}$ & 2 & & & & & & & & & 1 & & & 2 & 1 & 1 & \\
\hline Core & 2 & & & 1 & & 1 & & 1 & & & & & 4 & & & 1 \\
\hline Cortex Flake & & & & & & & & & & & & & 2 & & & \\
\hline $\begin{array}{l}\text { Partially } \\
\text { Decorticate } \\
\text { Flake }\end{array}$ & 6 & & & & 2 & 2 & & & & & & 1 & 8 & 1 & & \\
\hline $\begin{array}{l}\text { Decorticate } \\
\text { Flake }\end{array}$ & 11 & 2 & 1 & & 1 & 18 & 1 & 1 & & & & & 2 & & & \\
\hline Cortex Chip & & 1 & & & & 1 & & & & & 1 & & 2 & & & 1 \\
\hline $\begin{array}{l}\text { Partially } \\
\text { Decorticate } \\
\text { Chip }\end{array}$ & 1 & & & & & 2 & 1 & & & & & & 2 & & & \\
\hline $\begin{array}{l}\text { Decorticate } \\
\text { Chip }\end{array}$ & 7 & & & & 1 & 6 & & & 1 & & & & 3 & 1 & & \\
\hline TOTAL: & 29 & 3 & 1 & 1 & 4 & 30 & 2 & 2 & 1 & 1 & 1 & 1 & 25 & 3 & 1 & 2 \\
\hline
\end{tabular}

$*_{\frac{1}{4}} \|=$ screened material; G. = unscreened general fill. 
TABLE 13, Continued.

\begin{tabular}{|c|c|c|c|c|c|c|c|c|c|c|c|c|c|c|c|c|}
\hline \multirow[b]{2}{*}{ Category } & \multirow[b]{2}{*}{$\frac{88}{\frac{1}{4} 11}$} & \multirow[b]{2}{*}{$\frac{91}{\frac{111}{4}}$} & \multirow[b]{2}{*}{$\frac{92}{\frac{111}{4}}$} & \multirow[b]{2}{*}{$\frac{93}{\frac{111}{4}}$} & \multirow[b]{2}{*}{$\frac{94}{\frac{111}{4}}$} & \multicolumn{3}{|c|}{ UNIT } & \multirow{2}{*}{\multicolumn{2}{|c|}{99}} & \multirow[b]{2}{*}{$\frac{100}{\frac{101}{4}}$} & \multirow[b]{2}{*}{$\frac{101}{\frac{101}{4}}$} & \multirow[b]{2}{*}{$\frac{105}{\frac{111}{4}}$} & \multirow[b]{2}{*}{$\frac{107}{\frac{107}{4}}$} & \multirow[b]{2}{*}{$\frac{108}{G .}$} & \multirow{2}{*}{ Totals } \\
\hline & & & & & & $\frac{1}{4} 11$ & $\frac{36}{G .}$ & $\frac{98}{\frac{111}{4}}$ & & & & & & & & \\
\hline \multirow{2}{*}{$\begin{array}{l}\text { Unmodified } \\
\text { Cobble }\end{array}$} & & & & & & & & & & & & & & & & \\
\hline & & & & & & 1 & 1 & & & & & & 1 & & & 10 \\
\hline Core & 3 & 2 & & & & & & & & & 1 & & & 1 & & 17 \\
\hline Cortex Flake & & & & & & & & & & & & 1 & & & & 3 \\
\hline $\begin{array}{l}\text { Partially } \\
\text { Decorticate }\end{array}$ & & & & & & & & & & & & & & & & \\
\hline Flake & 6 & & 1 & & & 14 & 2 & & 1 & & & 9 & & & 2 & 55 \\
\hline $\begin{array}{l}\text { Decorticate } \\
\text { Flake }\end{array}$ & 1 & & 1 & 1 & 2 & 268 & 31 & 2 & & 1 & 1 & 6 & & 13 & 1 & 365 \\
\hline Cortex Chip & & & & & 1 & 6 & & & & & & & & & & 13 \\
\hline $\begin{array}{l}\text { Partially } \\
\text { Decorticate }\end{array}$ & & & & & & & & & & & & & & & & \\
\hline Chip & 1 & & 1 & & 1 & 15 & 2 & & & & & & & & & 26 \\
\hline Decorticate & & & & & & & & & & & & & & & & \\
\hline Chip & & & & 2 & & 232 & 17 & 2 & 1 & & 3 & 4 & & 6 & & 286 \\
\hline TOTAL: & 11 & 2 & 3 & 3 & 4 & 536 & 53 & 4 & 2 & 1 & 5 & 20 & 1 & 20 & 3 & 775 \\
\hline
\end{tabular}


TABLE 14

PROVENIENCE OF CHIPPED STONE DEBITAGE (SILICIFIED WOOD AND OTHER MATERIALS)

\begin{tabular}{|c|c|c|c|c|c|c|c|c|c|c|c|c|c|c|c|c|c|c|}
\hline \multirow{2}{*}{$\begin{array}{l}\text { Category } \\
\text { Silicified Wood: } \\
\text { Unmod. Cobble }\end{array}$} & \multicolumn{2}{|c|}{$\frac{12}{4} \stackrel{\frac{66}{*}}{G_{0} *}$} & \multicolumn{2}{|c|}{$\frac{1}{4} " \frac{67}{G .}$} & $\frac{68}{\frac{1}{4} 11}$ & \multicolumn{2}{|c|}{$\begin{array}{r}\text { UNIT } \\
69\end{array}$} & $\frac{71}{\frac{1}{4} 11}$ & $\frac{72}{\frac{11}{4}}$ & \multicolumn{2}{|c|}{$\frac{73}{4} \stackrel{73}{G .}$} & \multicolumn{2}{|c|}{$\underline{75}$} & $\frac{78}{\frac{1}{4}}$ & $\frac{79}{\frac{1}{4} 11}$ & \multicolumn{2}{|c|}{$\frac{80}{4}=\frac{11}{G .}$} & $\frac{81}{\frac{1}{4} 11}$ \\
\hline & & & & & & & & & & & & & & & & 2 & & \\
\hline Core & 2 & & 1 & & & 3 & & & 1 & 1 & & & & & & 1 & 2 & \\
\hline Cortex Flake & 3 & & & & 1 & 4 & & & 2 & & & & & 1 & 2 & 6 & & \\
\hline $\begin{array}{l}\text { Partially Decor- } \\
\text { ticate Flake }\end{array}$ & 28 & 2 & 23 & 1 & 21 & 33 & 4 & 2 & 7 & 3 & & 3 & 2 & & 6 & 47 & 5 & 1 \\
\hline Decorticate Flake & 23 & 1 & 21 & & 8 & 23 & 2 & 2 & 3 & & & & & 1 & 2 & 34 & 1 & \\
\hline Cortex Chip & 11 & 2 & 1 & & 3 & 4 & & & 1 & & & & & & & 7 & & \\
\hline $\begin{array}{l}\text { Partially Decor- } \\
\text { ticate Chip }\end{array}$ & 30 & & 7 & & 11 & 32 & & & 2 & 3 & & 6 & & & 1 & 27 & 2 & 1 \\
\hline Decorticate Chip & 31 & 1 & 18 & 2 & 11 & 12 & & 1 & 1 & 2 & 1 & & & & 2 & 34 & 3 & \\
\hline Subtotals & 128 & 6 & 71 & 3 & 55 & 111 & 6 & 5 & 17 & 9 & 1 & 9 & 2 & 2 & 13 & 158 & 13 & 1 \\
\hline $\begin{array}{l}\text { Other Materials: } \\
\text { Partly Decorti- } \\
\text { cate Flake }\end{array}$ & & & & & & & & & & & & 1 & & & & & & \\
\hline Decorticate Flake & 6 & & 1 & 1 & & & & & & & & 1 & & & & 2 & & \\
\hline $\begin{array}{l}\text { Partly Decorti- } \\
\text { cate Chip }\end{array}$ & 3 & & " & & & & & & & & & 1 & & & & & & \\
\hline Decorticate Chip & 2 & & & & 1 & & & & & & & & & & 1 & 3 & & \\
\hline Subtotals & 11 & & 1 & 1 & 1 & & & & & & & 3 & & & 1 & 5 & & \\
\hline TOTAL: & 139 & 6 & 72 & 4 & 56 & 111 & 6 & 5 & 17 & 9 & 1 & 12 & 2 & 2 & 14 & 163 & 13 & 1 \\
\hline
\end{tabular}

$\star_{\frac{1}{4}} "=$ screened material; G. = unscreened general fill. 
TABLE 14, Continued.

\begin{tabular}{|c|c|c|c|c|c|c|c|c|c|c|c|c|c|c|c|c|}
\hline Category & $\frac{82}{\frac{111}{4}}$ & $\frac{1}{4}{ }^{11}$ & $\frac{3}{G .}$ & $\frac{85}{\frac{111}{4}}$ & $\frac{86}{\frac{1}{4}^{11}}$ & $\begin{array}{l}\text { UNIT } \\
\frac{87}{\frac{1}{4}^{11}}\end{array}$ & $\frac{88}{\frac{1}{4} 11}$ & & $\stackrel{9}{G}_{\text {G. }}$. & $\frac{90}{\frac{111}{4}}$ & $\frac{91}{\frac{1}{4} 11}$ & $\frac{92}{\frac{1}{4} 11}$ & $\frac{93}{\frac{111}{4}}$ & $\frac{94}{\frac{114}{4}}$ & & $\frac{6}{G}$. \\
\hline $\begin{array}{l}\text { Silicified Wood: } \\
\text { Unmod. Cobble }\end{array}$ & & & & 1 & & & & & & & & & & & & 2 \\
\hline Core & & & & & & & 1 & & & & & 1 & 1 & & 3 & 3 \\
\hline Cortex Flake & & & & & & & 3 & & & & & & 1 & 3 & 12 & \\
\hline $\begin{array}{l}\text { Partially Decorti- } \\
\text { cate Flake }\end{array}$ & & 2 & & & & 3 & 13 & 3 & & 6 & 7 & 6 & 8 & 5 & 40 & 7 \\
\hline Decorticate Flake & 2 & & 1 & 1 & 1 & 12 & 10 & 1 & & & 6 & 3 & & 5 & 53 & 1 \\
\hline Cortex Chips & & & & & & & & & & 1 & & & 1 & & 31 & 1 \\
\hline $\begin{array}{l}\text { Partially Decorti- } \\
\text { cate Chip }\end{array}$ & 1 & 2 & & & & 6 & 9 & 2 & & & & 5 & 5 & 14 & 55 & 1 \\
\hline Decorticate Chip & & 1 & & 1 & & 4 & 8 & & 1 & 2 & 2 & & 4 & 7 & 53 & 1 \\
\hline Subtotals & 3 & 5 & 1 & 3 & 1 & 25 & 44 & 6 & 1 & 9 & 15 & 15 & 20 & 34 & 247 & 17 \\
\hline $\begin{array}{l}\text { Other Materials: } \\
\text { Partly Decorti- } \\
\text { cate Flake }\end{array}$ & 1 & & & & & 1 & & & & & & & & & & \\
\hline Decorticate Flake & & & & & & & & & & & & & & & 1 & \\
\hline $\begin{array}{l}\text { Partly Decorti- } \\
\text { cate Chip }\end{array}$ & & & & & & & & & & & & & & & & 1 \\
\hline Decorticate Chip & 1 & & & & & & & & & & & & & & 1 & \\
\hline Subtotals & 2 & & & & & 1 & & & & & & & & & 2 & 1 \\
\hline TOTAL: & 5 & 5 & .1 & 3 & 1 & 26 & 44 & 6 & 1 & 9 & 15 & 15 & 20 & 34 & 249 & 18 \\
\hline
\end{tabular}


TABLE 14, Continued.

\begin{tabular}{|c|c|c|c|c|c|c|c|c|c|c|c|c|c|c|c|c|}
\hline Category & $\frac{97}{G .}$ & $\frac{1}{4} 1^{\frac{9}{9}}$ & $\stackrel{8}{G}$. & $\frac{1}{4} " \frac{9}{1}$ & $\frac{9}{G .}$ & $\frac{100}{\frac{1}{4}^{11}}$ & $\begin{array}{l}\text { UNIT } \\
\frac{101}{\frac{101}{4}}\end{array}$ & $\frac{102}{\frac{1}{4} " 1}$ & $\frac{103}{\frac{111}{4}}$ & $\frac{104}{\frac{111}{4}}$ & $\frac{105}{\frac{1011}{4}}$ & $\frac{106}{\frac{111}{4}}$ & $\frac{107}{\frac{107}{4}}$ & $\frac{10}{\frac{1}{4}^{11}}$ & $\frac{8}{G}$. & Totals \\
\hline $\begin{array}{l}\text { Silicified Wood: } \\
\text { Unmod. Cobble }\end{array}$ & & & & & & & & & & & & & & & & 5 \\
\hline Core & & 1 & & & & & 7 & & & & & & 1 & 1 & & 30 \\
\hline Cortex Flake & & 4 & & 3 & & & 3 & & & & 1 & & & & & 49 \\
\hline $\begin{array}{l}\text { Partially Decorti- } \\
\text { cate Flake }\end{array}$ & 1 & 26 & 1 & 7 & 1 & 8 & 16 & 1 & & & 3 & & 8 & 21 & & 363 \\
\hline Decorticate Flake & & 9 & & 10 & & 7 & 12 & & 3 & 1 & 2 & & 12 & 1 & 3 & 275 \\
\hline Cortex Chips & & 1 & & & & & & & & & & & & & 1 & 65 \\
\hline $\begin{array}{l}\text { Partially Decor- } \\
\text { ticate Chip }\end{array}$ & & 10 & & 8 & & 4 & 19 & 1 & 1 & & 1 & 2 & 12 & 2 & 4 & 286 \\
\hline Decorticate Chip & & 9 & 3 & 9 & & 3 & 6 & 2 & 3 & & & 1 & 10 & 1 & 3 & 253 \\
\hline Subtotals & 1 & 60 & 4 & 37 & 1 & 22 & 63 & 4 & 7 & 1 & 7 & 3 & 43 & 7 & 12 & 1326 \\
\hline $\begin{array}{l}\text { Other Materials: } \\
\text { Partly Decorti- } \\
\text { cate Flake }\end{array}$ & & & & & & & & & & & & & & & & 3 \\
\hline Decorticate Flake & & & & & & & & & & & & & 1 & 1 & & 14 \\
\hline $\begin{array}{l}\text { Partly Decorti- } \\
\text { cate Chip }\end{array}$ & & & & & & & & & & & & & & & & 5 \\
\hline Decorticate Chip & 1 & & $\ldots$ & 2 & & & & & & & & & 1 & & & 13 \\
\hline Subtotals & 1 & & & 2 & & & & & & & & & 2 & 1 & & 35 \\
\hline TOTAL: & 2 & 60 & 4 & 39 & 1 & 22 & 63 & 4 & 7 & 1 & 7 & 3 & 45 & 8 & 12 & 1361 \\
\hline
\end{tabular}


decorticate flakes, decorticate flakes, cortex chips, partly decorticate chips, and decorticate chips.

Unmodified cobbles are stones of materials used in chipped stone manufacture which show no signs of aboriginal modification. It is presumed that these cobbles were transported to the site for use in lithic manufacture but were never utilized. Cores are stones from which flakes have been removed and which show no signs of having been removed from stones larger than themselves. Flakes are separated from chips on the basis of the presence of the striking platform. Cortex flakes and chips have ca. 90\% or more of their dorsal surfaces covered with cortex. Partially decorticate flakes and chips have some cortex (but less than 90\%) on their dorsal surfaces. Decorticate flakes and chips have no cortex at all on their dorsal surface.

Stage of reduction and detailed raw material analyses are not attempted here. However, very limited conclusions included in the discussion at the end of this chapter can be derived from a brief examination of the raw material data (Tables 11-14).

Abraded, Pecked and Battered Stone (Table 15) This reduction technique category contains 298 specimens. These are divided into descriptive categories but functions are inferred for some.

Tools

Abraded Slabs

This category includes two specimens of ferruginous sandstone which are relatively large, thick and tabular. 


\section{TABLE 15}

PROVENIENCE OF ABRADED, PECKED, BATTERED, AND POLISHED STONE

\begin{tabular}{|c|c|c|c|c|c|c|c|c|c|c|c|c|c|c|c|c|c|c|c|c|c|}
\hline Category & $\frac{1}{4} 11 \frac{66}{*}$ & $\frac{5}{G . *}$ & $\frac{67}{\frac{1^{4}}{4}}$ & $\frac{68}{\frac{1}{4} 11}$ & $\frac{1}{4} 116$ & $\underline{9}_{G}$. & $\frac{11}{4} 1^{72}$ & ${ }^{2}$. & $\frac{73}{\frac{11^{11}}{1}}$ & $\begin{array}{l}\text { UNIT } \\
\frac{74}{\frac{1}{4}^{11}}\end{array}$ & $\frac{1}{4} 11$ & $\stackrel{5}{G}$. & $\frac{78}{\frac{1}{4}^{11}}$ & $\frac{79}{\frac{1}{4} 11}$ & & G. & $\frac{81}{\frac{1}{4}{ }^{11}}$ & $\frac{83}{\frac{1}{4}{ }^{11}}$ & $\frac{85}{\frac{1}{4}}$ & $\frac{87}{\frac{1}{4} 11}$ & $\frac{88}{\frac{1}{4}{ }^{11}}$ \\
\hline Abraded Slabs & & 1 & & & & & & & & & & 1 & & & & & & & & & \\
\hline $\begin{array}{l}\text { Amorphous } \\
\text { Abraders }\end{array}$ & 4 & & & & 2 & & & & & 1 & 1 & & 1 & 1 & & & & & & 1 & 1 \\
\hline $\begin{array}{l}\text { Tabular } \\
\text { Abraders }\end{array}$ & 2 & & & & & & & 1 & & & & & & & 3 & & & 1 & & & \\
\hline $\begin{array}{l}\text { Grooved } \\
\text { Abraders }\end{array}$ & & & & & & & & & & & & & & & 1 & & & & 1 & & 1 \\
\hline $\begin{array}{l}\text { Unclassifiable } \\
\text { Abrader Frags. }\end{array}$ & 1 & & & & 1 & & & & & & & & & & 4 & 1 & & & & & \\
\hline Pitted Stones & & 2 & 2 & 1 & & & & 1 & & & & & 1 & & & & & & & & \\
\hline $\begin{array}{l}\text { Flakes and } \\
\text { Fragments }\end{array}$ & 37 & 6 & 10 & 1 & 9 & 1 & 6 & & 1 & & 4 & & & 5 & 55 & & & . & & 3 & 9 \\
\hline Subtotals & 44 & 9 & 12 & 2 & 12 & 1 & 6 & 2 & 1 & 1 & 5 & 1 & 2 & 6 & 63 & 1 & & 1 & 1 & 4 & 11 \\
\hline Battered Cobbles & & & & 2 & & & & & & & 1 & & & & & 1 & 1 & & & & \\
\hline Celt Fragments & & & 1 & & & & & & & & & & & & & & & & & & \\
\hline TOTAL: & 44 & 9 & 13 & 4 & 12 & 1 & 6 & 2 & 1 & 1 & 6 & 1 & 2 & 6 & 63 & 2 & 1 & 1 & 1 & 5 & 11 \\
\hline
\end{tabular}

$\star_{\frac{1}{4}}{ }^{\prime \prime}=$ screened material; G. = unscreened general fill. 
TABLE 15, Continued.

\begin{tabular}{|c|c|c|c|c|c|c|c|c|c|c|c|c|c|c|c|c|c|c|c|c|c|c|}
\hline \multirow[b]{2}{*}{ Category } & \multirow[b]{2}{*}{$\frac{89}{\frac{1}{4}^{11}}$} & \multirow[b]{2}{*}{$\frac{91}{\frac{111}{4}}$} & \multirow[b]{2}{*}{$\frac{92}{\frac{111}{4}}$} & \multirow[b]{2}{*}{$\frac{93}{\frac{1}{4}{ }^{11}}$} & \multirow[b]{2}{*}{$\frac{94}{\frac{1}{4} 11}$} & \multicolumn{2}{|c|}{96} & \multicolumn{4}{|c|}{ UNIT } & \multirow[b]{2}{*}{$\frac{99}{\frac{1}{4} 11}$} & \multirow[b]{2}{*}{$\frac{100}{\frac{1}{4} 11}$} & \multirow[b]{2}{*}{$\frac{101}{\frac{1}{4} 11}$} & \multirow[b]{2}{*}{$\frac{102}{\frac{1}{4}{ }^{11}}$} & \multirow[b]{2}{*}{$\frac{103}{\frac{1}{4}{ }^{11}}$} & \multirow[b]{2}{*}{$\frac{105}{\frac{10}{4} " 1}$} & \multirow[b]{2}{*}{$\frac{106}{\frac{1}{4} 1^{11}}$} & \multirow[b]{2}{*}{$\frac{107}{\frac{11}{4}}$} & \multirow{2}{*}{\multicolumn{2}{|c|}{$\frac{108}{111}$}} & \multirow[b]{2}{*}{. Totals } \\
\hline & & & & & & $\frac{1}{4} 1{ }^{\prime \prime}$ & $\underline{6}_{G}$. & $\frac{1}{4} 119$ & 97. & & $\frac{8}{G}$. & & & & & & & & & & & \\
\hline Abraded Slabs & & & & & & & & & & & & & & & & & & & & & & 2 \\
\hline $\begin{array}{l}\text { Amorphous } \\
\text { Abraders }\end{array}$ & 1 & 1 & & & & & 5 & & 1 & & & & 1 & & & & 1 & 2 & & 1 & 1 & 26 \\
\hline $\begin{array}{l}\text { Tabular } \\
\text { Abraders }\end{array}$ & & 2 & & & & 2 & & & & & & & & & & & & & & 1 & & 12 \\
\hline $\begin{array}{l}\text { Grooved } \\
\text { Abraders }\end{array}$ & 1 & & & & & & & & & & & & & & & & & & & & & 4 \\
\hline $\begin{array}{l}\text { Unclassifiable } \\
\text { Abrader Frags. }\end{array}$ & & & 1 & & & & 2 & & & & & & & & & & & & & & & 10 \\
\hline Pitted Stones & 1 & 1 & 1 & & 1 & 1 & & & 1 & 1 & & & & & 1 & & & & & & & 15 \\
\hline $\begin{array}{l}\text { Flakes and } \\
\text { Fragments }\end{array}$ & 4 & 1 & 1 & 1 & 4 & 19 & 4 & 2 & 2 & 2 & 2 & 3 & 1 & 18 & 1 & 1 & 2 & & 2 & 1 & 4 & 222 \\
\hline Subtotals & 7 & 5 & 3 & 1 & 5 & 22 & 11 & 2 & 4 & 3 & 2 & 3 & 2 & 18 & 2 & 1 & 3 & 2 & 2 & 3 & 5 & 291 \\
\hline Battered Cobbles & & & & & & 1 & & & 1 & & & & & & & & & & & & & 7 \\
\hline Celt Fragments & & & & & & 1 & & & & & & & & & & & & & & & & 2 \\
\hline TOTAL: & 7 & 5 & 3 & 1 & 5 & 24 & 11 & 2 & 5 & 3 & 2 & 3 & 2 & 18 & 2 & 1 & 3 & 2 & 2 & 3 & 5 & 300 \\
\hline
\end{tabular}


These appear to have been used for grinding in combination with a smaller, hand-held stone and thus probably correspond, at least in presumed function, to shafer's grinding slabs (Shafer 1973: 319).

\section{Amorphous Abraders}

This category includes 26 specimens which are of irregular shape and varying sizes and which show one or more abraded surfaces. Twenty-five are of ferruginous sandstone and one is of coarse-grained quartzite.

\section{Tabular Abraders}

Included in this category are 12 small, thin pieces of ferruginous sandstone with planar, abraded surfaces on one or both faces.

\section{Ground Abraders}

Four irregularly-shaped cobbles exhibit one or more shallow, linear, U-shaped, abraded grooves. All are of ferruginous sandstone.

\section{Unclassifiable Abrader Fragments}

This category includes ten specimens which are generally small and show one or more remnants of abraded surfaces but which are too fragmented to further classify. All are of ferruginous sandstone.

\section{Pitted Stones}

The 15 artifacts in this group are cobbles which are generally oval or subrectangular in shape and which have a 
pecked and/or abraded pit in the center of one or both faces. One or both of these faces is usually abraded to give a smooth surface, and the edges of the cobble are often pecked and/or abraded. All of these are of ferruginous sandstone.

\section{Battered Cobbles}

Included here are seven cobbles which have been heavily battered on one or more surfaces, presumably through use as a hammerstone. Five are of coarse-grained quartzite, and two are of fine-grained quartzite.

\section{Flakes and Fragments}

This category contains 222 pieces of sandstone which are presumed to reflect the debitage of deliberate shaping in abraded tool preparation. All but five of these specimens are of local ferruginous sandstone. The remaining five (one from Unit 72, one from Unit 80, two from Unit 96, and one from Unit 105) are of Catahoula Sandstone, a white to pale gray sandstone which can be obtained ca. 70 kilometers to the south of the Davis Site.

\section{Polished Stone (Table 15)}

\section{Celt Fragments}

The only polished stone artifacts recovered in these investigations are two small celt fragments (one each from Units 67 and 96). One is a bit fragment and the other a body fragment. Two celts are represented. The fragments are too small for definite determinations of shape, but both seem to have come from petaloid celts. The bit fragment is of a dark greenish-gray metamorphic material while 
the body fragment is of a dark gray, fine-textured, indurated sandstone. Both materials appear to be nonlocal in origin.

\section{Unmodified Pebbles}

Included here are 41 unmodified pebbles (see Table 18). All are stream-worn, and most are less than $1 \mathrm{~cm}$ in diameter. A few are of chert, but most are quartz. The origin and use of these specimens are not known; however, it seems likely that they were intentionally transported to the site.

\section{Discussion of Lithics}

The lithics collected during these investigations comprise a large body of data which, if given the proper attention, should provide a wealth of information concerning this portion of the Davis Site. Unfortunately, time limitations allow only the highlighting of a few of the collection's most obvious aspects.

The projectile points recovered (Table 10) generally support the chronological picture provided by the ceramics. That is, they suggest pre-Caddoan (represented by the dart points) and Late Caddoan (represented by at least the Perdiz and Friley arrow points) occupations. Only a single arrow point is of the Alba type so common in the Davis Site Alto Focus collections. The contracting-stem dart points, along with the sandy-paste pottery, probably indicate a Late Archaic component while the expanding-stem dart points may represent earlier Archaic occupations (although this remains to be demonstrated).

The chipped stone debitage is rather significant in terms of the occurrence of raw materials when compared with 
previous Davis Site collections (Table 16). The obvious difference between this collection and previous Davis Site debitage collections is the relatively low percentage of chert. Creel, in dealing with the 1978 Texas A\&M collection, argues rather convincingly that a low chert debitage percentage at this site is indicative of pre-Caddoan components (Creel 1979: 144-152). The present collection may well indicate relatively intensive Archaic occupations within the project area. However, it should be noted that creel's model is based on a comparison of pre-Caddoan and (primarily) Early Caddoan assemblages; this model may need to be altered in order to properly consider the characteristics of late Caddoan lithics.

This model is supported, however, by the distributions of debitage raw material classes, dart points/dart point preforms, and sandy-paste pottery within the 1980 project area (Table 17).

Table 17 shows that the units with the highest chert debitage percentages generally lack dart points and sandy-paste ceramics; both traits are considered to be hallmarks of pre-Caddoan occupations. This definitely suggests that there is a co-variation between the occurrence of Archaic artifacts and comparatively high percentages of quartzite and silicified wood debitage.

Table 17 concurrently demonstrates a significant pattern in the horizontal distributions of these artifact classes. Specifically, the five units $(83,75,105,79$ and 72) with the least amounts of pre-Caddoan materials (dart points, sandy-paste pottery and silicified wood and quartzite debitage) are all in the northern and northwestern portions of Area 1 (see Figure 3). This indicates the 
TABLE 16

PERCENTAGE OF LITHIC DEBITAGE BY RAW MATERIAL

\begin{tabular}{lccccc}
\hline Collections & $1968-70$ & 1977 & 1978 (Texas A\&M) & 1978 (UT) & 1980 \\
\hline $\begin{array}{l}\text { Chert } \\
\begin{array}{l}\text { Fine-Grained } \\
\text { Quartzite }\end{array}\end{array}$ & $62.30 \%(4267)$ & $73.83 \%(316)$ & $63.04 \%(3021)$ & $84.16 \%(765)$ & $40.00 \%(2114)$ \\
$\begin{array}{l}\text { Coarse-Grained } \\
\text { Quartzite }\end{array}$ & & & $16.92 \%(811)$ & $19.58 \%(1035)$ \\
TOTAL QUARTZITE & $21.23 \%(1456)$ & $10.28 \%(44)$ & $13.76 \%(1139)$ & $7.37 \%(67)$ & $34.24 \%(1810)$ \\
$\infty$ & $9.18 \%(630)$ & $15.65 \%(67)$ & $12.52 \%(600)$ & $6.82 \%(62)$ & $25.04 \%(1326)$ \\
Silicified Wood & $7.37 \%(1)$ & $0.23 \%(1)$ & $0.67 \%(32)$ & $1.65 \%(15)$ & $0.66 \%(35)$
\end{tabular}


TABLE 17

RANKING OF UNITS* BY PERCENTAGE OF CHERT DEBITAGE

\begin{tabular}{|c|c|c|c|}
\hline Unit & \% Chert & $\begin{array}{l}\text { Presence of Dart } \\
\text { Points/Preforms }\end{array}$ & $\begin{array}{l}\text { Presence of Sandy- } \\
\text { Paste Pottery }\end{array}$ \\
\hline 83 & 88.06 & & \\
\hline 75 & 82.02 & & + \\
\hline 105 & 80.00 & & \\
\hline 79 & 77.78 & + & \\
\hline 72 & 67.95 & & \\
\hline 99 & 61.64 & & \\
\hline 87 & 60.95 & + & + \\
\hline 93 & 60.71 & & + \\
\hline 98 & 59.73 & + & + \\
\hline 94 & 56.17 & & + \\
\hline 100 & 51.35 & + & \\
\hline 88 & 50.00 & + & + \\
\hline 66 & 41.01 & + & + \\
\hline 92 & 40.38 & + & \\
\hline 68 & 38.10 & + & + \\
\hline 101 & 37.85 & & + \\
\hline 108 & 37.65 & & \\
\hline 67 & 36.60 & + & + \\
\hline 69 & 34.26 & + & + \\
\hline 80 & 32.08 & + & + \\
\hline 107 & 28.93 & & \\
\hline 96 & 16.59 & + & \\
\hline
\end{tabular}

*0nly units with debitage samples of greater than 50 specimens are included.

Archaic occupations seem to have been concentrated on the terrace point (in Area 2) overlooking both Bowles Creek and the tributary creek which forms the southern boundary of the project area and for a short distance along this tributary creek east of the Bowles Creek bottoms (in the western portion of Area 3 and the southwestern portion of Area 1). As with the ceramics, the lithic artifact densities generally 
decrease to the east in Area 1 (see Table 19) and suggest less intensive occupation (both Archaic and Late Caddoan) away from the terrace edge.

\section{HISTORIC ARTIFACTS}

Included here are 92 artifacts which apparently represent multiple historic occupations (or periods of use) within the project area. The significance of these artifacts is discussed briefly following the category descriptions. Table 18 provides provenience for these specimens.

\section{Glazed Sherds}

Fourteen glazed sherds comprise this category. Seven of these are whiteware with no additional decoration. The remaining seven specimens include six with a blue transfer print and one brown transfer sherd. The brown transfer sherd (from Unit 67) is a small rim fragment with the decoration on the interior. The blue transfer sherds (five from Unit 67 and one from Unit 8) include two rims, three body sherds and one base fragment. Four have both interior and exterior decoration, while the base is decorated on the interior only and one rim sherd has solely exterior decoration.

\section{Glass}

Eighteen pieces of glass were recovered in the excavations. Sixteen are unbleached (clear) glass and appear to represent bottles or other containers. Two specimens, also representing bottles or containers, are manganesebleached (purple) glass. The two latter specimens are from 
TABLE 18

PROVENIENCE OF HISTORIC ARTIFACTS, FLORAL AND FAUNAL REMAINS, AND UNMODIFIED PEBBLES

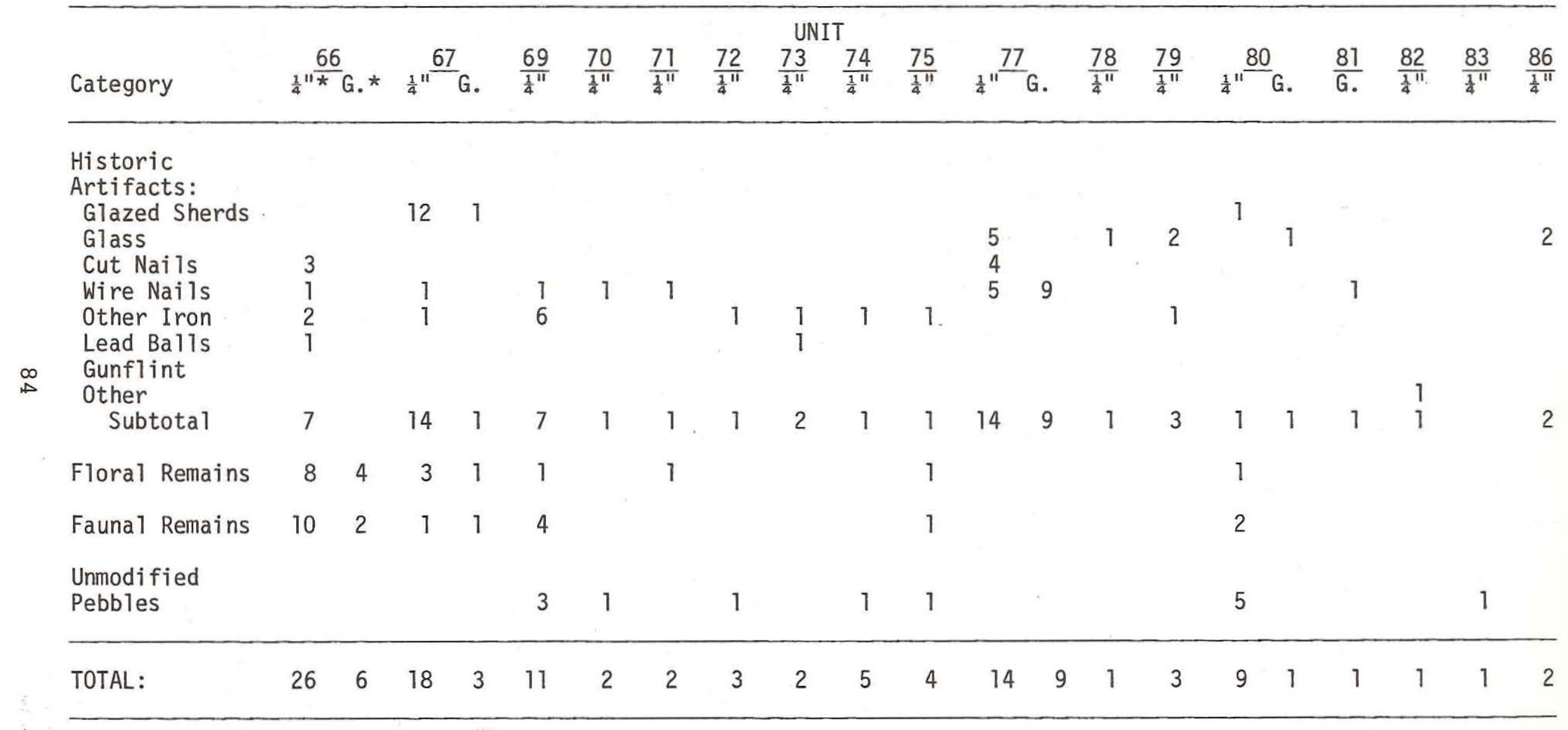

$\star_{\frac{1}{4}} \|=$ screened materia $1 ; G .=$ unscreened general fill. 
TABLE 18, Continued.

\begin{tabular}{|c|c|c|c|c|c|c|c|c|c|c|c|c|c|c|c|c|c|}
\hline Category & $\frac{88}{\frac{1}{4} 11}$ & $\frac{89}{\frac{111}{4}}$ & $\frac{90}{\frac{1}{4}{ }^{11}}$ & $\frac{91}{\frac{111}{4}}$ & $\frac{93}{\frac{1}{4}}$ & $\frac{94^{L}}{\frac{1}{4} " 1}$ & $\begin{array}{l}\text { IT } \\
\frac{96}{\frac{1}{4}}\end{array}$ & $\frac{97}{G .}$ & $\frac{98}{\frac{1}{4} 11}$ & $\frac{99}{\frac{111}{4}}$ & $\frac{100}{\frac{111}{4}}$ & $\frac{101}{\frac{1011}{4}}$ & $\frac{103}{\frac{103}{4}}$ & $\frac{104}{\frac{1}{4}{ }^{11}}$ & $\frac{107}{\frac{111}{4}}$ & $\frac{108}{\frac{111}{4}}$ & Totals \\
\hline $\begin{array}{l}\text { Historic } \\
\text { Artifacts: } \\
\text { Glazed Sherds } \\
\text { Glass } \\
\text { Cut Nails } \\
\text { Wire Nails } \\
\text { Other Iron } \\
\text { Lead Balls } \\
\text { Gunflint } \\
\text { Other } \\
\text { Subtotals }\end{array}$ & 1 & 5 & & 1 & 1 & 1 & 2 & $\begin{array}{l}1 \\
1\end{array}$ & & & & 7 & 1 & & & 2 & $\begin{array}{r}14 \\
18 \\
9 \\
23 \\
23 \\
3 \\
1 \\
1 \\
92\end{array}$ \\
\hline Floral Remains & & & & & & & 10 & & 1 & 2 & & & & 1 & 1 & & 35 \\
\hline Faunal Remains & & & & & & & & & 2 & & & & & & 1 & 1 & 25 \\
\hline $\begin{array}{l}\text { Unmodified } \\
\text { Pebbles }\end{array}$ & & 1 & 1 & 1 & 1 & 6 & 6 & 1 & & & 1 & 6 & & & 2 & 2 & 41 \\
\hline TOTAL: & 1 & 6 & 1 & 2 & 2 & 7 & 18 & 2 & 3 & 2 & 1 & 14 & 1 & 1 & 4 & 5 & 193 \\
\hline
\end{tabular}


Units 78 and 80 .

Nails

Thirty-two nails were recovered. Twenty-three are wire nails, and nine are cut nails.

Other Iron

This category includes 23 iron artifacts other than nails. Fourteen are fence staples (six from Unit 69, three from Unit 101, and one each from Units $66,67,73,74$ and 97); two are pieces of wire (both from Unit 101); one is an iron nut (from Unit 93); two are iron shear pins (both from Unit 101); one is an iron brace (from Unit 66); and the remaining three are unidentifiable iron scraps.

Lead Balls

Included here are three lead balls. Two (one each from Units 73 and 88) are small (7-8 $\mathrm{mm}$ in diameter) and roughly spherical. The third (from Unit 66) appears to be a flattened musket ball.

\section{Gunflint}

A single gunflint was recovered from Unit 91. It is of moderately dark gray chert and is somewhat translucent. Morphologically, it conforms to the description of conventional English gunflints (Harris, Harris, Blaine and Blaine 1965: 343-345) although this specimen has been extensively used and exhibits considerable flaking on all four sides. The identification as English is based on color and the presence of the remnants of two reduction bulbs on the 
FLORAL AND FAUNAL REMAINS

bed surface (Harris, Harris, Blaine and Blaine 1965: 345).

Other

This category consists of a single fragment of a brass strap of unknown function. It is from Unit 82.

\section{Discussion of Historic Artifacts}

The historic artifacts described here relate primarily to twentieth century use of the Davis Site terrace (frequently referred to as Mound Prairie). However, some of these specimens suggest nineteenth and possibly even eighteenth century occupations. Specifically, the blue transfer sherds and the cut nails could easily have resulted from nineteenth century use of the area (see Clark 1980: 4954; Jackson 1977: 51, 77), and the gunflint and musket bal1 may date as early as the late seventeenth century (Clark and Ivey 1974: 68). Considering the absence of historic aboriginal artifacts (especially Patton Engraved pottery) in this collection, it seems likely that the gunflint and musket ball relate to a Euro-American occupation rather than an historic aboriginal one. Table 18 shows that the historic artifacts are widely scattered over the project area but are most dense on the terrace edge overlooking Bowles Creek (in Area 2) and in Unit 77 (Area 1) where two historic features were found.

\section{FLORAL AND FAUNAL REMAINS}

The current excavations yielded a very small collections of plant and animal remains (Table 18). The floral collection consists of 35 fragments of charred hardwood 
nutshel1 Highest frequencies were in Units 66 and 96 which were also areas of high artifact density. Considering this co-occurrence and the presence of charred nutshells in aboriginal contexts in previous excavations, it seems likely that most of these fragments resulted from the aboriginal occupations.

The faunal collection consists of 19 small unidentifiable bone fragments, one deer (Odocoileus virginianus) tooth, one possible cow (cf. Bos Sp.) tooth, two gopher (cf. Geomys Sp.) skulls, one gopher mandible, and one gopher pelvis. All of the identifiable fragments appear to be of recent origin. Most of the unidentifiable specimens are burned and may relate to the aboriginal occupations.

\section{SUMMARY AND CONCLUSIONS}

For four weeks during the spring of 1980, excavations were carried out in a previously uninvestigated portion of the George C. Davis Site (41CE19) in Cherokee County, Texas. The purpose of these investigations was to determine the extent, density and nature of the cultural remains in a 13.62 hectare (33.65 acre) area which is owned by the Texas Forest Service, Indian Mound Nursery, and which is slated for nursery development in the near future." The excavation procedures essentially followed those used in other recent excavations at the site (Fields 1978; Creel 1979; Thurmond and Kleinschmidt 1979) in that power machinery was used to open up excavation units which were then shoveled, troweled and examined for features. Approximately $40 \%$ of the backdirt from most units was screened through one-quarter-inch mesh hardware cloth. 
Forty-two units of varying sizes and totaling 749.31 square meters were completely excavated. This provided a $0.55 \%$ excavated sample of the entire project area. Twentyeight units were scattered across the project area to provide systematic coverage while 14 units were placed in three different areas deemed worthy of more intensive investigation.

In spite of the widespread nature of these excavations, the 1980 field season has provided significant data on the George C. Davis Site. Little was learned about aboriginal features in the project area since few were encountered, but the artifacts collected proved to be revealing.

First, it appears that this portion of the terrace was occupied primarily during the pre-Caddoan and Late Caddoan periods and, to a lesser degree, during the nineteenth and twentieth centuries. There is little evidence that the Alto Focus village area, shown to be so extensive in previous investigations at the site, extended across the Bowles Creek tributary and onto the project area. This is significant in that it delimits one of the boundaries of the poorly-outlined village area.

Second, the occupation of this part of the site appears (not surprisingly) to have been most concentrated in the western and northwestern portions of the project area, along the terrace edge overlooking Bowles Creek, and for a short distance east of the Bowles Creek bottoms along the tributary creek which forms the southern boundary of the project area. Table 19 provides projected artifact densities for all units excavated and demonstrates the dominant trend in artifact distributions. 
TABLE 19

PROJECTED ARTIFACT DENSITIES

\begin{tabular}{|c|c|c|c|c|c|c|c|c|c|}
\hline Unit & $\begin{array}{l}\text { Volume } \\
\text { (m3) }\end{array}$ & $\begin{array}{l}\% \\
\text { Screened }\end{array}$ & $\begin{array}{l}\text { \# of } \\
\text { Ceramics } \\
\text { from } \\
\text { Screening }\end{array}$ & $\begin{array}{l}\text { Projected } \\
\text { Total } \\
\text { Ceramics* }\end{array}$ & $\begin{array}{l}\text { Projected } \\
\text { Ceramic } \\
\text { Density** }\end{array}$ & $\begin{array}{l}\text { \# of } \\
\text { Lithics } \\
\text { from } \\
\text { Screening }\end{array}$ & $\begin{array}{l}\text { Projected } \\
\text { Total } \\
\text { Lithics* }\end{array}$ & $\begin{array}{l}\text { Projected } \\
\text { Lithic } \\
\text { Density** }\end{array}$ & $\begin{array}{l}\text { Projected } \\
\text { Total } \\
\text { Artifact } \\
\text { Density** }\end{array}$ \\
\hline 66 & 8.02 & 40 & 127 & 317 & 39.54 & 573 & 1432 & 178.55 & 226.31 \\
\hline 67 & 7.04 & 40 & 87 & 217 & 30.82 & 203 & 507 & 72.02 & 108.95 \\
\hline 68 & 11.15 & 40 & 9 & 22 & 1.97 & 158 & 395 & 35.43 & 37.40 \\
\hline 69 & 9.04 & 40 & 33 & 82 & 9.07 & 334 & 835 & 92.37 & 105.09 \\
\hline 70 & 4.98 & 40 & 1 & 2 & 0.40 & 10 & 25 & 5.02 & 6.02 \\
\hline 71 & 5.69 & 40 & 77 & 192 & 33.74 & 22 & 55 & 9.67 & 44.29 \\
\hline 72 & 3.64 & 40 & 164 & 410 & 112.64 & 77 & 192 & 52.75 & 166.76 \\
\hline 73 & 1.04 & 35 & 5 & 14 & 13.46 & 38 & 109 & 104.81 & 124.04 \\
\hline 74 & 6.67 & 40 & 2 & 5 & 0.75 & 16 & 40 & 6.00 & 8.25 \\
\hline 75 & 5.71 & 40 & 140 & 350 & 61.30 & 86 & 215 & 37.65 & 100.18 \\
\hline 76 & 8.97 & 15 & 0 & 0 & 0 & 2 & 13 & 1.45 & 1.45 \\
\hline 77 & 4.01 & 40 & 0 & 0 & 0 & 10 & 25 & 6.23 & 14.96 \\
\hline 78 & 3.78 & 35 & 6 & 17 & 4.50 & 17 & 49 & 12.96 & 18.25 \\
\hline 79 & 4.19 & 50 & 23 & 46 & 10.98 & 68 & 136 & 32.46 & 44.87 \\
\hline 80 & 8.78 & 50 & 404 & 808 & 92.03 & 483 & 966 & 110.02 & 203.19 \\
\hline 81 & 6.05 & 20 & 0 & 0 & 0 & 9 & 45 & 7.44 & 7.44 \\
\hline 82 & 6.34 & 20 & 0 & 0 & 0 & 11 & 55 & 8.68 & 9.46 \\
\hline 83 & 4.51 & 22 & 0 & 0 & 0 & 57 & 259 & 57.43 & 57.43 \\
\hline 84 & 6.93 & 25 & 0 & 0 & 0 & 8 & 32 & 4.62 & 4.62 \\
\hline 85 & 5.52 & 40 & 5 & 12 & 2.17 & 32 & 80 & 14.49 & 16.67 \\
\hline 86 & 6.33 & 25 & 13 & 52 & 8.21 & 24 & 96 & 15.17 & 24.01 \\
\hline 87 & 2.99 & 40 & 18 & 45 & 15.05 & 111 & 277 & 92.64 & 107.69 \\
\hline 88 & 3.65 & 40 & 16 & 40 & 10.96 & 138 & 345 & 94.52 & 106.03 \\
\hline
\end{tabular}

*Projected artifact totals derived by multiplying number of artifacts from screening by 100 and then dividing by the screening percentage.

**Projected artifact densities = projected total artifacts $/$ volume ( \# of artifacts $/ \mathrm{m}^{3}$ ). 
TABLE 19, Continued.

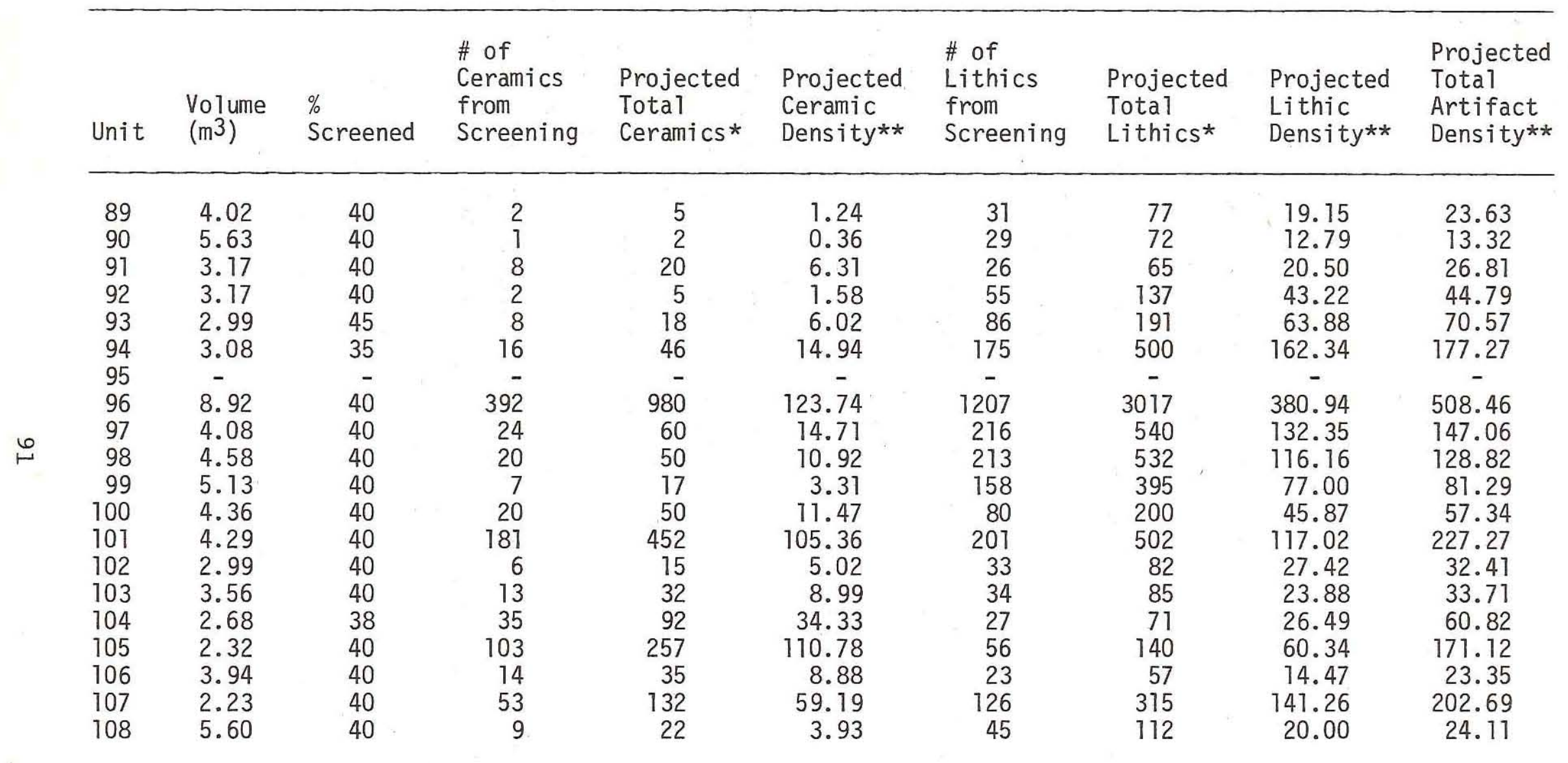


Third, the artifacts suggest that the Archaic and Caddoan occupations were distributed somewhat differently within the project area. The Caddoan occupation appears to have been oriented towards the terrace edge overlooking Bowles Creek while the Archaic occupation was oriented towards the terrace edge overlooking both Bowles Creek and the tributary creek, and for a short distance along the tributary creek east of the Bowles Creek bottoms. The reasons for these differing preferences are unknown.

Even though the Spring 1980 excavations have provided important temporal and spatial data, it is felt that these investigations have certain shortcomings. Specifically, the brevity of the field season precluded the extensive excavations necessary to determine the internal structure of this portion of the site. It is therefore recommended that the Texas Antiquities Committee reserve the management area containing the greatest density of cultural remains (Area 2) from nursery development. Despite the efforts of many people, there is no guarantee that this part of the site (Area 2) will undergo further investigations. Should this area be ignored, a significant portion of the prehistory of the Davis Site may never be understood. The stringently limited time allowed for analysis and write-up has prevented the detailed analysis which this collection deserves. Certainly, it is hoped that the data presented here in raw form can and will be used by other researchers; however, it is felt that the materials collected could profit from re-analysis when specific research questions are addressed in the future. 
REFERENCES CITED

Clark, John W., Jr.

1980 The Woodlands: Archeological Investigations at the Sam Houston Home, Huntsville, Walker County, Texas. Reports of Investigations, Number 4, Prewitt and Associates, Inc., Austin, Texas.

Clark, John W., Jr. and James E. Ivey

1974 Archeological and Historical Investigations at Martin Lake, Rusk and Panola Counties, Texas. Research Report No. 32, Texas Archeological Survey, The University of Texas at Austin.

Creel, Darrell

1979 Archeological Investigations at the George C. Davis Site, Cherokee County, Texas, Summer 1978. Manuscript of report in preparation.

Duffield, Lathel $\mathrm{F}$.

1963 The Strawn Creek Site: A Mixed Archaic and NeoAmerican Site at Navarro Mills Reservoir, Navarro County, Texas. Report submitted to the National Park Service by the Texas Archeological Salvage Project, The University of Texas, Austin.

Fields, Ross

1978 Report on the 1977 Investigations at the George C. Davis Site, Caddoan Mounds State Historic Site, Cherokee County, Texas. Report submitted to the Texas Parks and Wildlife Department by the Texas Archeological Research Laboratory, The University of Texas at Austin.

1979 Cultural Resources of the Davy Crockett, Sam Houston, Angelina, and Sabine National Forests of Texas. Report submitted to the United States Forest Service by the Texas Archeological Research Laboratory, The University of Texas at Austin.

Harris, R. K., Inus Marie Harris, Joy C. Blaine, and Jerrylee Blaine

1965 A Preliminary Archeological and Documentary Study of the Womack Site, Lamar County, Texas. Bulletin of the Texas Archeological Society 36: 287-364.

Jackson, Marsha F.

1977 Texana: Excavations at a 19th Century Inland Coastal Town, Jackson County, Texas. Research Report No. 56, Palmetto Bend Reservoir Series, Volume I, Texas Archeological Survey, The University of Texas at Austin. 
Jelks, Edward B.

1965 The Archeology of the McGee Bend Reservoir, Texas. $\mathrm{Ph} . \mathrm{D}$. dissertation, The University of Texas at Austin.

Newell, H. Perry and Alex D. Krieger

1949 The George C. Davis Site, Cherokee County, Texas. Memoirs of the Society for American Archaeology No. 5. Menasha.

Prewitt, Elton R.

1974 Upper Navasota Reservoir: An Archeological Assessment. Research Report No. 47, Texas Archeological Survey, The University of Texas at Austin.

Shafer, Harry J.

1973 Lithic Technology at the George C. Davis Site, Cherokee County, Texas. Ph.D. dissertation, The University of Texas at Austin.

1975 Comments on Woodland Cultures of East Texas. BulZetin of the Texas Archeological Society 46: 249-254.

Spock, Carolyn

1977 An Analysis of the Architectural and Related Features at the George C. Davis Site. M.A. thesis, The University of Texas at Austin.

Story, Dee Ann

1972 A Preliminary Report on the 1968, 1969, and 1970 Excavations at the George C. Davis Site, Cherokee County, Texas. A mimeograph report submitted to the Office of the State (Texas) Archeologist and the National Science Foundation.

Story, Dee Ann and S. Valastro, Jr.

1977 Radiocarbon Dating and the George C. Davis Site, Texas. Journal of Field Archaeology 4(1): 63-89.

Suhm, Dee Ann and E. B. Jelks

1962 Handbook of Texas Archeology: Type Descriptions. Texas Archeological Society Special Publication No. 1, and the Texas Memorial Museum, Bulletin No. 4. Austin.

Thurmond, J. Peter and Ulrich Kleinschmidt

1979 Report on the Fall 1978 Investigations at the George C. Davis Site, Caddoan Mounds State Historic Site, Cherokee County, Texas. Report submitted to the Texas Parks and Wildlife Department by the Texas Archeological Research Laboratory, The University of Texas at Austin. 